Bengali Harlem and the Lost Histories of South Asian America 



\title{
Bengali Harlem and the Lost Histories of \\ South Asian America
}

\author{
Vivek Bald
}


Copyright (C) 2013 by the President and Fellows of Harvard College All rights reserved

Printed in the United States of America

Library of Congress Cataloging-in-Publication Data

Bald, Vivek.

Bengali Harlem and the lost histories of South Asian America / Vivek Bald.

p. $\mathrm{cm}$.

Includes bibliographical references and index.

ISBN 978-0-674-06666-3

1. South Asian Americans-History-20th century. 2. South Asian Americans-

Cultural assimilation. 3. Muslims-United States-History-2oth century.

4. Working class-United States-History—2oth century. 5. Haidar, Dada Amir.

6. United States-Race relations-History-20th century. 7. Harlem(New York, N.Y.)-

Race relations-History-2oth century. 8. United States-Emigration and immigration-History-2oth century. 9. South Asia-Emigration and immigrationHistory-20th century. I. Title.

$$
\begin{gathered}
\text { E184.S69B35 } 2012 \\
305.891^{\prime} 4073-\mathrm{dc} 23 \\
2012022231
\end{gathered}
$$


For my daughter. 



\section{Contents}

Author's Note ix

Introduction: Lost in Migration $\quad 1$

1. Out of the East and into the South 11

2. Between Hindoo and Negro 49

3. From Ships' Holds to Factory Floors 94

4. The Travels and Transformations of Amir Haider Khan 137

5. Bengali Harlem 160

6. The Life and Times of a Multiracial Community 189

Conclusion: Lost Futures $\quad 215$

List of Abbreviations 231

Notes 233

$\begin{array}{ll}\text { Acknowledgments } & 277\end{array}$

Index $\quad 283$ 



\section{Author's Note}

Lthough many of the people about whom I have written came
from regions that are now part of the nations of Bangladesh and Pakistan, most of the period covered here pre-dates the creation of those nations. When I am writing about the pre-1947 period, I have chosen to refer to these individuals as Indian and their place of origin as India in order to maintain historical accuracy. I use the term South Asian when referring either to the post-1947 period or to a stretch of time that includes both the pre- and post-1947 periods. I use the term Bengali to refer to many of the individuals who appear in this book in order to specify their origins in the larger region of Bengal, both West (in present-day India) and East (in present-day Bangladesh). To many of these migrants, regional (Bengali) and sub-regional (e.g.: Sylheti) identity appears to have been more salient on a day-to-day basis than any national identification.

The research for this book entailed piecing together archival documents - ship manifests; census enumerations; birth, death, and marriage certificates - in which British and U.S. officials transliterated South Asian names in multiple ways. The migrants whose lives and travels are recorded in these documents also likely used different English spellings of their names at different times. In the interest of clarity, I have standardized my spelling of specific individuals' names within the text of the 
book. I have generally chosen the spelling that appears most frequently in the archives or the name that the individual appears to have settled on in his own daily life in New Orleans, Harlem, or elsewhere. These spellings often take forms that might be considered unorthodox by contemporary South Asian readers (e.g., Ally, Fozlay, Surker, Raymond, Box). When I refer to specific archival documents in the footnotes, I use the spellings that appear in those original documents.

I named this project "Bengali Harlem" early on in its development, when it focused primarily on a set of interconnected families of Bengali ex-seamen who had settled and intermarried in Harlem. At that time, the title was literal, referring to a particular set of people in a particular place. Over several years of research, as I followed an expanding trail of archival documents, the history I was piecing together grew far beyond Harlem and it grew to include many other people who were not Bengali-from the Kashmiri seaman and activist Dada Amir Haider Khan to Creole, African American, and Puerto Rican women. Over time, the name has become metaphorical rather than literal, standing for a particular set of encounters and possibilities tied to South Asian life making and place making in U.S. neighborhoods of color. 
Each and every identity is extended through a relationship with the Other.

Édouard Glissant, Poetics of Relation 



\title{
Introduction
}

\author{
Lost in Migration
}

T March of 1945, two men from India led testimony before the House Committee on Immigration and Naturalization of the U.S. Congress. ${ }^{1}$ One was a Muslim who had settled in Arizona's Salt River Valley in the 1910s, where a handful of farmers from the subcontinent had turned hundreds of acres of land toward the production of rice. ${ }^{2}$ The other was a Punjabi Sikh entrepreneur who came to New York City in 1926 and established a business supplying luxury Eastern imports to the city's elites. ${ }^{3}$ Both men were lobbying Congress to make East Indians eligible for U.S. citizenship. Their task was not an easy one. In the early years of the twentieth century, Indian immigrants had been vilified. When hundreds of Punjabi workers began to arrive in California and the Pacific Northwest around 1904, they found white citizens' groups and labor unions already lined up against them, emboldened by years of targeting immigrants from China and Japan. The nativists focused their vitriol on the Indian newcomers, whipping up a moral panic over what they called the "tide of turbans" that threatened to swamp white America. At times, the xenophobia boiled over into violence; in September 1907, a mob of white lumber-mill workers rampaged through the northwestern town of Bellingham, Washington, attacking Indian migrants indiscriminately, rounding them up and forcing them from 
their jobs and homes. ${ }^{4}$ By 1917 , the federal government had passed legislation barring Indians and virtually all other Asians from entering the United States. The 1917 Immigration Act made East Indians equivalent in the eyes of the law to alcoholics, "professional beggars," and the insane; all were undesirable aliens, to be turned away at the borders. In 1923, the U.S. Supreme Court added a further layer to the exclusion regime by ruling that those East Indians who were already resident in the United States were racially ineligible to become U.S. citizens. Not only had Indians been cast as undesirable, but they had been made permanent outsiders. For the next twenty years, it remained this way: Indians were prevented from immigrating to the United States, from owning land, from voting, and from naturalizing-from becoming an accepted part of the nation. ${ }^{5}$

Mubarek Ali Khan and J. J. Singh sought to change this status quo, and as they stood before the Committee on Immigration and Naturalization, the two Indian lobbyists could not have seemed more different. Khan was a graying middle-aged man who wore spectacles, plain suits, and a cap that marked his Muslim faith. At six feet, J. J. Singh towered over Khan. He was in his late forties, handsome, self-assured, and polished in both demeanor and appearance. He had short hair and was clean shaven, having dispensed with his turban and beard after settling in the United States, and he favored fine suits. ${ }^{6}$ The two men had been lobbying Congress over several sessions, each advocating a different approach to redressing Indian exclusion. Khan's proposed legislation was focused and practical; it sought naturalization rights for the roughly three thousand Indians who were estimated to have settled in the United States prior to the Supreme Court decision of 1923. Most of these immigrants were farm and factory laborers-exactly the population of "undesirable aliens" that the 1917 Immigration Act had sought to keep out of the country. However, the three thousand had now been living and working in the United States continuously for more than twenty years, and Khan's bill began from an assertion that they were already Americans in every sense but the law. Singh's bill was more extensive and more ambitious. It would repeal the very logic of exclusion, making Indians racially eligible to become U.S. citizens, and it would create a quota allowing one hundred Indians per year to naturalize. His legislation, however, was focused pri- 
marily on the future; it would favor new, and presumably more highly qualified, immigrants over pre-1923 settlers, reserving seventy-five of each year's naturalizations for such applicants. ${ }^{7}$

As different as the two bills were, Khan and Singh and their respective supporters had come to lean on similar arguments when they went before Congress. Both men's camps bolstered their cases for repeal of the naturalization laws by stressing the accomplishments of "leading" Indian Americans of the day, and each presented lists and biographies of these scientists, engineers, and scholars. Such individuals, they argued, were wronged by the current laws; they were prevented from becoming American citizens even though they had contributed their considerable knowledge and expertise to the United States. Khan also stressed the injustice suffered by large-scale Indian farmers, like those in Arizona, who could not own the land they had made productive. Singh spoke of the Indian businessmen who could not do meaningful business in the United States because they were restricted to short-term tourist visas. Both sides stressed the participation of Indian forces and Indian men in the war effort and touted the benefits of expanded U.S. trade with an India that would likely gain its independence at the war's end. ${ }^{8}$

The majority of Indians who were living in the United States in 1945 and who were being prevented from becoming U.S. citizens were, in fact, not scientists, not businessmen, not engineers, scholars, or even large-scale agriculturalists. They were farm laborers and industrial and service workers. But in the 1945 hearing, this was mentioned only sporadically and often obliquely. Even Mubarek Ali Khan, who represented this group, was cautious in how he described "the three thousand." J. J. Singh made a few references to the farm and factory workers, but always in the negative: that is, he assured the committee that because his bill required that most of the one hundred naturalizations per year be filled by Indians from India (rather than by those already living in the United States) his legislation would not result in a flood of Indian workers becoming U.S. citizens. Acknowledging that some congressional committee members were still "worried about the so-called laboring classes," Singh went so far as to assure them that "with the industrialization schemes that are afoot in India, I do not anticipate that [any workers] would care to leave India" to come to the United States. ${ }^{9}$ As the hearings 
progressed, no one seemed willing to speak boldly for the silent majority of Indians in the United States, for a shadow population of migrants, spread across the country, who had dropped "out of status" as the immigration laws changed around them. No one, that is, except a Bengali from New York City named Ibrahim Choudry.

Choudry was a former director of an Indian merchant sailors' club in Manhattan and seaman turned community activist, secretary of the India Association for American Citizenship. Although allied with Mubarek Ali Khan, he was willing - and likely felt bound-to be more forceful than Khan in his advocacy. In the midst of the March 1945 hearings before the Committee on Immigration and Naturalization, a letter that Choudry had written was introduced into testimony. There is no indication that it was read aloud, which likely means that it was simply handed by Khan to the appropriate clerk to be added to the typed record after the conclusion of the hearing. Shuffled into archival obscurity, Choudry's letter spoke up unequivocally for a population that other witnesses were less forthright in acknowledging. "I do not speak . . . here for the few," Choudry wrote:

I speak for the many. I am not speaking for the transient elementthe student the business man, the lecturer, the interpreter of India's past and present, whose interests and ties in this country are temporary, the man or the woman whose roots are in India and who eventually returns home. I talk for those of us who, by our work and by our sweat and by our blood, have helped build fighting industrial America today. I talk for those of our men who, in factory and field, in all sections of American industry, work side by side with their fellow American workers to strengthen the industrial framework of this country.... We have married here; our children have been born here. ... I speak for such as myself, for those of my brothers who work in the factories of the East and in Detroit. ... I speak for the workers and the farmers of our community whose lives have been bound to this country's destiny for 23 years or longer. I speak for these men who while they themselves have no rights under oriental exclusion have seen their sons go off to war these last years to fight for a democracy which they-their fathers-could not them- 
selves enjoy. I speak for men who ... expect to die in the country to which they have given their best years. ... [W]e simply ask you for justice-American justice. ${ }^{10}$

Despite his eloquence, Choudry was on the losing side of U.S. immigration history. Although the naturalization bill that President Harry S. Truman signed into law in July 1946 did make all Indians already resident in the country eligible for citizenship, the law was grounded in the ideas that J.J. Singh and his allies had championed and to which Mubarek Ali Khan had largely assented. These ideas-that U.S. immigration policies toward India should favor scientists, engineers, and businesspeople and be driven by national considerations of trade and foreign policynot only won out in 1946 but were eventually enshrined in the Hart-Celler Act, ${ }^{11}$ which opened the door to tens of thousands of skilled professionals from the subcontinent in 1965. These are the South Asian immigrants whom Americans would come to know in the 1970s, 1980s, and 1990s - the doctors, the engineers, the entrepreneurs. While it seemingly put an end to the exclusion era, the 1965 act essentially maintained the exclusion of working-class immigrants. Choudry's letter is like a flash in the midst of this history. For a brief moment, it revealed a hidden population of Indian laborers who had no legal status but who by the mid1940 s had already long become part of the fabric of U.S. society, living, working, and bringing up families in the shadows of its restrictive antiAsian immigration laws. The ex-seaman from New York had attempted to bring these men out into the open, to lay claim, on their behalf, to official belonging in the U.S. nation.

In the years since, the migrants for whom Choudry spoke have passed away, and as their stories have disappeared from public memory, we have been left with a history that is fragmentary and partial. The fullest narrative we have of an early South Asian presence in the United States is that of Punjabi migrants to the Canadian and U.S. West Coast. Between 1904 and 1924, these predominantly Sikh workers entered Vancouver, were driven southward into the Pacific Northwest by Canadians" "whites only" policy, encountered outbreaks of racial violence after entering the lumber mills of Washington and Oregon in the early 1900s, and then made their way into the rich agricultural areas stretching along inland 
California to the Mexican border and the U.S. Southwest. For more than three decades, scholars have explored Punjabi migrants' experiences, building a rich understanding of their encounters with local populations; their involvement in the expatriate anticolonial Ghadar movement; and their attempts to fight the imposition of anti-Asian immigration, naturalization, and landownership laws. ${ }^{12}$ But we have come to understand this West Coast history as if it were the full story of early South Asian America and we have too often assumed that the story came to a definitive end when the 1917 Immigration Act criminalized Asian immigration and the 1923 Supreme Court decision in United States $v$. Bhagat Singh Thind closed off the pathway to citizenship. As a result, thousands of South Asian migrants who settled across other parts of the country - the East Coast, the South, the Midwest-and who either arrived or stayed in the United States under the radar of racist immigration laws, have been lost to history. Their lives have remained hidden in disparate archives and fading family memories.

Ibrahim Choudry was one of these migrants. He was part of a phenomenon that has gone unaccounted for in both popular and scholarly accounts of Asian immigration to the United States. Beginning around the time of the First World War, hundreds of Indian maritime workers, men who labored in the engine rooms and kitchens of British steamships, escaped into the crowded waterfronts of New York, Philadelphia, and Baltimore in search of less brutal and captive work and better wages onshore. These men were predominantly Muslims from rural backgrounds. The largest number were from villages in East Bengal-a region that would later become the nation of Bangladesh. Others hailed from regions that are part of present-day Pakistan-Punjab, Kashmir, and the Northwest Frontier. After signing on to ships in Calcutta and Bombay, they worked under indenture-like conditions at the mercy of British ships' masters for months and years at a stretch. During the war, however, these men found that their labor was in demand in U.S. steel, shipbuilding, and munitions industries, and they formed clandestine networks to help one another jump ship and make their way inland to factory towns. Their networks helped sustain an Indian presence onshore even after the passage of the 1917 Immigration Act, so that by the 1920s, Indian workers could be found across the whole of the U.S. industrial 
belt. In New York City, the largest port of entry for this population, exseamen also entered the service economy. They lived in shared apartments near the west-side waterfront and on the Lower East Side, and worked as line cooks, dishwashers, doormen, and elevator operators in Manhattan restaurants and hotels.

This was by and large a transient population. Over time, hundreds of Indian seamen cycled through the networks that their co-workers and kin had first set up in the 1910s, and most eventually returned to the maritime trade and the subcontinent. But some stayed in the United States for good. By the time Ibrahim Choudry made his petition to Congress, he and other ex-seamen were part of a population of Indian workers that had put down roots throughout the U.S. Northeast and Midwest. Denied official belonging, they became part of another nation, a nation beneath the nation, in working-class neighborhoods of color from New York to Baltimore to Detroit. The greatest number appear to have settled in Harlem. Many married local women here, had children, and even as they maintained ties to one another, developed Puerto Rican, African American, and West Indian extended families and friends. Some opened restaurants or started small businesses, and as they settled, they became a quiet but integral part of the daily life of their adopted neighborhood. ${ }^{13}$

Astonishingly, this community had an even earlier precedent. In the 1880 s, groups of Bengali Muslim peddlers from the present-day Indian state of West Bengal had begun making their way to and through the United States. These men brought embroidered silks and other "exotic" goods to sell to an American public that was in the grips of a fashion for all things "Indian" and "Oriental." As hundreds of these peddlers followed the pathways of U.S. leisure travelers and consumers, their trajectory took them to the beach boardwalks of New Jersey, the streets of southern cities, and the emerging Euro-American tourist destinations of the Caribbean and Central America. At the U.S. border, they faced a restrictive immigration regime, focused most pointedly on the exclusion of Chinese labor migrants but increasingly suspicious of and hostile toward "Asiatics" in general. Once inside, they found a United Statesnorth and south - that was riven by racial segregation; the subordinate social status of African Americans was delineated in the geography of 
the cities and towns to which they came, and was enforced by law, custom, and violence. As dark-skinned men from "the East," the peddlers occupied a slightly different position, but one that was inconsistent and unpredictable; while their place within the country's black-white racial imagination was not quite fixed, and to a degree was even manipulable, their place on the streets and within the residential neighborhoods of segregated cities was much clearer. So, as they accessed white consumers with fantasies of India, their pathway into and across the United States was a pathway through working-class black neighborhoods; they established outposts in these places and then moved outward to sell their goods.

The most important neighborhood to their operation was New Orleans' Tremé. Here, some of the Bengalis married and started families with African American women, who were part of recent black migrations into the city, or with Creole of Color women who had deep generational roots in Tremé. These local women of color became as important to the operations of the network as the women who remained in West Bengal villages; while Bengali women produced the embroidered goods that would be sold in the United States and tended to the homes, land, and families that the peddlers left behind for months or years at a time, women in New Orleans helped Indian men settle and establish themselves locally; they gave the peddler network stability and longevity. ${ }^{14}$ Between the 1890 s and 1920s, hundreds of Bengali peddlers were thus able to cycle through to sell their wares. After the network ceased to operate, a small number of the men stayed behind, and in the ensuing years, they, their wives, their children, and their descendants became part of the history of black New Orleans.

The stories of these Muslim peddlers and seamen from colonial India are as remarkable as they are unknown. They are remarkable for what the men had to navigate, for the places they ended up, and for the kinds of communities and families they formed once they reached the United States. They defy most assumptions and expectations about South Asian migration to the United States - about who South Asian migrants are, where they come from, what trajectories they follow, how they navigate the U.S. landscape of race and class, and how they assimilate. In fact, these stories force us to reconsider some deep-held beliefs 
about U.S. immigration. The Indian Muslim migrants of the late nineteenth and early twentieth centuries did not experience the welcome that was promised to the world's "tired . . p poor . . . huddled masses." Most came with no expectation that they would stay; they did not come, in historian Sucheta Mazumdar's words, as "part of incipient settler families clutching a one-way ticket in their hands and the American Dream in their hearts." These men were sojourning laborers, or what we now would understand more broadly as global labor migrants. They were among the many populations of peasants and workers whose traditional means of livelihood had been disrupted by colonization, industrialization, and the mechanization of agriculture, and who traveled across oceans to access the jobs and markets available in the United States. As such, the peddlers and seamen illuminate the larger displacements and mass migrations that characterized their era. ${ }^{15}$ At the same time, they point to one of the United States' most enduring contradictions: in the very years that the United States became what its leaders would later call a "nation of immigrants" it also became a nation of immigrant exclusion. ${ }^{16}$

These Indian migrants provide us with a different picture of "assimilation." The peddlers and seamen did not form ethnic enclaves, as did Italians, Greeks, Germans, or, for that matter, South Asian immigrants of later generations. Nor did they follow the iconic path of immigrant upward mobility that would lead so many members of these other groups out of their ethnic enclaves into predominantly white suburbs. The networks that Indian Muslims formed-networks that were embedded in working-class Creole, African American, and Puerto Rican neighborhoods and entwined with the lives of their residents-represent a different pathway into the United States. All of the places where the peddlers and seamen put down roots-and Harlem more than any other-were receiving-stations for migrants and immigrants of color, particularly those displaced by white-supremacy in the U.S. South, and the military and economic pursuits of Britain and the United States in the Caribbean. These were as much spaces of the global black diaspora as they were neighborhoods of the United States.

It was here that South Asian Muslims were able to forge complex and syncretic new lives and build multi-ethnic families and communities at a 
time when the U.S. nation saw them only as aliens and criminals. And they were not alone in this; South Asians were just one of several smaller groups - many living under the radar of the immigration laws-who found homes and built lives in these places. They included Chinese, Filipinos, and Arabs in Tremé; Filipinos, Chinese, and Roma in West Baltimore; Arabs, Afghans, and Greeks in Black Bottom; Mexicans, Argentines, and Peruvians in Harlem, among others. ${ }^{17}$ The stories of the men who were described in Mubarek Ali Khan's legislation simply as "three-thousand Eastern Hemisphere Indians," thus tell us a great deal about U.S. neighborhoods and communities of color in the first half of the twentieth century-about their heterogeneity, their openness, and the unacknowledged role they played in U.S. immigration history. 


\section{Out of the East and into the South}

There are some thirty Indians, fresh from East India who landed in Atlanta about two weeks ago and every one of them has been peddling notions in and around the city.

-Atlanta Constitution, November 21, 1912

E LLIS ISLAND WAS ON FIRE. The grand, three-story immigration station had cost more than $\$ 75,000$ and had taken almost two years to build. It had been in operation for no more than five and a half years, and now, in the middle of the night of June 15, 1897, a fire had broken out. More than two hundred immigrant detainees were rushed out of the building as the flames spread. Across the water, on the southern tip of Manhattan, fire crews scrambled into action, but before their boats could reach the island, the entire pine structure was engulfed in smoke and fire; the ceiling quickly caved in and the federal government's flagship immigrant-processing station collapsed to the ground.

Three days later, the SS St. Louis sailed into New York Harbor from Southampton, England. It was a beautiful early summer evening; the sky was clear and the weather was warm. The St. Louis approached the Statue of Liberty, still a relatively new addition to the waters below Manhattan, and turned gently to the left toward the mouth of the North River. Twelve Muslim men from Calcutta and Hooghly, West Bengal, were on board the steamship, preparing to disembark after their six-day journey across the Atlantic. Ahead and to the ship's right, they would have seen southern Manhattan's impressive outcrop of skyscrapers-the tallest reaching more than twenty stories above the ground-aglow in 
the evening sun. On their left, where their ship was supposed to dock, lay a pile of rubble.

Since the conflagration, the Bureau of Immigration had been scrambling to deal with incoming passenger ships. Each day, two or three more ships arrived, bearing thousands of immigrants from Europe and points farther east. In the absence of a processing facility, the Bureau had ordered arriving steamships to proceed to their respective piers along the Manhattan waterfront. A team of medical and immigration inspectors would meet each ship as it docked, examine its passengers, and admit or detain them as warranted. So, after passing the embers of Ellis Island, the St. Louis made its way up the North River to Pier 14, the terminal for its parent company, the American Line. This was one of the largest and most modern structures on the waterfront, extending into the river from West Street between Fulton and Vesey, exactly where, a century later, the north tower of the World Trade Center would stand. ${ }^{1}$

The Bengali men on board the St. Louis were peddlers, on their way to the beach resorts of New Jersey-Atlantic City, Asbury Park, and Long Branch. In their home villages, their wives, mothers, sisters, and daughters produced finely embroidered silk and cotton fabrics-handkerchiefs, bedspreads, pillow covers, and tablecloths-in a style known as chikan; no doubt, the luggage that each man carried was filled with such goods. At some point earlier in the year, perhaps as recently as May, the twelve men had made their way by ship from Calcutta to Southampton, England. They had then crossed the Atlantic in the SS St. Louis, with more than two hundred other migrants, immigrants, and travelers. They shared the cramped quarters of third class with a German butcher, an Armenian student, a Japanese cook, two Russian Jewish tailors, and a number of returning Americans: a dressmaker, a cigar worker, a cattleman, an upholsterer. More than half the passengers were Scandinavian immigrants on their way to New York, Pennsylvania, Illinois, Minnesota, and North Dakota. The majority of these men and women were farmers, laborers, and domestic workers. ${ }^{2}$

What were the Bengali peddlers anticipating as their ship docked on West Street? The older members of the group, Mintoz Mondul, Moksad Ali, and Moosha Mondul, had been making voyages to the United States since the 1880 s. In those early years, they had been through immigration 
procedures at Manhattan's Castle Garden depot, and they may have seen the Ellis Island station under construction, sailing past it on their way in and out of port. In more recent years, a few of the peddlers had passed through Ellis Island's imposing new processing facility and made their way through its maze of metal pens, going from one type of inspection to the next. ${ }^{3}$ It is hard to know whether these previous experiences would have eased the Bengalis' anxiety as they approached Pier 14 or increased it. The men likely knew what to expect as they faced the indignity of the medical exam, in which they were poked and prodded like cattle, their hair combed through for lice, their eyelids pulled back with a metal hook to check for trachoma. However, the number of questions that the immigration examiners asked them had been increasing and the speed at which they were asked these questions had grown more rapid. And in the days following the Ellis Island fire, the examiners were, no doubt, under pressure to be extravigilant, to prove that the adverse conditions would not hamper their ability to prevent "undesirable aliens" from entering the country. ${ }^{4}$

When Mintoz and Musa Mondul, Moksad Ali, their colleagues Abdul Aziz, Abdul Ahmed, Basiruddin, Obidullah, and Fazleh Rahman, and the rest of their group went up before the examiner, they gave a single set of answers to a quick succession of questions: Occupation? Merchant. Nationality? East Indian. Last residence? Southampton. Final destination? New Jersey. Who paid for your ticket? Myself. How much money do you have with you? £6. Been in the United States before? Yes. Joining a relative? No. Been in prison? No. Polygamist? No. Under contract to work in the United States? To this last question, they all answered "no" - or at least this is what was recorded on the incoming ships' manifest. But something must have happened when the men were face-to-face with the immigration examiner. Something was said; something was misunderstood; someone hesitated; or the examiner simply decided that the dozen Indians were suspicious, that they looked like contract workers, entering the country in violation of the law. He ordered them detained. As the Scandinavian farmers and workers disembarked onto West Street to start new lives, meet eagerly waiting relatives, or make their way to points farther west, the twelve Muslim peddlers from Bengal were taken away to the southern tip of Manhattan, to a 
makeshift detention center on the top floor of the Barge Office-a facility that one contemporary reporter described as "grimy, gloomy, [and] more suggestive of an enclosure for animals than a receiving station for prospective citizens." Across the water, a few miles down the New Jersey coast, the beach boardwalks were filling up with thousands of summer vacationers, thousands of potential customers for the "fancy goods" that sat packed away in the peddlers' trunks. But this summer's trip was not to be. After holding them in detention for eight days, the Bureau of Immigration's Board of Special Inquiry ordered the twelve men deported, declaring that "inasmuch as they peddle goods not their own, they are held to come under provisions of the Contract Labor law." On the ship that took them back to London, the men were now listed as "laborers" rather than "merchants."

What is remarkable about this story is not the harshness of the treatment to which the twelve Bengali peddlers were subjected-or the cursory nature of the Board of Inquiry hearing that turned them back from U.S. shores. In the closing years of the nineteenth century, as the numbers of immigrants arriving at U.S. ports swelled, the federal government had taken over the processing and evaluation of arriving passengers-a role previously played by individual states. The government's Immigration Bureau began rationalizing, regularizing, and tightening the criteria according to which "alien passengers" would be admitted. The Chinese Exclusion Act of 1882 and the Alien Contract Labor Law of 1885 were two of the first elements of the new border regime. Both were suffused with racist assumptions about the nature of Asian laborers, and both complicated the Bengali peddlers' ability to cross into the United States, making their treatment in 1897 , at the very least, unsurprising. ${ }^{6}$ What was remarkable was the peddlers' ability to adapt to their deportation and operate within a much larger field of possibilities. Within a month of their arrival in London, five of the deported men-Musa Mondul, Basiruddin, Abdul Aziz, Abdul Ahmed, and Obidullah-signed on with a group of fifty miners from England, Scotland, Ireland, and Northern and Eastern Europe and set off by steamer for South Africa, which, along with Australia, was another market for their goods. ${ }^{7}$ Within a year or two, almost all twelve men would return to the United States, traveling in smaller 
groups, trying different ports, finding a way to get back in, reunite with kin and co-villagers, and carry on their work.

These men were part of what may be the first significant settlement of South Asians in the United States. Beginning sometime in the 1880 s, Muslim peddlers from a cluster of villages just north of Calcutta began traveling to the United States to sell "Oriental goods"-embroidered cotton and silk, small rugs, perfumes, and a range of other items. Indian demand for their handicrafts had declined under colonial rule, as the British imported cheap factory-made textiles and established greater control over the subcontinent's internal markets. ${ }^{8}$ But overseas, middle-class consumers in Britain, Australia, South Africa, and the United States were in the midst of a fin de siècle fashion for the exotic ideas, entertainments, and goods of India and "the East." Other Indian traders had made their way outward from the subcontinent to sell handicrafts to European travelers in the Mediterranean and North Africa. ${ }^{9}$ The Bengalis ventured into new territories, establishing an extensive network that stretched through the East Coast of the United States, into and across the southern states, and as far south as Panama. Even as U.S. laws and attitudes turned against Asian immigrants, these men worked the India craze to their advantage. Between the 1890 os and the 1920 s, as the policing of immigration shifted from the regime of the Alien Contract Labor Law to that of the explicitly exclusionary Immigration Act of 1917 (also known as the Asiatic Barred Zone Act), these men built upon existing ties of kinship and newly established connections within U.S. communities of color to build, maintain, and expand their operations. In their own day, they became a regular fixture at North American tourist sites and on the streets of major U.S. cities. Yet they have vanished from historical memory.

Buried in hundreds of fragmentary archival documents-ships' logs, census records, marriage certificates, local news items-the stories of these men illuminate a very different trajectory of migration to the United States from those celebrated in the national mythology. The peddlers did not leave their homeland behind in order to start new and better lives in the United States. Like other sojourning laborers of their day, they moved often, following the temporary openings and shifting demands of the U.S. and other economies. In their case, the "opening" was an expanding 
American culture of travel, tourism, and consumption and a broad demand for Oriental goods. Rather than reconstituting their Indian families in the United States, they forged different, sometimes temporary, forms of affiliation in the places they peddled goods, while continuing to function-through remittances and return visits-as part of economic circuits that stretched back to their families and home villages on the subcontinent. ${ }^{10}$ Rather than forming their own enclaves in U.S. citiesethnic neighborhoods where they sought to replicate in miniature the places they left behind-these peddlers built a global network that was multiethnic and rooted in segregated black neighborhoods. The men who moved through this network had to navigate the economic circuits, national borders, social spaces, racial ideologies, and consumer desires of both Great Britain and the United States. They were living, working, and moving in the shadows of two empires.

\section{Peddlers of Notions}

Today, when we think of U.S. fads and fashions for India, we tend to focus on the recent mass popularity of yoga and Bollywood films or on narratives of self-discovery in the East such as Elizabeth Gilbert's bestselling Eat, Pray, Love. The hippie counterculture of the late 1960s, with its obsessions for Indian music, fabrics, and spiritualities, also remains strong in the public memory. It is largely forgotten that at the turn of the twentieth century the United States was in the grips of a craze over India and "the Orient" that was, in some ways, larger and more pervasive than anything that has occurred since. Between the 188 os and 1920s, Americans from all classes and walks of life were drawn to an "India" that was, in essence, a collective fantasy. Elites of cities such as New York, Chicago, Boston, and Philadelphia explored Vedantist philosophy and attempted the contortions of "tantrik" yoga. A young Isadora Duncan performed her interpretations of Eastern dance, in bare feet and flowing robes, on the lawns of Newport, Rhode Island's finest mansions, while Ruth St. Denis performed in Indian-style on Broadway, bedecked with jewels and wrapped in a colorful silk sari. The New Thought writer and publisher William Walker Atkinson built a national audience for his mail-order books on clairvoyance, mind control, and 
the "Hindu-yogi science of breath," published under pseudonyms such as Swami Panchadasi, Yogi Ramacharaka, and Swami Bhakta Vishita. ${ }^{11}$

Meanwhile, the sexualized figure of the Indian "nautch" dancer became a staple of American burlesque theaters. Southern growers marketed tobacco under brand names such as Hindoo, Mecca, Mogul, and Bengal, with labels that depicted Ameers and maharajahs, palaces, hookahs, and dancing girls. Tin Pan Alley songwriters churned out show tunes such as "My Hindoo Man" and "Down in Bom-Bombay," which middle-class Americans sang to amuse themselves in the piano parlors of their homes. Circuses and exhibitions competed to present ever-larger menageries of Indian elephants and camels and ever-more spectacular recreations of Indian, Sinhalese, and other "native" villages. Such exotic public spectacles reached new heights in 1904, when the owners of Coney Island's Luna Park turned fifteen acres of the Brooklyn amusement park into a replica of the city of Delhi and "imported" three hundred Indian men, women, and children, forty camels and seventy elephants to live there for the summer season. Several times a day the "natives" and their animals marched through Luna Park, performing a re-creation of the Delhi Durbar - the grand procession that had occurred in India the year before to mark the ascendance of King Edward VII of England to the imperial throne. By 1909, even the Wild West showmen Buffalo Bill Cody and Gordon "Pawnee Bill" Lillie joined in the craze, touring a "Far East Show" across the U.S. Midwest and South that featured Arabian horsemen, a troupe of Sinhalese dancers, a "Hindu fakir," and a "nautch dance ballet." ${ }^{.12}$

For Americans of the era, "India" was presented as part of a mysterious and exotic "Orient" that took in the entire swath of North Africa, the Middle East, India, and Ceylon. This "Orient," in turn, was a blur of images, stories, references, and fantasies, derived from the contexts of the British, French, and other European empires. In their original context, Orientalist narratives and imagery had performed a particular kind of work. The British portrayal of India as the seat of a once great but now decaying civilization provided moral and political justification for the imposition and maintenance of colonial rule. ${ }^{13}$ In the American context, Orientalist notions were more free-floating. Unmoored from the daily exercise of colonial power, they entered the realm of the United States' 
growing cultures of self-improvement, mass entertainment, and mass consumption. Ideas about India took on new life and meaning in a society in which people's identities and social standing were increasingly defined by what they consumed and displayed. ${ }^{14}$

This was nowhere more apparent than in the turn-of-the-century fashion for "Oriental goods." As "Indian" and "Oriental" ideas, images, and amusements proliferated, Americans developed a seemingly insatiable desire for items that connected them to the East of their imaginings: silk scarves and shawls, cushion covers, wall hangings, rugs, brassware, carved and enameled boxes, jewelry, incense, perfume. This was a trend that had, over a very short span of time, traveled across both geographic and class lines. Earlier in the 1800s, the fashion for fine silks, rugs, and porcelain from India, China, Japan, and the Middle East had begun among the upper classes of London and Paris, for whom the display of luxury goods from the far reaches of empire was a sign of both power and sophistication. Elites in U.S. cities quickly followed the lead of their class counterparts in Europe, using "Oriental" and other foreign commodities to assert their own worldliness - at precisely the moment that the United States itself was growing as an imperial power. Men in New York, Chicago, and elsewhere outfitted their smoking rooms with plush Oriental rugs, hookahs, tiger skins, elephant tusks, daggers, scimitars, and images of "eroticized Eastern women"-goods that simultaneously conveyed the conquest of far-off lands and conjured the fantasy world of the Eastern harem. ${ }^{15}$

Upper-class women used Oriental goods to create lavish schemes for the interiors of their homes. Chicago's society matron Bertha Honoré Palmer, for example, decorated her Lake Shore Drive mansion in a series of regionally themed rooms. According to historian Kristin Hoganson, the home "had a Spanish music room, English dining room, Moorish ballroom, Flemish library, and French and Chinese drawing rooms. Upstairs, Bertha Palmer slept in a bedroom copied from a Cairo palace."16 Such women, Hoganson argues, used themed interiors to push beyond domestic constraints - to assert their connection to a wider world. At the same time, American women drew upon the cache of meanings that surrounded Oriental goods to challenge the propriety of the Victorian era; as the century came to a close, the American "New Woman" marked her 
independence and liberation by owning, wearing, and displaying goods that conjured Western ideas of a sensual and exotic East. ${ }^{17}$ By this time, a wave of popular writing about interior design promoted a scaled-down version of upper-class decorative styles to middle-class American women. Unable to furnish multiple themed rooms, women of lesser means were encouraged to combine several themes in a single room. They could "stuff the entire world into their parlors, confident that this was au courant." ${ }^{.18}$ Oriental goods thus became a marker of class status, and a vehicle of class striving, at multiple levels of society. While upper-class American women displayed high-end items from "the East" to assert their equivalence to European elites, the possession of items at the lower end of the scale-embroidered fabrics, cushions, throws, and other small goodsallowed middle- and lower-middle-class women, in turn, to emulate the American upper classes and lay claim to their own "sense of European sophistication."19

As Oriental goods entered the realm of mass consumption, the spaces in which they were bought and sold also expanded. Earlier, the sale of Oriental goods had largely been limited to high-end department stores and suppliers such as Liberty in London, Samuel Bing in Paris, and Tiffany in New York. ${ }^{20}$ By the 1880 s and 1890 os, a broader array of importers, retailers, and department stores were providing such goods to the middle-class market. ${ }^{21}$ In New York City, these included Erich Brothers, W. \& J. Sloane, Macy's, Lord and Taylor's, Cowperthwaits, and the specialty retailer A. A. Vantine, which boasted of being the "largest Japanese, Chinese, and India house in the world." Under the banner of its unique logo-the flags of Japan and China, crossed, beneath the crescent moon and star of Islam-Vantine's sold an astonishing variety of goods, from rugs and silks to teas, coffees, dinner gongs, teak furniture, "Kutch" sandalwood talc, and perfumes with names like "Java Lily" and "Delhi Heliotrope."22 Oriental goods also found a ready market within the growing spaces of middle- and working-class leisure: resorts, amusement parks, exhibitions, and beach boardwalks. Here, Oriental gift shops and pack and pushcart peddlers sold exotic souvenirs, curios, and handicrafts to Americans on weekend day trips and holiday travels. ${ }^{23}$

It was in this context that a handful of small-scale traders from West Bengal set out for the United States. The men were from a Muslim 
community in the district of Hooghly. Here, in a cluster of villages thirty miles northwest of the city of Calcutta, members of the local peasantry had engaged in the production of cotton and silk handicrafts for generations, supplementing what they produced and earned through farming with the sale of clothing and domestic goods embroidered in the intricate decorative style known as chikan. Accounts suggest that most of the needlework was done in the home during times of the year "when work on the farm is slack" and that it was predominantly women who produced the embroideries, while "their men" traveled out to "sell these products in home-markets. ${ }^{924}$

It is difficult to pinpoint the exact origins of the operation that brought Hooghly's handicrafts halfway around the world to the United States. In what is perhaps the only detailed narrative account of the network's activities in the United States, the expatriate Indian nationalist newspaper the Hindusthanee Student suggested in 1917 that the peddlers had first been forced beyond their regional orbit under the rule of the British East India Company. In the early nineteenth century, the British had flooded Indian markets with their own machine-made textiles and imposed high tariffs on Indian goods, undermining the indigenous textile industry and weakening internal demand for cotton and silk handicrafts like those of Hooghly's villages. ${ }^{25}$ The British also pushed aggressively to regulate and dominate the arenas in which goods were bought and sold on the subcontinent, the bazaars in which Hooghly's chikondars would have operated. ${ }^{26}$ During this period, to which the Hindusthanee Student simply referred as "the decline," men from Hooghly were forced to find new markets for chikan goods and began to travel overseas. These small traders, or chikondars, first made their way outward from Calcutta to South Africa and Australia, and by the 1880 s, after prospering in these locations, "the first batch, consisting of ten or twelve men, dared the perils of the unknown" and set out for the United States. Having been displaced by colonial pursuits on the subcontinent, these men used the very infrastructure of the British Empire to go beyond the empire's reach. They traveled thousands of miles through the circuits of colonial seaborne trade to a place where the scarves, handkerchiefs, tablecloths, and wall hangings embroidered in Hooghly villages had become the stuff of fashions, fancies, and fantasies. ${ }^{27}$ 
Hooghly's chikondars were not the first Indian traders to make such a shift, and the story of one group that preceded them sheds some light on the dynamics that may have led Hooghly's peddlers overseas. In the 186os, Sindhi Hindu merchants from the city of Hyderabad, west of Karachi, began making trips outward from the subcontinent to sell a range of regionally produced handicrafts. At the height of their operations, the Sindhi networks stretched eastward from Bombay through Singapore, Shanghai, and Manila to Kobe, Japan, and westward through Port Sudan, Port Said, Valetta, and Gibraltar-or via Cape Town and Freetown-to Panama. According to historian Claude Markovits, the Hyderabad network grew out of a confluence of events tied to the expansion of the British Empire. In the 1800 s, the British created an infrastructure for the extraction of goods and raw materials from northwest India: a deepwater port in Karachi; rail lines between rural Punjab and Karachi's port; steamships traveling outward, both to the east and to the west; and the canal at Suez, which drastically reduced the time and expense required to transport goods from India to Europe. In shifting the commercial center of Sindh from Hyderabad to Karachi, the British disrupted previous economic relations and means of livelihood in the Hyderabad region, among other things weakening the traditional markets for local handicrafts such as textiles, lacquerwork, and embroidery. A small number of Hyderabadi handicraft dealers began making sales trips to Bombay and discovered that there was a strong demand for their goods among Europeans in the expanding colonial port city. This information was brought back to Hyderabad, and regional merchants decided not just to sell their goods in Bombay, but also to move out to other sites with large numbers of traveling Europeans. They began, in the early 1860s, by making their way to Egypt, which had become a destination of choice for British and other European tourists. As colonial conquests, steam navigation, and the construction of major shipping canals opened the world up to European leisure travelers and the modern-day phenomenon of tourism began to take shape, these Sindhi merchants established outposts everywhere that Europeans sailed, selling "silk and curio items from the Far East and India" at sites throughout the world. ${ }^{28}$

Hooghly's peddlers of cotton and silk went through a similar process, establishing a base of operations in Calcutta and then moving outward. 
Like the Sindhi traders, they began by selling their goods along British imperial circuits-in South Africa and Australia-but then branched into a vast territory that the Sindhi peddlers had left untouched: the United States. Here they carved their own pathway for the sale of embroideries and curios, moving through a series of U.S., Caribbean, and Central American sites of travel and tourism. They began with New Jersey, whose beach boardwalk towns were some of the era's premier sites of popular recreation on the Eastern Seaboard. During the summer season, the hotels, beaches, and amusement parks of Long Branch, Atlantic City, and Asbury Park drew hundreds of thousands of working people from Philadelphia and New York City. It was a crowd that was newly able to partake of regular leisure activities, what New Jersey historian Charles E. Funnell has described as the "lower middle classes ... lesser white collar workers of all varieties including the many different kinds of clerks staffing the commerce and retail trade of Philadelphia ... [and, increasingly] women, employed [in the cities] in growing numbers as salesgirls." 29 The resorts made their money by encouraging and catering to this group's desire to regard itself as class ascendant; as Funnell puts it in his description of Atlantic City, "the values expressed in the resort's entertainment were those of citizens vigorously striving for the good life which ... they imagined the upper middle-class and rich to enjoy." "Oriental" items such as silks, embroidered cloth, and small trinkets and curios were accessible and affordable markers of this good life; the demand for them among New Jersey's holiday makers was significant enough that "Oriental gift shops" became a prominent feature of the resort towns' boardwalks, and Long Branch, Atlantic City, and Asbury Park became fertile ground for individual fancy goods peddlers from "the East."

The earliest fragments of evidence that place Hooghly's chikondars in the region of New Jersey date back to the mid-1880s. Ships' manifests show that small groups of Indian Muslim "traders," "hawkers," and "merchants" were entering the United States through the port of New York roughly once a year during fall and winter months. In September 1884, for example, two Indian "merchants," Sheik and Gorhan Ally, arrived in New York on the SS Edam from Boulogne-sur-Mer, France; in January 1885, the merchants Waheed Bux and "Moostakim" arrived on 
the SS California from Calcutta; and in February 1888, four Indian "hawkers," Sultah Ahmed, Saidh Bhoole, and Mohammad and Shaikh Hossain, arrived on the SS Waesland from Antwerp, Belgium. ${ }^{32}$ These appear to be the Hooghly peddlers' first forays into the United Statestrips that laid the foundations for their network. Two of the men on these early voyages, Waheed Bux and Mohammad Hossain, would continue to make journeys into, out of, and across the United States for the next twenty years. By the end of the 188 os, they and others from their region had established a distinct pattern of sojourning migration centered on the summer season of New Jersey's beachside resorts. ${ }^{33}$

It was around this time that U.S. commentators began to take notice. On May 29, 1889, Mohammad Hossain accompanied nine other men from India to New York, traveling the final leg from London on the SS Egyptian Monarch. Although the ships" manifest listed the men as "laborers," the Brooklyn Eagle reported the true nature of their business, noting the day after their arrival that the Egyptian Monarch had "brought about a dozen Hindoo peddlers who will do business at Long Branch in shawls and tablecloths. ${ }^{934}$ In the racial vernacular of the turn of the century, these Muslim men, along with Hindus, Sikhs, and all others from the subcontinent, would be marked with the term "Hindoo." Two years later, on July 19, 1891, Hooghly's chikondars again came to the notice of the press. This time, they warranted a full paragraph in the Chicago Tribune. Under the headline "Hindoos in America," a reporter wrote: "The dark-skinned Hindoo peddlers who infest the seaside resorts of the Jersey coast in summer are very interesting people. They are invariably courteous and their general shrewdness when trying to affect a sale is most engaging. As a rule, they are handsome men with clean-cut features and intellectual faces. They speak Hindustanee and occasionally Bengali, while their English is excellent. ${ }^{935}$ While steeped in condescension, this news item publicly marked the beginnings of what would be a decades-long presence of Bengali peddlers within the cultural and commercial arena of New Jersey's seaside resorts.

From 1889 onward, the peddlers' voyages became more regular and their population in the United States increased. In the 1890s, groups of chikondars arrived at Ellis Island like clockwork during the first half of each summer season, on their way to the New Jersey boardwalks to 
sell their wares. As the earlier traders gained their footing in the United States and remittances began to flow back to their villages, the number of Bengali peddlers arriving each year grew. ${ }^{36}$ Seven chikondars arrived from Calcutta in June 1894; the following June it was twenty, then eleven in June 1896 and twelve in June 1897. By this time, the Bengali peddlers' operations had taken the shape of a full-fledged and wellorganized network. At the end of each season, between two and seven men typically left the United States to return to Calcutta, and then another group of peddlers sailed from Calcutta to New York at the beginning of the following summer, presumably with a fresh stock of embroidered silks, cottons, and other small saleable items. Each of these groups included a core of five or six men who had traveled to the United States in previous years. They included Abdul Subham, Sofur Ally, Jainal Abdeen, Roston Ally, and Solomon Mondul in 1895 and Abdul Rahman, Mohammad Hossain, Eshrak Ali, Mubarak Ali Mondul, Abdul Wahab, and Abdul Latif-as well as Abdul Subham and Solomon Mondul again-in $1896 .{ }^{37}$ Only a few of these peddlers returned to the subcontinent at the end of each summer season; the others continued to expand the network's reach within the United States. From the late $1880 \mathrm{os}$ onward, New Orleans became the center of their operations during the fall, winter, and spring. According to one account, "In September, when the summer resorts ... closed, [they came] down to the South along with the climate-changers and pleasure-seekers and continued their business as in the north, to move back to the north the next summer."38

In the late nineteenth century, New Orleans was one of the United States' most important hubs of travel and transport and was becoming a tourist attraction in its own right. New Orleans was connected by rail to every major city in the South as well as to the cities of the north. Trains ran, either directly or through connecting lines, northeast to Atlanta, Charlotte, Baltimore, Philadelphia, and New York; northward to Birmingham, Chattanooga, St. Louis, Louisville, Cincinnati, and Chicago; and westward to Houston, Dallas, and beyond. ${ }^{39}$ The port of New Orleans was the second busiest in the country; it connected the United States to the Caribbean and Central and South America. ${ }^{40}$ New Orleans' political and business elites were also in the process of remaking the city, transforming it from a port town tied to slave trading and the dwindling economies of 
cotton and sugar into a progressive metropolis on par with the great cities of the North. Under their stewardship, the Crescent City was to become a showcase of the modern South-one that would attract a yearround flow of tourists and travelers from all over the world. ${ }^{41}$

In the 1880 s, New Orleans developers turned Canal Street, which ran from the river up through the center of the city, into a glittering commercial thoroughfare, with shops, department stores, and offices on either side and a streetcar running through the middle. ${ }^{42}$ The nearby French Market, in the meantime, was promoted as a kind of portal to a romanticized version of New Orleans' Creole past. A travel feature that circulated in U.S. newspapers in December 1903 described the French Market as "an eighteenth century market in a twentieth century city," hailing its "quaint customs," its "kaleidoscope of sights and . . . Babel of sounds." ${ }^{93}$ Boosters promoted and advertised the yearly celebrations of Mardi Gras with the aim of drawing ever-greater crowds from outside the city, while simultaneously, if less explicitly, they built an international reputation for the city's sex district, Storyville. In these years, New Orleans became a city associated with pleasure, fantasy, and consumption. By the turn of the century, tens of thousands of tourists were flocking to Mardi Gras each winter, and hundreds of thousands were visiting the city each year. ${ }^{44}$

New Orleans' growing tourist trade and its evolving identity as a site of pleasure and fancy made the city fertile ground for the men from Bengal, for these "peddlers of notions" from far-off India. Fantasies of and goods from "the East" already circulated widely in the city. Over the years that Mardi Gras grew as a national attraction, the city's elite AngloAmerican parading krewes-Comus, Proteus, Momus, and Rexfrequently presented lavish Indian- and Eastern-themed processions. When New Orleans held its International Cotton Exhibition in 18841885, the items displayed in the Asian pavilions were so popular that an Oriental Exhibition Store was opened on Canal Street in the heart of the city's commercial district. Across the avenue, Canal Street's fanciest department store, Maison Blanche, sold items at the high end of the Orientalist economy—plush carpets, fine silks, and porcelain-to local elites and wealthy travelers. A few blocks away, Storyville's madams thickly decorated the interiors of their brothels with Eastern rugs and wall 
hangings, drawing in customers through the era's fantasies of the harem and hiring "Oriental danseuses" to work alongside the Districts" more famous "mulattas," "quadroons," and "octaroons." 45

Turn-of-the-century New Orleans was also a city full of peddlers and neighborhood markets. For years, women of African descent had worked independently as peddlers and market-stall vendors selling various perishable and dry goods. ${ }^{46}$ This was also the case among members of new immigrant groups, who, between the 1870 s and 1890 s, became a presence all over the city. "The Poydras and Dryades street markets," writes historian Richard Campanella, "attracted Orthodox Jewish vendors from Russia and Poland; the French Market drew Sicilians; the Irish dominated the Suraparu and St. Mary's markets, and the Chinese created a series of shops on Tulane Avenue, which became known as Chinatown." 47 By the turn of the twentieth century, the tourists and locals who visited the French Market could find stalls and vendors representing every one of New Orleans' many communities, from the oldest to the most recently arrived. "Nowhere else within such a small compass can one discover so great a variety of nationalities, languages and quaint customs," wrote the author of the 1903 travel feature. "Within a few steps of where one stands are stalls presided over by Germans, Frenchmen, Chinamen, Hindoos, Jews, Englishmen, Irishmen, Malays, Spaniards, American Indians, Moors, Italians, Mexicans, Cubans, Creoles, as well as Africans of all shades and blends." 48 It was in this arena that the Bengali sellers of embroidered silks appear to have found their niche. They sold their "Oriental" wares amid the purveyors of every possible kind of produce and small good, in the French Market and on the city's streets.

In 1900, the federal census recorded twelve men from "Hindoostan" living in New Orleans. All were members of the peddler network-men who had begun making trips through Ellis Island in the 1880 s and $1890 \mathrm{os}$ to peddle goods on the New Jersey seaside. Ten of these men lived together in two shared apartments on the outskirts of the Storyville sex district. Alef Ally, Aynuddin Mondul, and Ibrahim Musa lived at 1428 St. Louis Street; Jainal Abdeen, Solomon Mondul, Abdul Subham, Sofur Ally, and Eshrack, Bahadoor, and Majan Ali all lived at 1420 St. Louis Street. The men were mostly in their midthirties to late forties and already had years of experience behind them selling Oriental goods to 
U.S. consumers. They had moved to St. Louis Street around 1895, two years before the creation of Storyville, when the block was part of an area consisting of boardinghouses, bars, clubs, brothels, and low-rent residences. Here, the peddlers were within walking distance of three areas of the city that would have been crucial to their work: the French Market, where some of them sold from stalls; the commercial district along Canal Street, which offered crowds of tourists and middle-class window-shoppers; and the railway terminal on Rampart Street, which connected the Bengalis to points north, east, and west. ${ }^{49}$

The chikondars had been living on St. Louis Street for about five years when they next garnered the attention of the press. On May 25, 1900, the Daily Herald of Biloxi, Mississippi, published a detailed dispatch from one of its correspondents in New Orleans, describing a group of "Hindoo peddlers" who were working on the streets there. Published under the heading "Not Very Dignified-Amusing Story of an Oriental Who Took a Bicycle Ride," the article opened with its author's musings about a growing population of new immigrants in New Orleans: "You know we have quite a colony of East Indians here who wear black skullcaps and long-tailed frock coats and prowl about town peddling rugs and such like. I must confess there [has] always been something strangely fascinating to me in the appearance of these fellows. They look so preternaturally solemn, and have such an air of oriental mysticism . . . that I can't help believing they are as wise as Solomon and are laughing in their sleeves at us poor barbarians while incidentally they are loading us up with their ridiculous rugs." The writer then relayed a longer anecdote about his encounter with one of the peddlers. While walking down an unspecified side street in the city, the author had looked up to see an Indian man heading toward him on a wobbling bicycle. He described the rider as "a lean bronzed gentleman with a scraggy, coal-black beard and piercing eyes" and noted with evident pleasure that the man was "humped over like a camel and making desperate efforts to keep his balance." While he granted that the peddler "preserved a certain indescribable dignity," the author immediately went on to undermine it. "There was something monstrously incongruous in the idea of a Hindoo on a bike," he wrote: "I would as soon think of seeing a bishop on a trapeze, and I stood transfixed with amazement, while he very nearly ran me down. But 
instead of saying, 'Make way, oh! Sahib, for thy servant to pass,' as he should have done, he called me an old fool in very good English, and asked me whether I wanted to be killed." Claiming that he was "too surprised to get mad," the Daily Herald's correspondent provided another self-satisfied description of the rider losing control of his bicycle, flying through the air "with his arms spread out like a frog," and slamming onto the pavement. To bring home his central point, the writer concluded with the claim that "according to the books [the peddler] should have accepted the misadventure with oriental stoicism. On the contrary, he scrambled up and proceeded to kick the stuffing out of both tires. ${ }^{.50}$

If we can look beyond its tone of racial superiority and its obvious satisfaction with an Indian immigrant's misfortune, the Daily Herald's article is revealing in many ways. First, the article acknowledged the presence of Indian Oriental goods peddlers as part of the social and economic landscape of New Orleans at the turn of the twentieth century. Second, it implied, in musing that the peddlers were "laughing in their sleeves . . . as they are loading us up with their ridiculous rugs," that they were selling such goods on the basis of what the author saw as a ruse of Eastern authenticity. Third, it demonstrated a clearly developed set of fantasies and expectations about who the men were and how they should be behaving_as "mystic" and "stoic" Orientals_ideas that the author clearly assumed his readership would recognize and share. Finally, the article inadvertently recorded these Indian peddlers' capacity both to use (as salesmen) and to defy such Orientalist ideas and expectations. What the Daily Herald's reporter likely did not know was that the men he was describing — and ridiculing — were in fact part of a complex global trade network that would soon stretch from the villages of West Bengal to the Canal Zone of Panama.

\section{From the Hooghly to the Mississippi to the Panama Canal}

By the first decade of the twentieth century, the Bengali peddlers' operation worked like a well-oiled machine. If its origins lay with small-scale peasant-traders, as early reports suggest, the chikondars' network eventually came to resemble the operations of much larger Indian merchant and banking groups. It involved a group of "merchants" or "dealers" 
based in Calcutta and another group of distributors in U.S. cities, while it continued to draw in less-experienced and -traveled young men from rural Hooghly to peddle goods overseas. A 1908 report by the U.S. Department of Commerce and Labor described an operation that was small but complex and highly coordinated. Over the course of each six to twelve months, a few merchants based in Calcutta purchased batches of chikan goods from producers in Hooghly's villages. When they had collected enough to fill "a medium-size dry goods box" on an outgoing steamer, they shipped these goods to the customhouses in New Orleans, Charleston, Savannah, and Philadelphia, where other members of the network, usually their kin, distributed the embroidery to individual chikondars, who then fanned out to sell the goods to American tourists and leisure travelers. ${ }^{51}$ New peddlers were drawn into the network through family and kinship ties and largely hailed from the cluster of villages where the chikan goods were being produced..$^{52}$ These included Babnan, Sinhet, Alipur, Chandanpur, Mandra, Bandipur, Bora, Dadpur, and Gopinathpur. ${ }^{53}$ Archival records indicate that, once a year, these new recruits made their way over land or down the Hooghly River to a predominantly Muslim neighborhood in the southern part of Calcutta known as Collinga Bazar. ${ }^{54}$ Here, a number of more senior traders with ties to the Hooghly District-likely the men described as "merchants" in the 1908 reportoccupied a series of addresses on Kerr Lane and Collin Lane, two small side streets off Collinga Bazar Street. Novice members of the network came from their villages to these addresses before setting off for New Jersey and New Orleans. It is probable that, like the first members of the network, who had voyaged to the United States in the 188 os, they brought additional goods in their luggage, to demonstrate to customs officials that they were independent traders and to supplement the items shipped in advance to the U.S. nodes of the network. ${ }^{55}$

Two descriptions of Collinga Bazar in the late nineteenth and early twentieth century-one quoted in P. Thankappan Nair's A History of Calcutta's Streets and the other written by Rudyard Kipling-both identify it as an area of inexpensive accommodations and drinking establishments that was home to a semi-permanent population of female European sex workers and the many sailors of different nationalities who passed through the port of Calcutta. Although British colonial officials did 
not officially "legalize" the activities of these women, Nair states that officials did actively attempt to contain what they called "white prostitution" within a closely circumscribed area in and around Collinga Bazar Street. ${ }^{56}$ Kipling's melodramatic account of this neighborhood, from his essay "City of Dreadful Night," gives a sense of the heterogeneous population that frequented the area, even as it reveals an attitude of racial and class superiority that Kipling shared with his white contemporaries in the U.S. South: "There are Seedee Boys, Bombay serangs and Madras fishermen ... Malays who insist upon marrying native women, grow jealous and run amok: Malay-Hindus, Hindu-Malay-whites, Burmese, Burma whites, Burma-native-whites, Italians with gold earrings and a thirst for gambling, Yankees of all the States, with Mulattoes and pure buck-n[- $]$ ers, red and rough Danes, Cingalese, Cornish boys . . . tunbellied Germans, Cockney mates ... unmistakable 'Tommies' who have tumbled into seafaring life by some mistake, cockatoo-tufted Welshmen spitting and swearing like cats, broken-down loafers, grey-headed, penniless, and pitiful, swaggering boys, and very quiet men with gashes and cuts on their faces. ${ }^{957}$ The similarities between Collinga Bazar in Calcutta and Storyville in New Orleans would have been numerous, but perhaps most significantly for the men who were moving from the former location to the latter was these neighborhoods' particular kind of cosmopolitanism-stemming from the intermixture of local workingclass residents with a mobile, international population of sailors, peddlers, sex workers, and participants in various underground economies. ${ }^{58}$ So, while members of the peddler network that stretched from Bengal to Louisiana had their origins in the villages of rural Hooghly, their entry into global circuits of trade and their travels to cities such as London, New York, and New Orleans were preceded, mediated, and no doubt conditioned by time already spent in this complex urban space within Calcutta.

Although occasionally, early on in their network's formation, Hooghly's peddlers managed to sail directly from Calcutta to New York, their voyages were rarely so straightforward. More often, the peddlers traveled by one British steamship westward from Calcutta to London and then after a few days caught another from either Southampton or Liverpool to the United States. On a number of occasions, the men traveled 
on one ship from Calcutta to Colombo, another from Colombo to London, and a third from Southampton or Liverpool to New York. The journey that eleven of Hooghly's peddlers took in 1896 was typical. These men spent close to a month on two steamships before arriving in New York and moving onward to the beach boardwalks of the New Jersey coast. They left Calcutta in early May on board the SS Goorkha, operated by the British India Steam Navigation Company (BISNC). ${ }^{59}$ Although it was a private company, the BISNC was deeply entwined with the operations of the British Empire. Its steamers transported mail, cargo, passengers, troops, military supplies, and indentured laborers between British colonial ports in South, Southeast, and East Asia and East Africa, as well as running long-distance services between Britain and Australian and Indian ports. Hooghly's peddlers may have known of or favored the line because it had a share in the traffic of Indian Muslim pilgrims to Mecca each year, or simply because it was one of the few lines that readily took "native passengers" between Calcutta and London. Although they were listed as "cabin" passengers on the Goorkha, one source states that British India Steam Navigation kept Indian passengers on deck for the duration of the journey. ${ }^{60}$

The Goorkh a first traveled down the eastern coast of India, picking up passengers in Madras and Colombo, then rounded the tip of India and sailed westward across the Arabian Sea. It stopped again to pick up passengers at Aden in Yemen, traveled northwest across the full length of the Red Sea, passed through the Suez Canal into the Mediterranean, and docked at Port Said, Egypt. In May, this journey would have been extremely hot, especially for those who had to remain on deck. From Port Said, the Goorkha sailed onward to London. It first took on more passengers in Naples, Italy, then crossed through the Strait of Gibraltar into the Atlantic Ocean, steamed northward to the mouth of the Thames River at Southend-on-Sea and made its way upriver, completing its journey in London's East End docklands. ${ }^{61}$ Soon after the eleven peddlers disembarked on May 28, they traveled overland eighty miles southwest to the port of Southampton, where they boarded an outbound steamship for New York, the SS St. Paul. They then spent the next eight days crossing the Atlantic Ocean in the steerage section of the St. Paul. Here, their accommodations would not have been much better than on the first leg of 
their trip. "Steerage" compartments in this era typically consisted of a series of large spaces below deck with low ceilings, dim light, and minimal air circulation that shipping companies filled with rows of three-tiered metal-frame bunks. In the case of the St. Paul, the eleven traders from Bengal shared steerage with 350 other travelers, 325 of whom were migrants, immigrants, or sojourners like themselves. ${ }^{62}$

From the 1890 s through the 1910s, the Bengali peddlers' annual journey to the United States followed a similar pattern. ${ }^{63}$ The activities of the peddlers on the U.S. side of the network, however, became more coordinated and complex. After passing through Ellis Island, each group of peddlers split up to cover the different New Jersey seaside towns. One or two members each would head to Atlantic City, Asbury Park, and Long Branch, suggesting that they may have been acting not only as peddlers, but also as couriers, transporting a fresh stock of goods for other members of the network to sell over the course of the summer. These other men were already in the United States, having come on previous years' journeys and moved on to New Orleans and elsewhere to sell goods in the nonsummer months. In order to join the newly arrived peddlers in each New Jersey resort town, they would have traveled north on the Southern Railway's Fast Mail or Southwestern Vestibuled Limited-lines that were segregated until they reached Washington D.C.- - or on one of the coastwise ships that were, in these years, bringing the first waves of black southerners to North Atlantic cities as part of the Great Migration. At the end of the summer season, a few members of the Hooghly network returned to Calcutta, while the majority headed to the southern states once again.

Each year, more of the peddlers appear to have remained in the United States and the network ventured farther afield across the South. The population of Bengali Muslim peddlers operating in the United States steadily grew. In New Orleans, the U.S. Census captured a fivefold increase in the Indian peddler population between 1900 and 1910. There were now more than fifty Indian Muslim peddlers living in eight households around the perimeter of Storyville (Table 1). Of these, five were residences in which several peddlers lived together in groups, and each of these five group households included both older, more experienced traders in their thirties, forties, and fifties and younger, more recently arrived peddlers in their teens and twenties. Four of the chikon- 
dars, including thirty-eight-year-old Haji Haq and sixty-year-old Abdul Aziz, lived on North Johnson Street. Eleven, including at least two who were part of the group deported from Ellis Island in 1897-Solomon Mondul and Fazleh Rahman-lived on North Roman Street. Five more peddlers lived on Conti Street, and six, including fifty-one-year-old Abdul Goffer and forty-six-year-old Abdul Majid, lived on North Claiborne Avenue. Both Goffer and Majid appear to have been part of a group that entered the United States through Castle Garden twenty-two years earlier, in 1888. Perhaps the most significant New Orleans address was 1428 St. Louis Street. Here, Alef Ally, an embroiderer and merchant who settled in New Orleans in the mid-188os, had turned the building into a boardinghouse for twenty other peddlers from the network. These included a number of younger men who had arrived in the United States in the years since 1903, as well as a handful of more experienced and senior men, including what appears to be two members of the group turned away from Ellis Island in 1897: Musa and Mintoz Mondul. The presence in New Orleans in 1910 of at least half the men deported from Ellis Island in 1897 is a testament to the persistence of these traders, to the continuing demand for the goods they were selling in the United States, and, as will become apparent in the next chapter, to the labor of local women who helped ground the network in the city. ${ }^{64}$

The reporter who penned the Biloxi Daily Herald's dispatch about a "Hindoo on a Bicycle" was clearly prone to embellishment, but his comment that "East Indian peddlers" were "prowling all about town" suggests that even as early as 1900 , the men were numerous enough and spread out enough to be a noticeable presence on the streets of New Orleans. Given that the main tourist and commercial areas of New Orleans comprised an area of only about one and a half square miles, this is hardly a surprise, and by 1910, as their numbers grew, and as they likely split up the city into territories, their presence would have been even more striking. At the same time, there is evidence that from early on, groups of Hooghly's peddlers were making extended forays from New Orleans into other southern cities. As early as 1897, a Texas newspaper made note of two men, "Mohammed and Hamid Hassain," identified as "vendors of Oriental goods," returning to New Orleans after a period of time peddling in Fort Worth. In 1912, the Atlanta Constitution described 
Table 1. Indian Peddler Households in New Orleans, 1910

\begin{tabular}{|c|c|c|c|c|c|}
\hline Address & Name & Age & Arrived & Status & Occupation \\
\hline \multirow[t]{24}{*}{1428 St. Louis St. } & Alef Ally & 50 & 1885 & $\mathrm{Na}$ & $\begin{array}{l}\text { Merchant-- } \\
\text { Merchandise }\end{array}$ \\
\hline & Mahoma Moassa & 40 & 1903 & $\mathrm{Al}$ & $\begin{array}{l}\text { Merchant- } \\
\text { Merchandise }\end{array}$ \\
\hline & Abdul Jabbar & 39 & 1896 & $\mathrm{~Pa}$ & Merchant-Retail \\
\hline & Tarafat Ally & 38 & 1903 & $\mathrm{Al}$ & Merchant-Retail \\
\hline & Tazer Ally & 32 & 1907 & $\mathrm{Al}$ & Merchant-Retail \\
\hline & Manzur Ally & 24 & 1907 & $\mathrm{Al}$ & Merchant-Retail \\
\hline & Devan Husan & 32 & 1909 & $\mathrm{Al}$ & Merchant-Retail \\
\hline & Rohamat Ally & 28 & 1909 & $\mathrm{Al}$ & Merchant-Retail \\
\hline & Mazed Ally & 28 & 1907 & $\mathrm{Al}$ & Merchant-Retail \\
\hline & Bakshee Rohaman & 22 & 1907 & $\mathrm{Al}$ & Merchant-Retail \\
\hline & Mintez Mandal & 60 & 1904 & $\mathrm{Al}$ & Merchant-Retail \\
\hline & Joynal Abdin & 45 & 1905 & $\mathrm{Al}$ & Merchant-Retail \\
\hline & Abdul Jalil & 23 & 1907 & $\mathrm{Al}$ & Merchant-Retail \\
\hline & Imraz Zaman & 23 & 1909 & $\mathrm{Al}$ & Merchant-Retail \\
\hline & Abdul Rohim & 26 & 1908 & $\mathrm{Al}$ & Merchant-Retail \\
\hline & Abdul Sircar & 28 & 1907 & $\mathrm{Al}$ & Merchant-Retail \\
\hline & Nawazes Ally & 38 & 1906 & $\mathrm{Al}$ & Merchant-Retail \\
\hline & Sher Ally & 24 & 1906 & $\mathrm{Al}$ & Merchant-Retail \\
\hline & Sari Raddin & 24 & 1908 & $\mathrm{Al}$ & Merchant-Retail \\
\hline & Tawakul Hussain & 29 & 1909 & $\mathrm{Al}$ & Merchant-Retail \\
\hline & Fazla Sayed & 25 & 1909 & $\mathrm{Al}$ & Merchant-Retail \\
\hline & Jagatbandhu Dev & 25 & 1908 & $\mathrm{Al}$ & Student \\
\hline & Viola Ally & 12 & & & none \\
\hline & Celestine Gardner & 65 & & & none \\
\hline \multirow[t]{6}{*}{415 N. Claiborne St. } & Bundy Ally & 48 & 1904 & $\mathrm{Al}$ & Peddler-Dry Goods \\
\hline & Abdul Mozid & 46 & 1904 & $\mathrm{Al}$ & Peddler-Dry Goods \\
\hline & Abdul Goffer & 51 & 1905 & $\mathrm{Al}$ & Peddler-Dry Goods \\
\hline & Ilias Mondol & 25 & 1905 & $\mathrm{Al}$ & Peddler-Dry Goods \\
\hline & Monibur Rohman & 29 & 1906 & $\mathrm{Al}$ & Peddler-Dry Goods \\
\hline & Nozoff Ally & 27 & 1907 & $\mathrm{Al}$ & Peddler-Dry Goods \\
\hline \multirow[t]{5}{*}{1711 Conti St. } & Motiaz R. Mondol & 22 & 1909 & $\mathrm{Al}$ & Peddler-Fancy Goods \\
\hline & Boolie Mohla & 35 & 1909 & $\mathrm{Al}$ & Peddler-Fancy Goods \\
\hline & Sooleman Mohla & 28 & 1909 & $\mathrm{Al}$ & Peddler-Fancy Goods \\
\hline & Itias Rohman & 23 & 1909 & $\mathrm{Al}$ & Peddler-Fancy Goods \\
\hline & Sokas Sukiluddin & 36 & 1909 & $\mathrm{Al}$ & Peddler-Fancy Goods \\
\hline \multirow[t]{7}{*}{320 N. Roman St. } & Abdul Mondol & 33 & 1904 & $\mathrm{Al}$ & Peddler-Fancy Goods \\
\hline & Fazla Rohman & 31 & 1904 & $\mathrm{Al}$ & Peddler-Fancy Goods \\
\hline & Solmon Mondol & 40 & 1904 & $\mathrm{Al}$ & Peddler-Fancy Goods \\
\hline & Roudal Huck & 39 & 1907 & $\mathrm{Al}$ & Peddler-Fancy Goods \\
\hline & Abdul Osama & 45 & 1909 & $\mathrm{Al}$ & Peddler-Fancy Goods \\
\hline & Golam Rub & 26 & 1909 & $\mathrm{Al}$ & Peddler-Fancy Goods \\
\hline & Abdul Malick & 24 & 1909 & $\mathrm{Al}$ & Peddler-Fancy Goods \\
\hline
\end{tabular}


Table 1. (continued)

\begin{tabular}{llcccl}
\hline Address & Name & Age & Arrived & Status & Occupation \\
\hline & Wajed Ally & 30 & 1908 & $\mathrm{Al}$ & Peddler-Fancy Goods \\
& Abdul Rub & 19 & 1909 & $\mathrm{Al}$ & Peddler-Fancy Goods \\
& Abdul Rouf & 24 & 1908 & $\mathrm{Al}$ & Peddler-Fancy Goods \\
& Tazli Moddin & 55 & 1908 & $\mathrm{Al}$ & Peddler-Fancy Goods \\
323 N. Johnson St. & Hadgi Hojik & 38 & & & Peddler-Dry Goods \\
& Atowbbor Sny & 30 & & & Peddler-Dry Goods \\
& Abdul Kholock & 25 & & & Peddler-Dry Goods \\
& Abdul Aziz & 60 & & & Peddler-Dry Goods \\
\hline
\end{tabular}

Names are spelled as they appear in the original census documents. Reported arrival dates often appear to reflect most-recent rather than first arrival. Immigration status: Al=Alien; $\mathrm{Pa}=$ First Papers (ie: the individual has filed an Intention to Naturalize); $\mathrm{Na}=$ Naturalized.

Source: USDC/BC, Population Schedules for New Orleans, LA (various).

a group of thirty Indian peddlers who had traveled to Atlanta and had been selling goods there, "in and around the city," for two weeks. ${ }^{65}$

Such trips depended on a smaller number of Bengali men who settled, or stayed for extended periods, in cities throughout the South. Most of these men were members of the network who had worked the New Jersey seaside resorts or lived in New Orleans for some time and had then branched out to other southern cities, where they usually lived in and often married into local black communities. ${ }^{66}$ Once they were settled in these places, their function in the network was likely twofold: they both sold goods themselves, expanding the reach of the network's market, and provided an infrastructure for larger groups of peddlers to pass through from town to town, selling the network's silks and other goods. In port cities like Charleston, Savannah, and New Orleans, these men could also now act as middlemen, receiving goods shipped by kin in Calcutta through the local customhouses that could then be distributed to other peddlers. In the opening decades of the twentieth century, members of the network established outposts in several southern cities. ${ }^{67}$ Draft registration records give us a snapshot of the network's reach by the time the United States entered the First World War. In 1917-1918, thirty-five Indian peddlers filed their mandatory registration cards in New Orleans, seven registered in Charleston, South Carolina; six in Jacksonville, Florida; four in Memphis, Tennessee; and between one 
and three in Chattanooga, Tennessee; Galveston, Texas; Dallas, Texas; Birmingham, Alabama; and Atlanta, Georgia (Table 2). ${ }^{68}$

As the Hooghly network gained its footing in New Orleans and expanded through the southern United States, some of its senior members also moved farther south, bringing their wares to a series of ports in the Caribbean and Central America. Here, the colonial engagements of Britain and the United States had opened up multiple sites to Western tourism and leisure travel: Jamaica, Cuba, Puerto Rico, Panama, Trinidad.

Table 2. Draft Registrations of Indian Peddlers in Southern Cities, 1917-1918

New Orleans, LA Abdul Jobber Mondul, Abdul Ganie, Abdul Ganie Mondul, Abdul Jalil Mallick, Abdul Kholick Mollah, Abdul M. Mollah, Abdul Rohim Sarker, Abdul Surker, Abdul Ganie Mondul, Abdul Hamed Mondul, Abdul Wahed, Aminoola Rohimoody, Babur Alli, Dawood Rohman, Elias Mondul, Fozlay Rohman, Hafez Mosihor Rohman, Hassan Abdul, Jonean Sarker, Kiramuth Ali Mondul, Kolimudden Mondul, Monebor Rohman Mollah, Mocklajar Rohman, Mohammed A. Isscas, Monsur Ally Mondul, Mortoza Hassain, S. Atear Rohaman, S. F. Mowla, Shaik Rohim Boksh, Syed Abdul Fara, Syed Monsur Ally, Toffozul Hossain, Towakal Hossain Halder, Volu Mollah

Charleston, SC Sadeck Ali Mollah, Abdul Gaffer Mondul, Jogadish Chandra Goswami, Keramoth Ally, Mosud Ally, Rajab Ali, Syed Abdul Ganny

Memphis, TN Abdul Khalick, Abdul Robe Mondul, Azad Bauksh, Rashidul Hock

Chattanooga, TN Abdul Wade Mondul

Galveston, TX Abdul Ganie Mondul, Abdur Rohim Mondul

Dallas, TX Abdul Karim Mondol, Golam Robbaney

Birmingham, AL Ayub Mondul, Noserul Hawk Mondul

Atlanta, GA

Abdul Rubby, Mohammed Yeakub, N. H. Mondul

Jacksonville, FL Abdul Gany Mondul, Abdul Rohim Meer, Abraham Mondal, Roohul Amin Sircur, Sheik Abdul Rohman Mondul, Syed Awlad Ali

Names are spelled as they appear in the original draft registration documents. Jogadish Goswami (Charleston) appears to have originally come to the United States, via San Francisco, as a student in 1907, and later joined the network. USDCL/BIN: Declaration of Intention, J. C. Goswami, U.S. District Court of Charleston, SC, January 29, 1910.

Source: USSS/DRC, WWI Draft Registration Cards, Local Registration Boards of New Orleans, LA; Charleston, SC; Memphis, TN; Chattanooga, TN; Galveston, TX; Dallas, TX; Birmingham, AL; Atlanta, GA; and Jacksonville, FL. 
American periodicals of the day described such places to an increasingly mobile middle-class readership, while shipping lines promoted them as destinations for winter escapes, emphasizing their "delightful" climate and their easy accessibility via "luxuriously equipped ocean liners" sailing regularly from U.S. ports. Over the winter of 1907-1908, the New York-based Travel Magazine presented the Caribbean as if it were merely an extension of the United States; its monthly feature articles on seasonal destinations spoke in virtually the same breath of New Orleans, Savannah, Puerto Rico, and Trinidad, of Florida, Barbados, and Havana, while shipping companies advertised "Tours to the Tropics" that included Jamaica, Colombia, Costa Rica, and Panama. The Royal Mail Steam Packet Company's ad juxtaposed the January weather forecasts for New York ("Min. 10/Max. 15") and Kingston ("Min. 68/Max. 68") and offered "all inclusive" tours of Jamaica and the Isthmus of Panama. Hooghly's chikondars were one of several groups of peddlers who followed the winter "climate-changers and pleasure-seekers" from the United States and Europe into this circuit of warm-weather sites. ${ }^{69}$

The port to which they sailed most frequently was Colón, on the Caribbean coast of Panama. Between 1905 and 1909, several of the men who had begun peddling Hooghly's embroidery to vacationers along New Jersey's boardwalks in the 1890s-Panch Courie Mondul, Abdul Barrick, Abdul Aziz, and Solomon Mondul-all made trips to Colón, listing their occupations variously as "merchants," "traders," and "silksellers." Colón was a key city for the era's travelers-it was at one end of the fifty-mile Trans-Isthmian Railway, which had been used for decades to cross between the Caribbean and the Pacific Ocean. The route was now newly in the hands of the United States after more than a century of attempts-by the Spanish, the French, and even the Scottish - to control the crucial passage of people and goods between the Atlantic and Pacific worlds. In 1903, Panama had been a province of Colombia. The United States put its military might behind a group of local elites who sought to secede and in exchange gained sovereign control over the strip of land along which the railway ran, including its termini, Colón and Panama City. In 1904 the U.S. government's Isthmian Canal Commission and Army Corps of Engineers began construction of the canal along that route. It was to be, for the time, the jewel in the United States' imperial crown. ${ }^{70}$ 
By the time Panch Courie Mondul and three other members of the Hooghly network arrived on an initial visit in 1905, the number of tourists, travelers, and workers making their way to and through Colón was growing exponentially. Thousands of laborers made their way to Panama from the Caribbean, Europe, Asia, and the United States to work on the construction of the monumental canal and to make improvements to the railway, which was now transporting not only travelers and goods but workers, equipment, and the tons of earth and stone dynamited and dug up from the canal's route. The Bengalis were not the only Indians in the Canal Zone. Punjabi Sikh men were among the laborers working on the railroad, sent by labor recruiters on the subcontinent. ${ }^{71}$ Sindhi traders also set up their first shop in Colón in 1905 to sell Oriental goods to the other group of outsiders that began to visit Colón in increasing numbers: the "ships passengers who disembarked there and had time to engage in purchases while their ship was in harbour." Although by the late 1920s, Markovits writes, the Sindhis had gained a "complete monopoly" on this lucrative trade, Hooghly's peddlers appear to have had part of it in these early years. ${ }^{72}$

From 1905 through the 1910 s, the Bengali chikondars' trips to Colón formed a secondary circuit of their network's yearly migrations. Groups of peddlers traveled from Calcutta to London and then split up; some sailed on to New York, while others took the Royal Mail's ships from Southampton, England to Panama and eventually sailed back to New Orleans, New Jersey, or Southampton. Initially, smaller groups of chikondars made their way through this circuit: after Panch Courie Mondul's initial foray in 1905, three peddlers made the trip to Colón in 1906, and six did so in 1907. By 1908, other points in the Caribbean had been incorporated into the larger framework of the Hooghly traders' movements. That year, ten members of the network set out together from Calcutta to London and then split up to proceed to different territories: three continued onward to 1428 St. Louis Street in New Orleans, two sailed to Trinidad, and five sailed to Colón, Panama. Over the coming years, they would circulate in small numbers between New Orleans and New Jersey in the United States; Panama, Honduras, and Belize in Central America; and Trinidad, Jamaica, and Cuba in the Caribbean. ${ }^{73}$

The presence of Indian peddlers in these regions did not go unremarked upon. A 1909 article titled "School Teaching in Panama," 
published in the U.S.-based weekly The Independent, placed both workers and traders from India within the larger context of international travel and migration to "The Zone" during the construction of the canal. "On the street, our children meet men from all parts of the world," the author, a missionary schoolteacher, wrote: "The East Indian wearing his bright yellow or blue turban drives a dirt cart for the railroad or serves in the office of a watchman. Every other store is a Chinese shop filled with the ivories, carved woods, and silks from the Orient ... Assyrian peddlers and Hindoo merchants in their queer costumes go from house to house selling their wares. And on every hand, the child meets Spaniards, Frenchmen, and Italians." ${ }^{974}$ In August 1901, the Atlanta Constitution had provided a similar description of Indian traders in Havana, Cuba, where the number of American tourists and military personnel had quickly grown since the United States occupied the island in the wake of the Spanish-American War. In a travel article focusing on the Cuban city's "quaint" and "colorful" populations of peddlers, a Constitution correspondent described the "colony of Hindoos" that had taken root in Havana-made up, it would seem, of both Muslims and Sikhs, in that they were described as wearing "turbans or embroidered fezes." She claimed these men were "the most attractive and prosperous class of street vendors here," and walked from place to place carrying "a pack on the back weighing many hundred pounds, consisting of gorgeous East Indian and Oriental stuffs." The men were said to have "a large store down on Paula Street, and a dozen or more [men who] travel about the city and suburban towns within a radius of thirty miles, disposing of their things." As for the goods themselves, the author wrote, admiringly: "They have curious eastern embroideries in silk and cottons.... They make a specialty of draperies, and find ready sale for these, particularly among the Americans and in Columbia [military] barracks ... where the bare rough walls cry aloud for some artistic covering." 75

\section{In the Shadows of Empires}

The travels of Bengali Muslim peddlers within and beyond the borders of the United States are all the more remarkable for the fact that they occurred at a time of increasing anti-immigrant and anti-Asian sentiment in the United States. The period between the 1880 s and the 1910s-the 
years in which Hooghly's traders established and expanded their operations in the United States-saw a rapid rise in immigration to the United States. Immigrants from all over the world were coming through New York, San Francisco, and other U.S. ports in numbers the country had never before experienced. It was also a period of rising xenophobia, directed largely at the poorest and least skilled of the workers who were coming to U.S. shores-from Chinese railroad workers to Sicilian peasants. Over these years, the U.S. government developed an ever-more selective regime of immigration laws that explicitly used criteria of class and race to turn immigrants away from the United States. This process began with the Chinese Exclusion Act of 1882 and the Alien Contract Labor Law of 1885 and continued with the 1917 Immigration Act, which, among other things, instituted the Asiatic Barred Zone, the provision that brought virtually all legal migration from Asia to a halt. ${ }^{76}$

From the 1890 s to the 1910 , the most significant obstacle that Hooghly's peddlers faced at U.S. borders was the Alien Contract Labor Law. The Contract Labor Law was ostensibly enacted to stop U.S. employers from "importing" foreign laborers who might undermine the wages and conditions of U.S. workers. The law was also, however, an extension of the Chinese Exclusion Act and was suffused with antiAsian sentiments and assumptions. The 1885 law relied on a distinction between "free" and "unfree" migrants; it sought to limit labor immigration to people who were entering the country on their own initiative as "free migrants" - that is, to block the entry of indentured or contract laborers, who had been recruited, assisted, and bonded by their employers. ${ }^{77}$ The enforcement of this law was difficult and uneven, but the Bengali peddlers would have been more likely than many others to be accused of being bonded laborers. According to historian Adam McKeown, immigration inspectors were guided by Western notions of Asian societies as backward and despotic; Asian migrants were marked by the image of the "coolie," seen as inherently subservient and "unfree." At the same time, the Contract Labor Law made no distinction between large-scale employers, agents, and recruiters, and smaller kinship and family-based networks. ${ }^{78}$ The Bengalis' operation was a variant of the latter, but the more organized and coordinated it became, the more easily immigration officials could claim that arriving peddlers were "assisted" migrants, 
"bonded laborers," entering the United States in violation of the law, and were therefore to be detained and turned back.

The Bengali peddlers who were deported in 1897 came up against the Immigration Bureau's broad enforcement of the Contract Labor Law, and they were not the first. In 1890, a group of thirty-two Arab peddlers were detained when it was claimed that they worked for a "dealer in rugs and Oriental goods" with offices in Paris and New York. Hooghly's peddlers could be treated in the same way. The structure of their operation-in which new peddlers were brought into the United States by more established traders whose business extended from Calcutta through New Jersey, New Orleans, and Charleston—was such that U.S. authorities could construe the new members as men bonded to a larger concern, whose peddling was therefore a form of "unfree labor" and whose entry should be prohibited. This appears to have been the argument put forward by the Immigration Bureau's Board of Special Inquiry in 1897; although Moksad Ali, Obidullah, Fazleh Rahman, and the others were coming to the United States to sell handicrafts that had been made in their home villages - perhaps even by their relations-for generations, the twelve detainees were accused of being part of a scheme in which they were contract workers "peddling goods not their own." Each time they stood before Ellis Island's immigration inspectors, the Bengali peddlers faced the possibility of being accused again, pulled aside, put in detention, and deported. This risk would have only increased as antiAsian politicians and citizens' groups became more active and vocal in the years leading up to the creation of the Asiatic Barred Zone. ${ }^{79}$

How, then, did the Bengali chikondars establish such a wide-ranging presence in the United States and continue to move in and out of the country, year after year, for more than three decades? The peddlers succeeded in large part because they operated as a network; they shaped, structured, and coordinated their activities to ensure that people, information, money, and goods continued to flow across borders, even as conditions on the ground changed.$^{80}$ Their response to the 1897 deportations is a prime example of this agility. The peddlers who were already in the United States at this time appear to have used the years immediately following the deportations to shore up their presence and activities in cities such as New Orleans and Charleston. A number of these men 
began naturalization procedures-an option that was yet still open to them. ${ }^{81}$ But something else happened. The peddlers found other, more surreptitious routes in and out of the country. Ships' manifests for the period between 1897 and 1902 show almost none of the Bengali peddlers entering the United States officially through New York, Philadelphia, Baltimore, or New Orleans. Yet a number of these men did make their way out of and back into the United States over the course of these years. Solomon Mondul, for example, left New York for Liverpool with four other members of the network in September 1898 and had returned to New Orleans by 1900. Moksad Ali, one of the men detained and deported in 1897, also successfully made his way back to New Orleans by 1900, then left the country once again around 1901, presumably on his way to India, and then crossed back into the United States via Quebec, Canada, with one other member of the network in September 1902. ${ }^{82}$ When Hooghly's peddlers began to travel openly through Ellis Island again in 1903, they had changed tactics. They now entered the country in small groups in an effort, no doubt, to avoid arousing the suspicion of immigration authorities that they were under the employ of large-scale Oriental goods dealers.

They also began, around this time, to make use of the Contract Labor Law's loopholes and exceptions. The law contained a provision that allowed existing residents of the United States to assist family members and personal friends to come to the United States "for the purpose of settlement. ${ }^{983}$ So in 1903, when Hooghly's peddlers resumed their yearly journeys through Ellis Island, each now claimed to be entering the United States to join a relative or friend. Of the four men who arrived on the SS Teutonic on June 2, 1904, for example, Abdul Rajack stated that he was joining his "uncle, S. Serajuddin," Abdul Lotiff was joining his "father, S. Serajuddin," and Abdul Mojidda was joining his "friend, S. Serajuddin," in Atlantic City, while Joynal Abdin was meeting his "cousin, Majan Ali," in Asbury Park, before moving on to 1428 St. Louis Street in New Orleans. ${ }^{84}$ On board the SS Oceanic in July 1912, Kalimodden Sirkar was traveling from his brother, Hajee Abdul Bux, at 10 Kerr Lane, Calcutta, to his son, Abdul Rohim Surker, in Asbury Park; Abdul Khalik was traveling from his father, Nastik Ally, at 13 Kerr Lane, to his uncle, Rahim Bux, in Atlantic City; and Ebadur Rahman was traveling from his father, M. Mohram, at 13 Kerr Lane, to his brother, 
Fazla Mohla, in Asbury Park. ${ }^{85}$ It is quite possible that these claims of family connection were true, as there are indications that the network grew organically along lines of kinship as members recruited other family members and co-villagers to come to the United States. ${ }^{86}$ Indian familial relations were also broader in their interpretation than those in the United States, so that the traders may have referred to male cousins as "brothers" and their fathers" friends or elder co-villagers as "uncles." But familial claims were also a canny means of navigating the Contract Labor Law. Whether they were marking or exaggerating their connections to one another, ships documents clearly show that these peddlers constituted a group that was broadly related by village and region, if not by direct and extended family ties, and, at the borders, they used these ties to stake a claim for entry into the United States.

The chikondars' network survived, in other words, because it was dynamic. Between 1897 and 1902, peddlers bypassed Ellis Island and made their way into the United States through either Canada or smaller U.S. ports; after 1903, they entered Ellis Island in groups of four or five rather than ten, twelve, or twenty; and they came equipped with the names and addresses of relatives or friends who were residents in Atlantic City, Asbury Park, New Orleans, or Charleston. All these changes in the wake of the 1897 deportation suggest that members of the network brought information back to the subcontinent about the changing conditions in the United States and at its borders, and that the network adapted its strategies to these conditions. Information and coordination also played key roles at the local level. When younger and newer members of the network traveled with older traders or joined them in group households in New Jersey, New Orleans, and elsewhere, they would have been directed by the more experienced men, provided with information about each individual city or town, perhaps assigned neighborhoods or territories, and taught about how to approach customers to make sales. In this sense, the men who lived for extended periods in the network's regional hubs and outlying cities would have built a store of information crucial to the work of those members who were newer and more transient.

The wide-ranging circulations of some of the Bengali chikondars-and of the goods they were selling and the earnings they were generating-are 
a testament to just how strong and effective their network became over time. Evidence of the movements of individual peddlers is scattered across a range of archives from the 1910 s and 1920s-passport applications, draft registration cards, census records, and the manifests of ships coming through Ellis Island and the port of New Orleans. Pieced together, they trace out a remarkable set of movements, as the cases of $\mathrm{Fa}$ zleh Rahman, Abdul Gannie, and Noorul Huck demonstrate. In October 1913, Fazleh Rahman applied for a U.S. passport at the offices of the American Legation in Panama City, on the Pacific Ocean side of the soon-to-becompleted canal. This appears to have been the same "Fauslay Roman" who was living at 15 Wesley Place in Asbury Park, New Jersey, at the time of the 1900 U.S. Census. In applying at the American Legation, Rahman listed his place of birth as Calcutta and his occupation as "merchant." He stated that he had come to the United States from Southampton, England, in 1898, lived in Asbury Park for twelve years, until 1910, and then moved to Atlantic City. He had naturalized at May's Landing, New Jersey, on April 14, 1905. In 1912, Rahman had left New Jersey, returned to Calcutta, and after a brief stay there, traveled onward to Panama, where he had now been living for several years. In his passport application, Rahman claimed that he soon intended to return to Atlantic City but, prior to doing this, required the passport "for the purpose of engaging in business in Costa Rica." 97

Five years later, in 1918, Abdul Gannie, another Indian "merchant" who had naturalized with Fazleh Rahman at May's Landing in 1905, applied for a passport to travel to India via Japan and China "on business and for health." Originally from the village of "Batta, near Calcutta," Gannie had come to the United States via Southampton in 1896, and since then, his movements had been almost as far-reaching as Rahman's. In addition to having lived in "New Orleans, Long Branch, [and] Atlantic City," Gannie had been back to India twice, spending a total of eighteen months there in 1907 and 1909. His 1918 passport application was his third attempt to get U.S. traveling papers, and to support his application, he pointed to the case of a cousin, Noorul Huck, who had recently been granted a U.S. passport to travel to Calcutta for similar reasons. According to ships' manifests, census records, and his own passport application, Huck was another trader who had been headed for Fazleh 
Rahman's address in Asbury Park when he originally came to the United States on a ship from Liverpool in 1909. He had subsequently lived in Atlantic City for a year, stayed briefly in New Orleans, and then traveled to Galveston, Texas, before ultimately settling in Houston. ${ }^{88}$

One of the earliest indications of the volume of the trade these men were doing comes in the form of a short news item that ran in the Philadelphia Inquirer at the end of July 1902. The Inquirer reported the theft of a bag of items from the Atlantic City residence of an "East Indian peddler named Fahi Uddin"-an apparent mis-transliteration of Mohi Uddin Mondal. Mohi Uddin was a member of the Hooghly network who, at the time of the U.S. Census two years earlier, was living with six other Bengali peddlers in a cluster of households halfway between Atlantic City's train station and its boardwalk. The burglar had "put a ladder against [Uddin's] house and climbed in a second story window," making off with "a rich haul of fine fabrics valued at $\$ 500$ and . . \$ \$113 in cash." This was a rich haul, indeed, and would have represented a significant loss to the peddlers; it was equivalent to approximately $\$ 13,000$ in today's dollars. It likely represented the earnings that Uddin and his associates had generated during the first part of the summer season, and the remaining complement of goods that they were drawing on for their peddling each day. ${ }^{89}$

The stories of Mohammed Issa and Shaikh G. R. Mondul suggest the structure and size of the trade that the network was doing fifteen years later. In July 1917, Issa, a peddler born in "District Hooghly," traveled from Belize to New Orleans. On ships' documents, he listed Belize as his "last permanent residence" but stated that he had lived in New Orleans in 1916 and was now intending a three-week stay in the city, at one of the key addresses associated with the Hooghly network, 1825 St. Ann Street. Issa listed the "friend or relative" he was joining in New Orleans as "S. Karamat Ali" - who would show up three years later on the 1920 U.S. Census as a "Bengalese"-speaking peddler of silks. Issa was, in other words, connecting with other members of the network, and the fact that he intended only a three-week stay in the United States before returning to Belize suggests a trip made for the purpose of delivering earnings, renewing supplies of goods, or both. ${ }^{90}$ More telling is a trip made in November 1919 by Shaikh G. R. Mondul, a thirty-year-old merchant who, on ships' documents, listed his last residence as Tela, Honduras, and his 
languages as "Bengalese" and Spanish. On this trip, Mondul had made his way by land from Tela to the port of La Ceiba, Honduras, where he caught a steamship and sailed northward through the Caribbean and the Gulf of Mexico to New Orleans, carrying an astounding \$3,250-an amount roughly equivalent to $\$ 40,000$ in today's dollars. From New Orleans, Mondul was to sail back down through the Gulf and Caribbean to Panama, and ultimately from Panama to "Bengal, India." This strongly suggests that Mondul's purpose was either to deliver cash to his compatriots in New Orleans or to collect their earnings to add to his own, to courier back to Calcutta. ${ }^{91}$

Why has this group of South Asian migrants remained hidden to U.S. history? By the 1910s, Hooghly's peddlers were traveling extensively through the United States, the Caribbean, and Central America. Their presence was significant enough in places like New Jersey, New Orleans, and Atlanta to attract the attention of turn-of-the-century reporters and correspondents. "Hindoo peddlers" in general were numerous enough in sites of U.S. tourism such as Havana and the Canal Zone to attract such notice as well. These men have been "lost" to history in large part because popular understandings, expectations, and myths about immigration to the United States render them invisible or illegible. Hooghly's peddlers of Oriental goods did not do what we have been told immigrants have done since the eighteenth century: namely, give up their lives and homes in a distant land to seek a better life and a promising new future in an America that welcomed them with open arms. These men came to the United States on a thin edge between Indophilia and xenophobiathey arrived at a time in which fantasies of and goods from India were valued, even as immigrants from the subcontinent and other parts of Asia were being vilified, attacked, and excluded. For most Bengali peddlers, cities like Atlantic City, New Orleans, and Charleston were not final destinations, but places of opportunity for the sale of their villages' handicrafts, and were only a few among many nodes in a network that originated in South Asia and stretched beyond U.S. borders. Most remained sojourning itinerant peddlers, moving in and out of the country and from place to place. 
To this extent, Hooghly's peddlers had much in common with participants in other overseas commercial networks emanating from India in the late nineteenth century. Claude Markovits has provided the most extensive and detailed account of these Indian networks and estimates that the number of Indian merchants and financiers operating outside the subcontinent rose from a few thousand to a quarter of a million in the century between 1830 and 1930. Most of the growth occurred between 1880 and 1910 , precisely the period that traders from Hooghly began journeying outward from Bengal to find Western markets for their goods. ${ }^{92}$ What sets Hooghly's chikondars apart from their contemporaries is the extent to which they moved beyond British imperial circuits to engage the consumer desires of a nation that was just beginning to challenge Britain as a world power. While Sindhi merchants did eventually establish outposts in places like Kobe and Panama, their network largely followed the global expansion of the British; they sold their goods primarily within a circuit of British and European sites of travel and tourism. The Bengali peddlers, on the other hand, crossed deep into U.S. spaces-establishing markets for their "fancy goods" and "notions" both within U.S. borders and in areas such as Cuba and Panama, which had been recently occupied or colonized by the United States.

Although men from Hooghly were also moving through British colonial circuits-selling chikan goods in Australia and South Africa-theirs appears to have been the only overseas Indian trader network of their era to have established an extensive presence across U.S. sites of consumption and commerce. Hooghly's peddlers were thus involved in a curious imperial balancing act: they traveled in British steamships, along the supply routes of the British Empire, only to face American immigration officials as they crossed U.S. borders to sell Indian goods to U.S. consumers, who were eager to demonstrate their worldliness and class credentials as their nation became a power on par with Britain. Nothing in these movements was guaranteed. In India, the men were colonial British subjects, rather than citizens; their travels were allowed but subject to the oversight and restrictions of a ruling power. Their status in the United States was equally unsteady: as they entered the country each year, they did so through a narrow opening in an increasingly unfriendly immigration 
regime. As they discovered early on, they always ran the risk of detention and deportation. The trips they took were simultaneously made possible and made precarious by the power of Britain and the United States.

Ultimately, the transience of the Hooghly network's peddlers, the global nature of their movements, and the fact that their relationship to the United States was based largely on the vagaries of consumer demand all place these men at the margins of U.S. immigration history. They should, however, be no less important to our understanding of immigrant America. In their own day, these men were part of a much larger phenomenon in which tens of thousands of migrants from many regions of the world entered the United States as sojourning laborers. ${ }^{93}$ The fact that these workers came without an intention to settle, and most returned to their home villages, does not make their stories any less significant. Most of the Bengali Muslim peddlers, for example, spent extended periods of time in the United States, and, as a group, they constituted a continuous and visible presence in New Jersey, New Orleans, and other parts of the U.S. South over the course of more than three decades. As globally extensive as it was, their network was also embedded within U.S. communities of color, and members of the network married into these communities; some started families and spent the rest of their lives in the United States. This group's inclusion in the American story requires us to reimagine the structure of the early-twentieth-century migrant experience to recognize the kinds of transnational lives, connections, and dynamics we normally only associate with the present day. ${ }^{94}$ In the case of Hooghly's peddlers, this means not just tracing the global movements of these men, but also understanding the rootedness of their network in black neighborhoods in cities such as New Orleans and accounting for the women-both in these neighborhoods and on the subcontinent-whose lives and labor made the peddlers' work possible. 


\section{Between Hindoo and Negro}

Mose stood looking at his visitor. He was an old man ... dressed in tuxedo, tucked shirt and black tie. His small head and face seemed smaller under a turban of pale blue silk. Daddy Splane, Doctor of Spiritual Science. Mose knew at a glance the reason for the bizarre costume ...

"You ever lived Jim Crow?"

"Plenty. But I have ways of getting around it. I just put on my turban and pass as a Hindu. No trouble at all."

-William A. Owens, Walking on Borrowed Land

I

N her 1940 autobiography, A Colored Woman in a White World, suffragist and civil rights activist Mary Church Terrell told the story of a friend who had had a curious experience on a visit to the South. The friend, whom she described as an African American "real estate man who lives in Washington [DC]," had traveled to Charleston, South Carolina, to visit his sister. When he arrived, an exposition was being held and his sister "was very enthusiastic about an East Indian with an unpronounceable name who had astounded the [locals] with his wonderful feats of legerdemain." The man's sister brought him to see the East Indian magician and the two men immediately recognized each other. As it turned out, the two had been boyhood friends in Charleston; the "East Indian," Terrell wrote, had been "born and brought up as a colored boy in that very southern city" and was now posing, working, and traveling as a Hindu fakir. Now that the exposition was in Charleston, Terrell continued, the magician had taken to removing his 
garb at the end of each night to visit some of his local relatives, "until he grew so bold about it" that an African American friend "warned him to exercise more caution."

Terrell relayed this story to illustrate the strategies that African Americans developed over the course of many decades to "pass" in the segregated South-to cross the color line and temporarily, contingently, outwit the racial apartheid of Jim Crow. By the midtwentieth century, stories of passing circulated widely in African American communities; many of these stories focused on individuals who had successfully passed as white in order to access better jobs and accommodations, but for those who were darker skinned, posing as a "Hindu" or "East Indian" was a recurring and prominent theme. One national black magazine wrote that "some of the race's best folk tales are tied up in turbans and a half dozen other ways dark negroes 'pass' down south." The writers went on to cite the cases of Joseph Downing, who in the early 1900 secame the spiritualist "Joveddah de Rajah," and the Reverend Jesse Routte, "who traveled unmolested through the deep south . . . lived in a white [Mobile,] Alabama Hotel and ate in downtown restaurants simply because he wore a velveteen robe and a [turban] on his head." ${ }^{92}$

We will probably never know which black southerner first employed this ruse, first discovered that it was possible to move across the line between "Negro" and "Hindoo," from a denigrated to an exotic otherness, from an unacceptable to a nominally acceptable blackness, by simply donning a different costume, speaking in a different way, performing a different identity. It may have been that this individual witnessed men from India doing just this and saw that whites treated them differently, afforded them greater privileges of movement, or even sought them out for the goods they sold, the "wisdom" they bore, or the "magic" they performed. If such witness occurred, it could very likely have involved one of the Bengali peddlers. There were other Indians passing through the U.S. South in the late nineteenth century-performers with traveling circuses, merchant seamen moving on and off the waterfronts of New Orleans, Charleston, and Galveston. But the peddlers constituted the first longterm Indian presence on the streets of southern cities, and descriptions of these men in the act of selling their silks, rugs, and curios make clear that they had learned to perform a well-calculated Indianness. They ap- 
proached potential customers with a particular bearing, style of dress, mode of speech, and, it appears, even some replication of the servility of the imagined colonial subject. In this daily act, they validated and accentuated the ideas that Americans associated with "India" and "the East" and in so doing gave authenticity and value to the goods they sold. The men, in their "fezes," "frock coats," and "interesting blouses," were "courteous," "shrewd," "graceful," and "handsome"; they "enter[ed] stores and offices and cafes, with gentle persistency begging to show the contents of their packs"; they had "fathomless eyes," "brilliant smiles," and an "air of oriental mysticism" and were "so attractive ... that we will buy in spite of resolutions to the contrary."

When the Bengali peddlers began to set up their operations in New Orleans, Charleston, Savannah, and elsewhere in the 1890s, these cities were, in some ways, perfect locations for the men to enact their performances of authentic "Hindoo"-ness and to sell their exotic goods. As the phenomenon of middle-class tourism took hold in the United States, southern cities became popular winter destinations for white northerners, each locale offering its own "quaint" charms, customs, and cuisine, and each boasting bustling local markets, where travelers could buy gifts and mementos. New Orleans was a particularly suitable place for the chikondars to do business. By the final decade of the twentieth century, New Orleans was emerging as the South's preeminent tourist destination-as a place of unbridled pleasure and consumption.4 "India" and "the East," moreover, were already woven into the fabric of tourist New Orleans. Fantastical images of "the Orient" saturated the Mardi Gras parades of this period, while "Eastern" fantasies thrived within the walls of the city's brothels. When they plied their trade as "Hindoo peddlers" in New Orleans' markets and on its streets, Hooghly's chikondars could capitalize on a well-established set of notions about "the East."

However, the Bengali peddlers also arrived in the U.S. South at one of the most violent and perilous moments for its "colored" populations, as state and local governments were imposing legally_and whites were enforcing extrajudicially - a broad regime of racial apartheid. The 1890 s were marked by the passage of laws segregating transportation, schools, hospitals, and virtually every other arena of public life-and by a dramatic upsurge in lynchings of black men. The peddlers' trade 
required mobility, but for most men of their color, the stakes of movement across the South's dividing lines were high. "Travel and movement," writes historian Leon Litwack, "no matter what the distance, exposed blacks to a variety of risks and humiliations. Whether on the streetcars or railroads, at the ticket offices or in the ... waiting rooms, they faced Jim Crow restrictions and the insults and violence that often accompanied them." African Americans could move from "Negro" to "White" spaces only to perform a specific, circumscribed, and subordinate role-as a servant, a maid, a driver, a washerwoman. In this context, the Indian peddlers' politeness, servility, and self-exoticizing airs did a particular kind of work. This performance not only helped them to sell their goods, but also allowed them to move; their "Hindoo" dress and mannerisms gave the peddlers greater safety and mobility as they traveled by train from New Jersey through Virginia, North Carolina, Georgia, Alabama, and Mississippi to New Orleans; as they moved by foot from one neighborhood to another in New Orleans; or as they fanned out to sell their goods in other segregated cities: Atlanta, Memphis, Chattanooga, Charleston, Dallas. In an uncommonly direct reference to the peddlers' strategies of comportment and dress, The Hindusthanee Student noted in 1917 that the men had taken to donning fezes, a choice the writer saw as unusual for Muslims from the subcontinent, "principally as protection against prejudice."

However, the peddlers' exotic appearance could only shield them up to a point. As figures who could conjure popular fantasies of the East, they may have gained temporary passage through areas that were otherwise off-limits to men of color. But the dark hue of their skin ultimately determined where they would return at the end of each day, the type and quality of the houses in which they would live, the health conditions they would face, the public facilities they could and could not access, and the risks that attended their daily movements. They built their operation within the constraints of Jim Crow, shuttling back and forth between an Indianness they performed for their customers and a blackness they shared with New Orleans' and other cities' populations of African descent. Black neighborhoods thus came to play a central role in the Hooghly traders' operations; it was here that that their efforts were rooted and here that they gained neighbors, acquaintances, lovers, and wives. As 
much as their peddling depended on the movement of people, goods, and money through global circuits, these circuits needed to be anchored in particular cities. None of these cities was more important than New Orleans, the hub that gave Hooghly's peddlers access to consumers throughout the South, the Caribbean, and Central America, and within New Orleans they became anchored in the neighborhood of Tremé.

Over the course of almost four decades, the Hooghly network operated out of a series of households in this historic downtown neighborhood. The network gained a footing here as a core group of Bengali Muslim peddlers married local women of color. Some of these women were members of Tremés longstanding Creole of Color community while others had roots in the rural South and were of the first generation born outside slavery. While perhaps not acknowledged as such, these New Orleans women were also part of the Hooghly network, grounding it in the city through their local knowledge and connections and their daily labor to maintain boardinghouses, businesses, and families. By the 1920s, when the number of new peddlers moving through the network began to wane, Bengali traders had become integrated into the life of Tremé. Most lived just off the neighborhood's main commercial thoroughfare of North Claiborne Avenue, and many gave up the tourist trade entirely to sell clothing and other goods to black customers in their adopted neighborhood. In the ensuing years, their descendants and the memories of their presence would disappear into the history of black New Orleans.

\section{Hindoo Heavens and Jim Crow Streets}

The first records of the Bengali peddlers in New Orleans are scattered across the 188 os and 1890 s. Census enumerations suggest that Alef Ally, the first of the Bengali traders to settle in the city, arrived around 1885 . Ships' manifests record small groups of Bengali peddlers passing through New York on their way to New Orleans in 1890, 1893, and 1896. About eight members of the Hooghly network turn up in New Orleans marriage records between 1890 and 1903, and the first dozen children of these unions appear in the city's birth records stretching from 1892 to 1904. In these years, New Orleans was fertile ground for the peddlers' 
business. The fashion for "Oriental goods" had spread across the entire country, but in New Orleans the Bengalis found a manifestation of the Oriental "craze" in the local idiom of Mardi Gras that was grand in scale. In the final years of the nineteenth century, Mardi Gras was not only the centerpiece of local boosters' efforts to turn New Orleans into an international tourist destination, but also became the stage for some of the era's wildest spectacles of India and "the East."

Before the United States took control of Louisiana in 1803, Mardi Gras had been an event that the city's racially heterogeneous but predominantly Catholic population celebrated on the day before the beginning of Lent. In the latter half of the century, however, the city's new American political and business leadership-white Protestants with roots in the U.S. Northeast-moved to co-opt the yearly celebration. They began to use Mardi Gras to attract outside visitors and assert their own cultural heritage over that of the city's Catholic French, Spanish, and Creole inhabitants. ${ }^{7}$ Between 1857 and 1882 members of New Orleans' AngloAmerican elite formed a series of white male secret societies-the city's first krewes-to stage masked parades and balls on Mardi Gras. Each year, the Krewes of Comus, Proteus, Momus, and Rex designed costumes and built floats and, on Fat Tuesday, took over the main streets and thoroughfares of New Orleans with elaborate themed processions that referenced English and Greco-Roman history, literature, and myth. This meant that Mardi Gras parades were often multifloat illustrations of scenes from well-known English masterworks: Milton's Paradise Lost, Spenser's Faerie Queene, Dickens' Pickwick Papers. ${ }^{8}$

In the years that the Bengali peddlers established their operations in the city, the krewes partook in the larger fin de siècle fashion for "the East" by drawing liberally from Britain's large store of Orientalist literature. The Krewe of Comus had made the first gesture in this direction in 1868 by staging a Mardi Gras procession and ball enacting scenes from Thomas Moore's epic poem Lalla Rookh, about a Mughal princess who falls in love with a poet on the eve of her wedding. It featured, among other sights, the exotically costumed "princess" riding atop a life-size papier-mâché elephant. In 1882, not long before Alef Ally arrived in New Orleans, Proteus paraded a series of floats illustrating "Ancient Egyptian Theology," while the Krewe of Momus rode New Orleans' 
streets on floats depicting scenes from the Hindu epic The Ramayana. On average, at least one of the four major New Orleans krewes staged a procession and ball based on an "Oriental" theme every other year from 1880 to 1910. These included "Tales of the Genii," "Aladdin, or The Wonderful Lamp," "The Moors of Spain," "The Semitic Races," "Myths and Worships of the Chinese," "Shah Nameh," two versions of "The Mahabharata," and "Mahomet: Incidents in the Life of the Great Prophet."9

Two of the most elaborate of this era's Mardi Gras parades were staged by the Krewe of Proteus: 1889 's "Hindoo Heavens," which presented a series of floats based on the work "The Curse of Kehama" by the British Orientalist poet Robert Southey, and 1908's "Light of Asia," based on the epic poem by Sir Edwin Arnold telling the story of Buddha. ${ }^{10}$ Both were spectacular renditions of the most exotic ideas about India, its people, and its religions. "When darkness arrived," the Montgomery Advertiser reported of the 1908 procession, "twenty big floats of the Krewe of Proteus were wheeled out of their hiding places and began a night parade. These floats and the masked and costumed men riding on them illustrated the subject 'The Light of Asia.' Hindu beliefs and Buddhistic and Brahminical customs were portrayed, including allegories of Yasodhara the Fair, the dancers of Indra's temple; The Lords of Light; Parihga and Mano; Kama the King of Passions, Mara and the Tempter; and The Abode of the Rishis. A bhodi tree, some huge dragons and monsters without names were portrayed on the floats." ${ }^{.11}$ Year after year, thousands of locals and visitors came out to line the Mardi Gras parade routes, and in procession after procession, New Orleans' Anglo-American krewes filled the imaginations of these eager spectators with fantastical ideas about "the East." The lines between India, China, the Middle East, and North Africa blurred, as did those between Islam, Hinduism, and Buddhism. All were part of a single Oriental imaginary - a store of exotic notions upon which the Bengali peddlers could draw each day they stepped out to sell their goods.

The remaking of Mardi Gras into an Anglocentric tourist spectacle was just one part of a larger transformation that New Orleans' white leadership was imposing on the city during the years Bengali peddlers put down their roots. Over the same two decades in which Mardi Gras was saturated with "Oriental" imagery—the same period in which the 
men from Hooghly and Calcutta established households in the city and found sites, routes, and customers for their goods-the daily life and racial geography of New Orleans were being remade by Jim Crow. From the time that the Anglo-Americans arrived from the North to take control of New Orleans in 1803, they began what would be a decades-long, uneven, but unrelenting process of "Americanizing" the city. They first pushed to marginalize and displace New Orleans' existing "white Creole" elite-a group who were of French, Spanish, and mixed FrenchSpanish ancestry. New Orleans' free persons of color, or Creoles of Color, were also a threat, particularly after the end of the Civil War. Although less powerful than the white Creoles, the city's gens de couleur libre had carved out a considerable cultural and political presence in Tremé and other neighborhoods on the downtown side of New Orleans and included a segment of relatively prosperous tradespeople and craftsmen.

After men of color swept into Louisiana's state legislature over the period 1868-1872, the Anglo-Americans mounted an often violent campaign to reassert themselves and prevent the leadership of the free person of color community from establishing lasting political power. ${ }^{12}$ By the 1880 s, white Americans had regained control of the state government, and in 1890, around the time that the first Bengalis settled in New Orleans, Louisiana's legislature began to construct the legal edifice of Jim Crow. Their first step was a law that required railroad and streetcar companies to provide "separate accommodations for the white and colored races" and prohibited "colored" passengers from riding on cars or in sections designated for whites. Although members of New Orleans' free person of color community challenged the Separate Car Act, the U.S. Supreme Court, in its Plessy v. Ferguson decision, upheld the law's constitutionality. This cleared the way for Louisiana to enact a series of other segregation laws as well as a new state constitution that effectively disfranchised the state's citizens of African descent. ${ }^{13}$

Over the next several decades, Jim Crow changed the social and physical geography of New Orleans, and Tremé-the seat of Creole of Color power-was particularly affected. At the end of the nineteenth century, Tremé, was still a heterogeneous neighborhood. The neighborhood's Creole of Color community was broadly varied across lines of class and 
skin color; it included gens de couleur libre who were dark skinned and others who, like Homer Plessy, were light enough to pass as white. Some engaged in manual work, while others owned businesses, practiced professions, or edited newspapers. Tremé was also home to some of the thousands of Americans of African descent who had migrated to New Orleans from other parts of the South in the years following Emancipation, and to a smaller number of working-class European and other immigrantsIrish, Italian, German, Syrian, and Chinese.

Anglo-American rule had already begun a process of flattening New Orleans" heterogeneity into "a rigid, two-tiered structure that drew a single, unyielding line between white and nonwhite." This process accelerated from the post-Reconstruction era into the 1920 s and 1930 s as segregation and disfranchisement politically weakened and isolated Tremé's inhabitants. Tremé was made into a "negro district" in the image of others across the segregated South and the rest of the United States-its population excluded from power, its housing and infrastructure neglected, and its residents and borders policed. By the turn of the century, Tremé was one of two such areas near the center of New Orleans. The other was not far away; across Canal Street on the uptown side of the city, many of New Orleans' recent black American migrants were concentrated in a small area of low-grade housing referred to as "back of town" or "the Battlefield." The lines dividing both these neighborhoods from "white" parts of New Orleans became more pronounced as the city passed residential segregation ordinances and as the expansion of streetcar lines and the drainage of swampland opened up new neighborhoods and spurred white flight out of the city's core. ${ }^{14}$

The stakes of the post-Reconstruction racial order were made clear by an event that occurred soon after the first group of Bengali peddlers established their footing in New Orleans. On July 23, 1900, a young African American man was questioned by New Orleans police. The man, Robert Charles, had recently made his way to New Orleans from rural Mississippi. He ended up working a range of odd jobs while becoming active in an association advocating African American migration to Liberia. Charles had, according to later accounts, been enraged by the recent killing of Sam Hose, a young black man roughly the same age and generation as Charles, who had been brutally lynched by a white mob in 
Georgia. New Orleans police officers questioned Charles because he was seen sitting on the porch of a white family's house on a racially mixed block on the uptown side of the city. As the confrontation quickly escalated, Charles pulled out a pistol and fired, then ran to his apartment, and as the police and a crowd of thousands of white New Orleanians closed in on him, he opened fire with a rifle, killing seven men before being killed himself. New Orleans was now engulfed in antiblack violence: "For four days, mobs surged through New Orleans, seizing control of downtown sections, killing at least a dozen black people and injuring many more, and destroying black property," including the city's leading school for children of color, the Lafon School, which was burned to the ground. ${ }^{15}$

Six weeks before this incident, U.S. Census takers had recorded ten members of the Bengali peddler network residing on St. Louis Street, in downtown New Orleans. July was high season for the New Jersey seaside resorts, and it is possible that many of these men-Solomon Mondul, Abdul Subham, Bahadoor Ali, and others-had left to work the boardwalks of Atlantic City and Asbury Park not long before New Orleans erupted in racial violence. A smaller number, however, were almost certainly present to witness the rampage. Sofur Ally, for one, had just got married to a local Creole woman days before the riots broke out. And those who traveled to New Jersey for the season returned in the fall to a New Orleans still reverberating from the events of July.

It is difficult to say exactly what the peddlers experienced in the ensuing years, how they were regarded and treated as men of color operating within a volatile racial order. Even the most exoticizing descriptions of Bengali peddlers in turn-of-the-century U.S. newspapers-and of the Bengali, Punjabi, and other Indian seamen who were now beginning to appear with frequency in U.S. ports-focused in on the men's complexion and tried to place them according to the United States' binary racial logic. One 1900 story about Indians in the sailors' quarter of New York City stated that these men were "all so dark as to be taken easily for Negroes, but their features are Caucasian and their hair is straight, stiff, and wiry." It described their character in terms that drew on notions of both Asian "inscrutability" and African American "criminality," saying that they "are peaceable and orderly up to a certain point and then they 
lose all self-control and generally resort to the knife." Another story, focusing on a group of Bengali peddlers who were working on the streets of Atlanta, Georgia, declared that these Indian men were "not like American Indians, of course, but look like Mexicans, only three shades darker." In this case, the peddlers were represented, as African Americans often were in the white press, simultaneously as wily and dim-witted. ${ }^{16}$ Government documents from the same period reflect a certain confusion about the "color" and "race" of the Bengali peddlers. In 1900 and 1910, federal census takers marked most of the men "Black," others "Mulatto," and a few "White," before a supervisor often scratched "Hin" for Hindu over the top of the original classification. During the First World War, draft registrars described the peddlers" "race" variously as "Black," "White," "Oriental," "Turkish," and "Malaysian." The officials who processed a handful of the Bengalis' passport applications in the 1910 s mostly described their "complexion" as "dark" but in one case wrote "copper," in another "ruddy," and in another "light."17

There was clearly a difference between these official classifications and the lived experiences of segregation the peddlers faced. While the Bengalis may have benefited from the kind of ambiguity that is apparent in official attempts to classify them, their position within the racial order ultimately appears to have been provisional and uncertain. Like the distinctions between "Creole," "free person of color," and "negro," the various ways of describing, categorizing, and distinguishing these Indian peddlers meant little when it came to the most basic aspects of Jim Crow. The Bengalis' darkness, no matter what shade or category, made them vulnerable to individual acts of violence and was a deciding factor when they sought out family homes, boardinghouses, neighborhoods, and communities in which to live.

Two of the only records we have of the Bengalis' direct confrontation with Jim Crow make clear the contingency of their position in the segregated South. In the opening years of the twentieth century, a small number of Bengali traders began naturalization proceedings in various southern cities. These included Alef Ally, Sofur Ally, Abdul Hamid, and Abdul Jobber Mondul in New Orleans and Mohamed Kauser, Abdul Aziz, Elahi Baksh Mondul, Abdul Rohim Mondul, Abdul Haq Mondul, Mohammed Idris, and Syed Abdul Ganny in Charleston. ${ }^{18}$ The 
most well-known naturalization case from this group is that of "Abba Dolla," a trader of Afghan descent who became a member of the Hooghly network in Calcutta, worked the New Jersey summer resorts in the 189os, and then settled in Savannah around the turn of the century. There, Dolla became a local supplier, receiving shipments of embroidered silks and cottons through the Savannah customhouse, and then distributing these goods to other members of the peddler network to sell throughout the city and its vicinity. It is difficult to locate Abba Dolla in shipping, census, and other records because his name was either changed or mistransliterated in the process of applying for citizenship, but it appears that Dolla was the same member of the network who traveled through New York to New Jersey several times in the 1890 os under names recorded as "Obidullah" and "Abad Ally." Dolla filed a Petition of Intention to Naturalize in Savannah in 1907, and then in 1910 submitted his application to naturalize, along with supporting statements from two witnesses. At the time he went up before a judge in the Federal District Court in Savannah in 1910, people of only two "races" were allowed to become U.S. citizens_-"white persons" and "persons of African ancestry" - and like a handful of other East Indians in the years immediately before and after him, Dolla applied for and was granted citizenship as a "white person." 19

Immigration historians have described Abba Dolla's case in this context; it is understood as one of a number of instances in the early twentieth century in which immigrants from India successfully "claimed whiteness." The details of both his case and his daily life in segregated Georgia, however, present a less clear picture. Having determined that Abba Dolla had followed the correct procedures in his application for citizenship, the judge examining Dolla held that the only issue to determine at his hearing was "whether or not he was a white person within the meaning of [the] naturalization laws." To this end, Dolla presented an argument in several parts: he described his ancestry-he stated that he was born and raised in Calcutta and was of Afghan descent; he cited the case of Abdul Hamid, another Calcutta silk peddler with whom he had entered the country in 1894 , and who had been naturalized as a "white person" in 1908; he testified that he was the owner of a plot in Savannah's white-only cemetery; he offered to produce a series of (presumably white) 
leading citizens to attest to his good character-"the deputy collector of the Port at Savannah, certain merchants of the city, one of the attaches of the United States court"; and he offered to produce "a leading white physician" who had once operated on him for appendicitis and who would confirm that he was "of pure Caucasian blood." The judge heard all this and first seemed concerned to determine that Dolla had not developed any social affiliations with the black community. Ultimately, however, the judge called no witnesses; instead he relied on a close examination of Dolla's skin, asking the silk trader to roll up his sleeve and noting that while his face and hands had been darkened by the sun, his unexposed skin was "several shades lighter . . . and was sufficiently transparent for the blue color of the veins to show very clearly."20

Although Dolla was granted citizenship, this was not a larger indication that "East Indians" were widely considered or treated as "white." The U.S. government in fact vigorously opposed Dolla's naturalization, as it had in other similar cases, sending an assistant U.S. attorney, Alexander Ackerman, to challenge its own federal district court judge at Dolla's hearing. Ackerman presented an argument that failed to sway the judge, that Dolla, as an Asian, was not a "white person" and was therefore racially ineligible to become a U.S. citizen. The method that the regional district court judge used to determine that Dolla was "a white person" was unorthodox even for 1910-more in line with the daily practices of southern segregation than with any legal precedent. His judgment also belied the subjectivities and inconsistencies of an early-twentieth-century naturalization system that put decision-making powers in the hands of a range of lower federal court judges. There were opportunities but no guarantees for members of the Bengali network seeking citizenship in southern courts. While a few of Abba Dolla's fellow peddlers may have also had skin "sufficiently transparent for the blue color of the veins to show," any number of them could have failed the visual inspection to which he, a presumably lighter-skinned man of Afghan descent, had been subjected by this particular district court judge. Many would have also failed to convince this judge that they had not developed affiliations with the local "colored" population. ${ }^{21}$

In truth, Dolla's own relationship to Savannah's black community was less clear-cut than he presented and than the judge chose to see. For 
all the white citizens he offered to present at his hearing, Dolla's two official witnesses, who had, in sworn written affidavits submitted with his application, confirmed his presence in Savannah over the previous three years and attested to his good character, were both African American men. This suggests that Abba Dolla had been in closer proximity and developed greater familiarity-if not also closer ties-with members of Savannah's black community than with its white citizens. And although the judge at Dolla's hearing determined to his own satisfaction that Dolla pursued his trade "among whites and blacks indifferently" and that he lived together with "several of his countrymen" and only maintained "relations of a social nature" with "those of his own nationality," federal census records show that the Bengali peddlers operating in Savannah all lived within black neighborhoods or on predominantly black city blocks. In 1900, the single member of the Hooghly network who appeared in the census in Savannah was Abdul Barrick, who was renting a room from a widowed African American laundress and living with her three children and niece. The 1910 census recorded one Bengali group household in Savannah, and it was located in the same workingclass African American area on the east side of the city. ${ }^{22}$

Abdul Hamid, whose successful naturalization Dolla cited as a precedent, also appears to have lived a more complex relation to blackness and to the black community than his naturalization as a "white person" would suggest. By the time he applied for naturalization in New Orleans in 1908, Hamid had already been married to a local Creole of Color woman for eight years, and in the years that followed he lived and worked within the "negro" community in the heart of Tremé. ${ }^{23}$ It is of course impossible to know how individual members of the Hooghly peddler network saw themselves in relation to color, "race," and the racial order that surrounded them in the South, but there is enough evidence to suggest that for many, naturalization was a strategic move to give greater stability to their business pursuits rather than an identification with white supremacy and a disavowal of African American and Creole neighbors, acquaintances, and extended families. And they would have clearly understood after even a short time in the Jim Crow South that legal citizenship was not equivalent to full citizenship, that racial determinations were made not only in the courts where 
they sought to naturalize but also on the streets where they plied their trade.

If, in the courts, the subjectivity of racial judgments could work in the peddlers' favor, in this other arena of their daily lives, the subjective execution of segregation could just as easily turn against them. This is brought home in another incident involving a Bengali on the streets of New Orleans in 1922. The case of Abdul Fara is recorded in The Negro in Louisiana, an unpublished manuscript authored by the African American poet and historian Marcus Christian, based on research he directed as head of the Works Progress Administration's Louisiana Negro Writers Project in the $1930{ }^{2}{ }^{24}$ In a chapter describing the evolution of Jim Crow laws in post-Reconstruction Louisiana, Christian wrote that by the 1920s, a variety of New Orleans residents, including "persons of colored races such as Japanese, Chinese, American Indian, Puerto Rican, Philipinos [sic]," as well as persons whom he described as "dark whites . . . Turks, Indians, and Spaniards," and some number of "lightskinned Negroes," were all regularly seating themselves in the "white" section of the city's segregated streetcars. The conductors of these streetcars, he continued, normally let these riders be, "having been warned of the costly consequences of mistaken racial identity." In Abdul Fara's case, however, the conductor was not the problem.

Fara boarded a streetcar on Canal Street and took a seat in the last row of the "white" section, next to a white World War I veteran named Fitzhugh Davis. After two blocks, Christian writes, the conductor left the back of the streetcar and came to investigate. He approached Abdul Fara and asked him "whether he was a white man or Negro." Fara claimed neither identity; he "replied that he was a native of Calcutta, India, whereupon the [conductor], apparently satisfied, returned to his place on the platform." Soon afterward, however, the white passenger sitting next to Fara took matters into his own hands. After an exchange of words, he grabbed the "screen" that marked the dividing line between the "white" and "colored" sections of the streetcar-a heavy wooden sign with two thick metal prongs that was slotted into the back of his seat-pulled it out, and attacked Abdul Fara with it, striking him twice over the head. When Fara later brought suit against Davis, the white judge hearing the case declared that it was reasonable that Davis might have thought Abdul Fara 
was a "negro" and that he was thus justified in having become incensed at Fara's riding in the "white" section of the car and in striking him. The judge held in favor of Fara's attacker and ordered Fara to pay the costs of the court. In an arena in which individuals were empowered to enforce white supremacy in its multiple daily manifestations, the Bengali peddlers' access to white spaces and privileges was always going to be provisional and subject to revocation at a moment's notice. These spaces may have provided them with customers who would buy their goods, but black neighborhoods were where the Bengalis became rooted and built their lives.

\section{Into Tremé}

The first federal census of the twentieth century, conducted in June 1900, gives us a snapshot of the Bengali peddlers at work across several states. Heroo Shaikh, who traveled from Calcutta to New York with ten other members of the network in 1896 , was now living in a lodging house for southern black migrants in Pittsburgh. Abdul Latif was renting a room from an African American family in Cleveland, Ohio, and Rahim Bux lived in an all-black neighborhood in the seaside town of St. Augustine, Florida. Abdul Surcar was peddling goods in Houston, Texas, where he had married a young African American woman named Sadie, and Bell Ali was living as a dry-goods peddler in a predominantly African American neighborhood in Galveston, Texas. In Charleston, seven members of the network were living in black family homes or neighborhoods, and three had married local black women. In Atlantic City, where segregation was enforced by practice rather than by law, the Bengalis' place was clear by contrast to that of their Syrian competitors: while Syrian Oriental goods peddlers had settled in white lower-middle-class areas among members of Atlantic City's permanent population, the Bengali men were living with other seasonal workers of color-stewards, cooks, chambermaids, bartenders, laundresses, and musicians - in a segregated black section of town. ${ }^{25}$ At the turn of the century, everywhere the Bengalis peddled their goods, they lived in working-class African American homes, apartment buildings, or neighborhoods. ${ }^{26}$ 
New Orleans was no different. From the moment the Bengali peddlers arrived in the city, they lived among its residents of African descent-both southern black migrants and Creoles of Color. Over the course of decades, they appear to have experienced alongside these groups the encroachments and effects of the city's implementation of Jim Crow. Between 1895 and 1930, the Bengalis made their homes almost entirely in Tremé. Some of the men established group households and boardinghouses in a handful of neighborhood buildings that subsequently provided shelter for dozens of fellow members of the Hooghly network-cousins, uncles, nephews, sons, and co-villagers. Others married into local New Orleans communities, starting families with Creole of Color women and women connected to the more recent African American in-migration. Still others moved from one residence to another over decades spent cycling in and out of New Orleans but always within the bounds of Tremé.

In these years, the Bengalis' lives became entangled in the neighborhood's transformations. As New Orleans' leadership implemented Jim Crow and opened up other parts of the city, as many of Tremé's European immigrant residents moved out, the Bengalis became more integrated into the neighborhood. ${ }^{27}$ Tremé experienced two major shifts in its geography and make-up. First, just one year after the Plessy decision, New Orleans' aldermen carved thirteen poor, largely black residential blocks out of the southwest corner of Tremé in order to create the city's new sex district. Then, in the 1910 s and 1920s, as Canal Street and other commercial areas across New Orleans came to be restricted to whites, a new black cultural and commercial core formed along the wide tree-lined boulevard of Tremé's North Claiborne Avenue. New Orleans' Bengali peddlers moved with both these shifts. In the 1890s, the first group of men from Hooghly and Calcutta established their operations in the section of Tremé that was to become, before their eyes, the Storyville sex district. Some of the peddlers remained here as local residents were pushed out, and others followed displaced residents of color to the blocks just outside the District. The Bengalis were here at Storyville's edges as the neighborhood's brothels, bars, and barrelhouses rose and fell. By the 1920 s and 1930s, the handful of Indian peddlers who remained in New Orleans moved again - this time into the new heart of 
black Tremé along North Claiborne Avenue, where they sold textiles, embroidery, and ready-made clothing not to tourists, but to the local residents of the neighborhood.

Bengali peddlers of silks started making trips from New Jersey to New Orleans between the mid-1880s and the early 1890 os. The first members of the network to do so-Alef Ally, Moksad Ali, Jainal Abdeen, and Aynuddin Mondul-all arrived in New Orleans during this period. By 1895, another group had joined them-Solomon Mondul, Abdul Subham, Sofur Ally, and Majan, Eshrack, and Bahadoor Ali. Most of the men found accommodations on a block of St. Louis Street between Marais and Tremé Streets, near Congo Square and a stone's throw from St. Louis Cemetery No. 1. The two residences they rented, 1420 and 1428 St. Louis Street, were on a block of two- and three-story wooden structures built in the simple "shotgun" style common in much of this section of New Orleans. Some of the streets in the surrounding area were dirt, others were gravel, some were paved with cobblestones, and still others with wood planks. This was a vibrant corner of Tremé. The Bengalis' neighbors were working-class and primarily of color, a mix of families and unmarried adults. The families were often extended and multigenerational, with parents, grandparents, adult siblings, in-laws, and children living under the same roof. There were also a few white households interspersed through the area tied to various waves of European immigration: German, French, and Irish. The neighborhood included the Union Chapel-an African Methodist Episcopal church-as well as a "Negro public school" and a handful of black lodges and meeting halls. Many of the neighborhood's women and men, like the Bengalis, would have fanned outward each day to go to their jobs in other parts of the city-as construction workers and day laborers, as dockworkers, porters, and cooks, and as laundresses, maids, and house servants. ${ }^{28}$

In 1897 , this part of New Orleans became the first in the city to experience the post-Plessy regime of residential segregation. That year, the city passed ordinances that made prostitution illegal everywhere in New Orleans except two specified areas; the larger of these two, which would come to be known as "Storyville," or simply "the District," encompassed the thirteen blocks bounded by St. Louis, Basin, Customhouse, 
and Robertson Streets, including at its edge the block where the Bengali peddlers were living. As Alecia P. Long has argued, the legal delineation of these blocks was not an act of racial segregation per se. Yet in carving "the District" out of this poor, predominantly black locality, she writes, "city leaders implied a rough equality between its population of "lewd and abandoned women,' . . . and the African Americans who lived, went to school, and worshipped in the neighborhood." The disruption of the latter group's existing community was of little importance to those who penned the ordinances, if the features of this community were even legible to them. Both populations-the city's sex workers and the more than two thousand existing residents of this section of the city-were to be spatially separated from "respectable" New Orleans; both were to be controlled and contained..$^{29}$ In the years that followed, the logic and rhetoric that had supported the creation of Storyville would be extended: "Segregationists would argue that, like prostitutes, African Americans should be separated from respectable whites because of their [supposed] propensity toward disorder, sensuality, immorality, filth, and disease." ${ }^{930}$

Soon after Alef Ally, Solomon Mondul, and the other Bengali chikondars settled into this area, they would have seen their street and the surrounding neighborhood go through a transformation. In 1900, three years after the legal delineation of the sex district, the U.S. Census recorded a number of people in the immediate vicinity of 1420 and 1428 St. Louis Street who were clearly connected to Storyville's dance halls, saloons, and brothels. But, at this stage, a significant portion of the area's population still consisted of Creole of Color and black American residents who had little or nothing to do with the District's businesses. They included teamsters, dockworkers, railroad workers, slaters, sailors, day laborers, and likely some number of the women listed as cooks, washerwomen, and maids. ${ }^{31}$ This changed quickly after 1900. Between 1900 and 1910, the owners of buildings in the area-who were usually whites who lived in other parts of the city-took to subdividing their residential properties into multiple single-room "cribs"- spaces that they could rent out in two shifts a day, at a high premium, to the neighborhood's sex workers. Although it was on the outer edge of Storyville, St. Louis Street was not immune to this trend. By 1908, seven of the buildings on the 1400 block had been converted into sex workers' cribs. 
This included 1420, the building where seven members of the Hooghly network had lived just a few years earlier, and 1426, the building next door to Alef Ally and his two daughters. By 1914, in addition to the seven cribs, the 1400 block featured a saloon on each corner, and Alef Ally's building was one of only two residential dwellings left on the block. ${ }^{32}$

This trend appears to have displaced much of the area's remaining working-class population, pushing them to the undesirable blocks just outside the borders of the sex district or to other parts of the city. ${ }^{33} \mathrm{Un}$ like many of his former neighbors, however, Alef Ally did not move from the area, and his was the block to which increasing numbers of Bengali peddlers came to live in the 1910s. When the census was conducted in April 1910, Ally was fifty years old and a naturalized citizen, and had been a resident of New Orleans for more than half his life. He had now turned the building at $1428 \mathrm{St}$. Louis Street into a boardinghouse for other members of the Hooghly network. While Ally's occupation was listed as "merchant," he was also recorded as head of a household that included his younger daughter, Viola, a sixty-five-year-old "mulatto" woman named Celestine Gardner, and twenty-one Indian peddlers. The peddlers included a small number of older men who were veterans of the Hooghly network, but most were recent arrivals to the United States. ${ }^{34}$ The building at 1428 St. Louis Street appears to have become a key part of the New Orleans operation, where older members of the network introduced younger members to the city and the trade. In the decade between 1904 and 1914, a series of younger peddlers from Hooghly villages declared at their Ellis Island inspections that the St. Louis Street residence was their final destination and named a group of senior Bengali peddlers-Fazleh Rahman, Abdul Barrick, Monsur Ali, and Moksad Ali-as the "relations" whom they were joining there. ${ }^{35}$

What did these men from Babnan, Chandanpur, Sinhet, and Alipur make of the world around them? What did they make of the changes that were occurring on their block and in the neighborhood beyond St. Louis Street in the months and years after the creation of the sex district? In Calcutta, they were connected to a neighborhood not unlike the one Storyville was becoming. The "vice" in the area around St. Louis Street also was not new. There were a significant number of brothels, saloons, and dance halls in the area even when the first group of Bengalis moved 
to this part of New Orleans in the 1890 s. $^{36}$ This is likely the reason they were able to find affordable accommodations on St. Louis Street in the first place. One nearby property owner testified in an 1897 court case that "she had tried on several occasions" to rent three of her houses on St. Louis and Franklin Streets " "to respectable people, but they wouldn't live in the neighborhood,' so she rented them to prostitutes or questionable characters instead." ${ }^{\prime 37}$

In the years after 1897 , the Bengalis would have seen the sex trade take over their area. The cribs and brothels on the blocks around them became an integral part of New Orleans' growing tourist economythese establishments were the illicit side of the same phenomenon of warm-weather "pleasure seeking" that had drawn the first members of the Hooghly network to the city. ${ }^{38}$ Each night this area was inundated with hundreds of men-both locals and visitors—on their way into and out of sex and drinking establishments in search of pleasure, power, and fantasy. And the growth of the sex industry was not the only change occurring in the area. The brothels and saloons were full of music: particularly ragtime and the evolving style that would become jazz. So were the large halls that were all a stone's throw from St. Louis Street-Globe Hall, Economy Hall, Equity Hall, Friends of Hope Hall. From the time they arrived, the peddlers would have regularly heard the sounds of brass bands playing funeral marches as they passed Alef Ally's boardinghouse en route to St. Louis Cemetery No. 1 half a block in one direction or St. Louis Cemetery No. 2, two and a half blocks in the other. Now they would have also heard the sounds of the new music pouring out of neighborhood establishments each night. ${ }^{39}$

Their black and Creole neighbors did not all respond to these changes in the same way. A group of neighborhood residents-the leadership of Union Chapel Methodist Episcopal Church and some of the six hundred members of its congregation-fought to prevent the creation of the sex district in 1897. Black women and men who had attended the church all their lives were now being priced out of their neighborhood homes as landlords doubled and tripled rents in anticipation of the area's conversion to sex work. The chapel's minister argued that the creation of the vice district would "destroy the value of the [church] property for the purpose for which it was intended ... as a place of 
worship." ${ }^{40}$ The courts' rejection of this legal challenge demonstrated how little power local residents of color had in the face of the city's expanding regime of residential segregation. ${ }^{41}$ After these local residents' claim was denied, however, other New Orleanians of color engaged with the District as a source of work. Besides many of the sex workers and a small number of Storyville's madams, the neighborhood's businesses employed hundreds of entertainers and service workers, who were predominantly African American and Creole: "two hundred musicians, about five hundred domestic workers, and a hundred fifty saloon employees," according to one account. ${ }^{42}$

It is impossible to know where the Bengali peddlers were on the spectrum between those who objected to and fought Storyville and those who accepted and partook in its daily business. It is possible that some of the men from Hooghly, like the members of Union Chapel's African Methodist Episcopal congregation, objected to the trade that was flourishing on their doorstep and on the streets all around them. However, for the veterans of the peddler network - even those from Hooghly's villages-their experiences in Calcutta, and later London, Liverpool, New York, and elsewhere, would have made them accustomed to areas like the one springing up around them. They were also businessmen who may have recognized the District as a site for their own trade. It is beyond the scope of archives and popular memory to know for certain if the Bengalis sold within Storyville. What we do know is that the kinds of goods these men purveyed were prominent throughout the sex district. The fantasies of India and "the East" that New Orleans' elite white krewes paraded through the streets during Mardi Gras each year were also manifest in Storyville brothels where "Oriental dancing girls" regularly performed. These performances involved women who were likely Creole, African American, Jewish, or Southern European who dressed in scant "Oriental" fabrics and were surrounded by rugs and wall hangings meant to evoke the imagined harems of Arab, Persian, or Mughal emperors. ${ }^{43}$ Later advertisements for the goods that Bengali peddlers sold in New Orleans list precisely the kinds of items that would have been used to construct such sexualized fantasies of the "East"- "real lace [and] hand embroidered shawls from faraway India" along with "negligee waists, silk lingerie, undergarments, hosiery, [and], camisoles." ${ }^{44}$ 
Oriental goods also appear to have played the same function within the interiors of Storyville brothels as they played within the mansions of the United States' elites-as markers of worldliness and class distinction. The madams who ran the District's large upscale brothels along Basin Street emulated the lavish interior designs that were in fashion among European and American upper-class women of the late nineteenth century. The Arlington, run by Josie Arlington, rivaled Bertha Palmer's home in its opulence; it boasted "a Turkish Parlor, a Hall of Mirrors, a Japanese Parlor, a Vienna Parlor, an American Parlor," but also added rooms that were specific to the building's primary use: "seemingly countless luxury 'dens' and 'boudoirs,' . . with quantities of wall hangings, chandeliers, drapes, rococo furniture, afghan spreads, [and] oriental, deep-pile rugs. ${ }^{95}$ Houses like The Arlington appear to have set a standard that less exclusive brothels were quick to follow. Photographs from the period, including those by E. J. Bellocq, show brothels thickly decorated with "Oriental" rugs, scarves, cushions, tablecloths, and tapestries. ${ }^{46}$ The Bengali peddlers on the edge of Storyville had access to such goods and would have found lucrative business among the District's madams, who were known to local traders for their tendency to make a show of wealth and luxury. "[M]erchants 'sold high' to owners of maisons de joie and madams prided themselves on their willingness to "pay the price." "47

Whether they were selling within Storyville or confining themselves to New Orleans' tourist trade, by 1910 the number of Bengali peddlers operating in the city had grown significantly. The federal census recorded more than fifty chikondars residing in the city in April of that year, but an Indian account suggests that the number of Bengalis moving through New Orleans may have actually been in the low hundreds by this time. ${ }^{48}$ While a number of the earliest peddlers had married in New Orleans by 1910, and others appear to have returned to their villages in India, another group had chosen to live a different kind of life; they settled on neither end of the network, but instead remained mobile, living and working in the company of other men. These older chikondars traveled and plied their trade together in the same pairs and small groups over many years and across the full breadth of the network. They also appear to have been the members of the network who shepherded younger 
peddlers through its circuits, initiated them into its workings, and maintained a shifting set of households for the network in key cities.

Between 1900 and 1910, a group of these network veterans-Solomon Mondul, Abdul Aziz, Tazlim Uddin, Abdul Goffer Mondul, Abdul Majid-followed Storyville's displaced working-class population into the blocks of houses just outside the borders of the sex district. ${ }^{49}$ The peddlers crowded into the homes here; between four and a dozen men lived together at each address, in simple spaces that were rarely larger than eight hundred square feet. ${ }^{50}$ Although they spread out across the city to sell their goods each day, here in these houses they shared the domestic and intimate aspects of their lives, cooking and eating together, washing and cleaning, likely sharing beds, caring for those who fell ill, helping each other navigate the challenges of their daily lives, and spending leisure time with one another. In one of the few accounts that exists from this era of the Bengali peddlers at rest, a visiting Indian student wrote that "here in the South, they live in groups [and] you often notice them in their pajamas, sitting at ease, playing cards and gossiping, mostly about oldfashioned things. ${ }^{951}$

It is not clear how much these men interacted with the others around them, but there was a tenor of daily experience that they would have all shared with one another. The character and landscape of the neighborhood were similar to those of St. Louis Street before the creation of Storyville. The Bengalis' neighbors were predominantly of colorclassified on census enumerations as "Black" and "Mulatto"-and the buildings around them included many multigenerational, extendedfamily households that were often female led. These neighbors included washerwomen, porters, riverboat and ocean-bound sailors, railroad and levee workers, a "wine rectifier," and a barber. The streets were still unpaved and the houses were packed closely together-long, one-story shotgun homes made of wood and tin, a door every ten feet. When it rained hard, the streets here would have run with mud and sewage. When New Orleans experienced its frequent outbreaks of diseases such as tuberculosis, smallpox, and yellow fever, they spread fastest in overcrowded areas like this, and the results are evident in the death certificates of those who died here in the opening years of the century, including the handful of Bengalis who passed during these years: Jainal 
Abdeen, dead at thirty-three in 1900, Bahadoor Ali, dead at forty-two in 1906, Moksad Ali, dead at forty-six in 1918, all from tuberculosis. ${ }^{52}$ In addition to these conditions, most of the men from Bengal shared with their neighbors a set of social constraints-varying levels of literacy and education, marginal economic status, and dark skin-which relegated them to some of the most neglected housing in the city. ${ }^{53}$

Of the group of Bengali residences that appeared on the federal census in 1910, two stood out from the rest, as they were farther from the edge of the sex district and several blocks deeper into the center of Tremé. Significantly, these were the homes of two of the Bengali men who had married local women of color. Joseph Abdin was living with his wife, Viola, an African American woman from Mississippi, four blocks east of the District, on Orleans Avenue. They had a household of ten that included Joseph and Viola's two children and Viola's mother, sister, three nephews, and niece. Sofur Ally was living with his wife, America, a New Orleanian of Creole and Cuban descent, and their three children a few blocks farther up Orleans Avenue, near the corner of North Derbigny. Both of these men were near commercial areas that catered not to white tourists but to the predominantly black working-class residents of the neighborhood. Abdin's residence faced the covered Tremé Market, and Ally's was one block away from the emerging "Negro" shopping and entertainment district on North Claiborne Avenue. In 1910, Abdin and Ally were at the front edge of a shift that New Orleans' Bengali peddlers would make over the next decade and into the 1920s, as anti-Asian immigration laws made the crossing of U.S. borders more difficult for the peddlers and as New Orleans' commercial segregation became more stark. ${ }^{54}$

The group households that Alef Ally, Solomon Mondul, and others had established on the outskirts of Storyville continued to function as hubs for a transient population of scores of Bengali peddlers at least into the late 1910s. The network's global activities appear to have been at their height, however, around 1914. The same Indian student who described the lives of Hooghly peddlers in the South in late 1917 noted that a series of circumstances, including "competition with machine-made goods" and "the stringency of the recent [U.S.] immigration laws," meant that the peddlers were "dwindling in number year after year." ${ }^{\text {"55 }}$ By this time, some of the men had already begun to shift their business activities, 
following Joseph Abdin and Sofur Ally's lead, to sell clothing and other "East India Fancy Goods" to members of downtown New Orleans' black working-class population. The peddlers who made this transition were largely members of the Hooghly network who had married local women, put down roots in the city, and established supply lines of cloth goods from their associates and kin in India. In the 1920s and 1930s, these men took part in another shift in the city's racial landscape, moving into the area around Tremé's North Claiborne Avenue as it became the new heart of black New Orleans.

From the time the earliest members of the Hooghly network arrived in New Orleans, a small number had married or cohabited with local women of color. Alef Ally, for example, was already living with a young Creole woman of color, Emily "Minnie" Lecompte, by about $1891 .{ }^{56} \mathrm{~A}$ number of other peddlers followed suit: Jainal Abdeen married Florence Perez in 1893; Moksad Ali married Ella Blackman in 1895; Abdul Hamid married Adele Fortineau, and Sofur Ally married America Santa Cruz in 1900; Joseph Abdin married Viola Lewis in 1906; Hassan Abdul married Viola Wilson in $1914 .{ }^{57}$ The overall number of these marriages was small-fewer than two dozen were recorded between the 1890 ond the 1910 - - but they were clearly crucial to the Hooghly operation. While the boardinghouses and group households provided spaces of mentorship, companionship, and coordination for the large numbers of transient men who were moving through the network, the marriages-or more specifically, the women whom Bengali peddlers married-appear to have facilitated the network's integration into local neighborhoods, communities, and economies. A few of these women, such as Ella Blackman and Viola Lewis, were from the areas of African American in-migration that had developed on the uptown side of New Orleans in the decades following Emancipation. Others-such as Emily Lecompte, Florence Perez, and Adele Fortineau-were from Creole of Color families on the downtown side of New Orleans. None of these women were well-off, and most were in their teens when they married the Bengalis. All but one, however, were born and grew up in New Orleans. In some cases, the women had deep generational roots in the city, and in Tremé in particular. They had local knowledge, local networks, and a local cultural fluency far beyond those of their immigrant husbands. ${ }^{58}$ 
As they brought this knowledge and fluency to their partnerships, New Orleans women of African descent came to be connected across oceans to women in West Bengal. ${ }^{59}$ The peddlers' impressive mobilitytheir capacity to move goods and money back and forth across thousands of miles-depended upon the presence and the work of women at every node in their network, from Hooghly villages to southern U.S. cities. The division of labor between "male migration and female domestic labor," was a defining feature of sojourning networks of this era. ${ }^{60}$ While men traveled to find work overseas, the women who remained in their villages performed the crucial role of keeping up homes, land, and livestock. In Southern Italy, for example, women "took over all household responsibilities," while growing food and engaging in small handicraft production and wage work. When Italian women began emigrating to the United States in greater numbers, they took on similar roles in New York, New Jersey, Philadelphia, and elsewhere. Their domestic and reproductive labor, homework, and garment factory work provided their households with stability while men engaged in manual labor that was inconsistent and poorly paid. Women's work, in the household and in factories, was also the precondition for Italian immigrant men to open and operate small businesses. ${ }^{61}$

The network of Bengali Muslim peddlers that took hold in New Orleans and other parts of the South was similar; most of the chikondars were sojourners who maintained their ties to families and villages on the subcontinent and eventually returned, relying on others to maintain their land holdings in the interim. ${ }^{62}$ But as much as the Hooghly peddler network relied upon the work of Indian women in home villages, it functioned in North America because of the labor of U.S. women of color. Women in Babnan and Chandanpur produced embroidered goods and maintained the Indian side of split families and households. African American women anchored the network's operations in New Orleans and elsewhere in the South. They worked in the boardinghouses that Indian men established, in at least one case living as the only woman among large groups of sojourning men, apparently cleaning, cooking, and laundering. Widowed women of color took in peddlers as boarders in the spare rooms of their apartments where they likely also looked after their domestic needs. The women who married Bengali peddlers kept up their 
households in the United States even as the men continued to travel through the network, raised their children, and would have connected the peddlers to their own circles of family, friends, and acquaintances; they provided their partners with the intellectual and domestic labor that enabled them to establish and run businesses and allowed hundreds of other, more transient, members of the network to work in New Orleans and to pass through on their way to other locations further east, west and south.

Were these simply marriages of convenience? Archival records suggest no clear answer. The relationships between Bengali men and local

Table 3. Indian Mixed Marriages, New Orleans, 1890-1920

\begin{tabular}{|c|c|c|c|c|c|}
\hline Year & Groom & Age & & Bride & Age \\
\hline c1891 & Alef Ally & & $\mathrm{m}$. & Emily Lecompte (CR) & \\
\hline 1892 & Moksad Ali & 27 & $\mathrm{~m}$. & Ada Wallace (AA) & 17 \\
\hline 1893 & Jainal Abdeen & 26 & $\mathrm{~m}$. & Florence Perez (CR) & 20 \\
\hline 1895 & Moksad Ali & 29 & $\mathrm{~m}$. & Ella Elizabeth Blackman (AA) & 24 \\
\hline 1896 & Shaik Aynnaddeen Mondol & & $\mathrm{m}$. & Rita Albrier (CR) & \\
\hline 1897 & Asa Alli & 40 & $\mathrm{~m}$. & Aurelia Urbain (CR) & 18 \\
\hline 1900 & Abdul Hamed & 25 & $\mathrm{~m}$. & Adele Fortineau (CR) & 19 \\
\hline 1900 & Sofur Ally & 28 & $\mathrm{~m}$. & America Santa Cruz (CUB/CR) & 16 \\
\hline 1901 & Shaik M. Alley & & $\mathrm{m}$. & Corinne Villar (CR) & \\
\hline 1905 & Bahador Ali Molar & 38 & $\mathrm{~m}$. & Florence Gertrude Wilbert (AA) & 22 \\
\hline 1906 & Joseph Abdin & 45 & $\mathrm{~m}$. & Viola Ida Lewis (AA) & 22 \\
\hline 1909 & John A. Martin (AA) & 22 & $\mathrm{~m}$. & Nofossu Abdeen* & 18 \\
\hline 1909 & Victor Dupart (CR) & 21 & $\mathrm{~m}$. & Sadie Ally* & 18 \\
\hline 1910 & Ensan Ally & 35 & $\mathrm{~m}$. & Camille Basset (CR) & 18 \\
\hline 1911 & Abdul Rub & 21 & $\mathrm{~m}$. & Olga Santa Cruz (CUB/CR) & 18 \\
\hline 1911 & Maxest Ally & 31 & $\mathrm{~m}$. & Ananise Sylvester (CR) & 16 \\
\hline 1911 & Denis Schaff & 22 & $\mathrm{~m}$. & Viola Alley* & 20 \\
\hline 1914 & Hassin Abdul & 28 & $\mathrm{~m}$. & Viola Wilson (AA) & 21 \\
\hline 1914 & Frank Carey Osborn (AA) & 32 & $\mathrm{~m}$. & Nofossu Ella Abdeen* & 20 \\
\hline 1916 & Nazaf Alli & 31 & $\mathrm{~m}$. & Juanita Marita Lambert (AA) & 24 \\
\hline 1917 & Abdul Hamid & 21 & $\mathrm{~m}$. & Emma Fortineau $(\mathrm{CR})$ & 19 \\
\hline 1918 & Hassan Abdul & 32 & $\mathrm{~m}$. & Leonora Pavageau (AA) & 24 \\
\hline 1919 & Joseph Anthony Jensen (AA) & 23 & $\mathrm{~m}$. & Hazel Adele Alley* & 18 \\
\hline 1920 & Abdul Jalil & 25 & $\mathrm{~m}$. & Jeanne & 18 \\
\hline 1928 & Monibur Rohfman & 38 & $\mathrm{~m}$. & Lillian & 23 \\
\hline
\end{tabular}

Abbreviations in parentheses indicate the best determination of each spouse's racial/ethnic ancestry. (CR) refers to Creoles of Color; (AA) refers to African Americans with roots outside of New Orleans; (CUB/CR) is used for the Santa Cruz sisters, who were of Cuban and Creole descent.

Source: City of New Orleans, Bureau of Health, Certificates of Marriage, Louisiana State Archives, Baton Rouge.

*Child of earlier interracial family. 
women of color appear to have been varied in their nature, dynamics, and longevity. Alef Ally and Emily Lecompte never married but had two children together whom Alef continued to care for after Emily died. The evidence also suggests that Alef brought Emily and their first daughter, Mary Sadie, with him to visit India in 1896, a gesture that indicates a level of intimacy beyond mere convenience. Some marriages, however, were very short-lived. Moksad Ali's first marriage, to Ada Wallace, lasted less than three years; Aynuddin Mondul's marriage to Rita Albrier lasted less than four. In 1920, ten years after her marriage to Ensan Ally, Camille Bassett Ally was living with her mother, and Ensan was nowhere to be found. Ensan Ally's case was probably closer to the norm than Alef Ally's; that is, when members of the Hooghly network returned to India for extended periods of time-or for good-they left their American wives and mixed-race children behind in the United States. Nevertheless, there were other New Orleans marriages, like those of Sofur Ally and America Santa Cruz, Moksad Ali and Ella Blackman, and Abdul Hamid and Adele Fortineau, that lasted many years, until one or the other spouse passed away. ${ }^{63}$

The evidence does suggest a pattern: between 1900 and 1920, an increasing number of the Bengali peddlers' marriages were to women from Tremé, and by 1920, the majority of the Bengalis in the city had moved into the neighborhood's center (see Map 1). This shift may have occurred in a couple of different ways. The men may have begun selling their goods in the emerging commercial area along North Claiborne Avenue in the 1910 s and as a result come in contact with more women from the neighborhood. Or those men who first married and partnered with local women from Tremé may have gained greater footing in the neighborhood over time, become more rooted there, and facilitated other Bengalis' shift to selling goods there. It is likely that the two phenomena were simultaneousthat each fed into the other. There were, however, other factors leading the Bengali peddlers further into black New Orleans. In addition to the events that were making the Hooghly network's continued global operation more complicated-the world war, the new U.S. immigration regime, continued competition from machine-made textile goods-New Orleans' residential and commercial segregation was becoming more pronounced. In the same years that the Bengalis were moving further into 

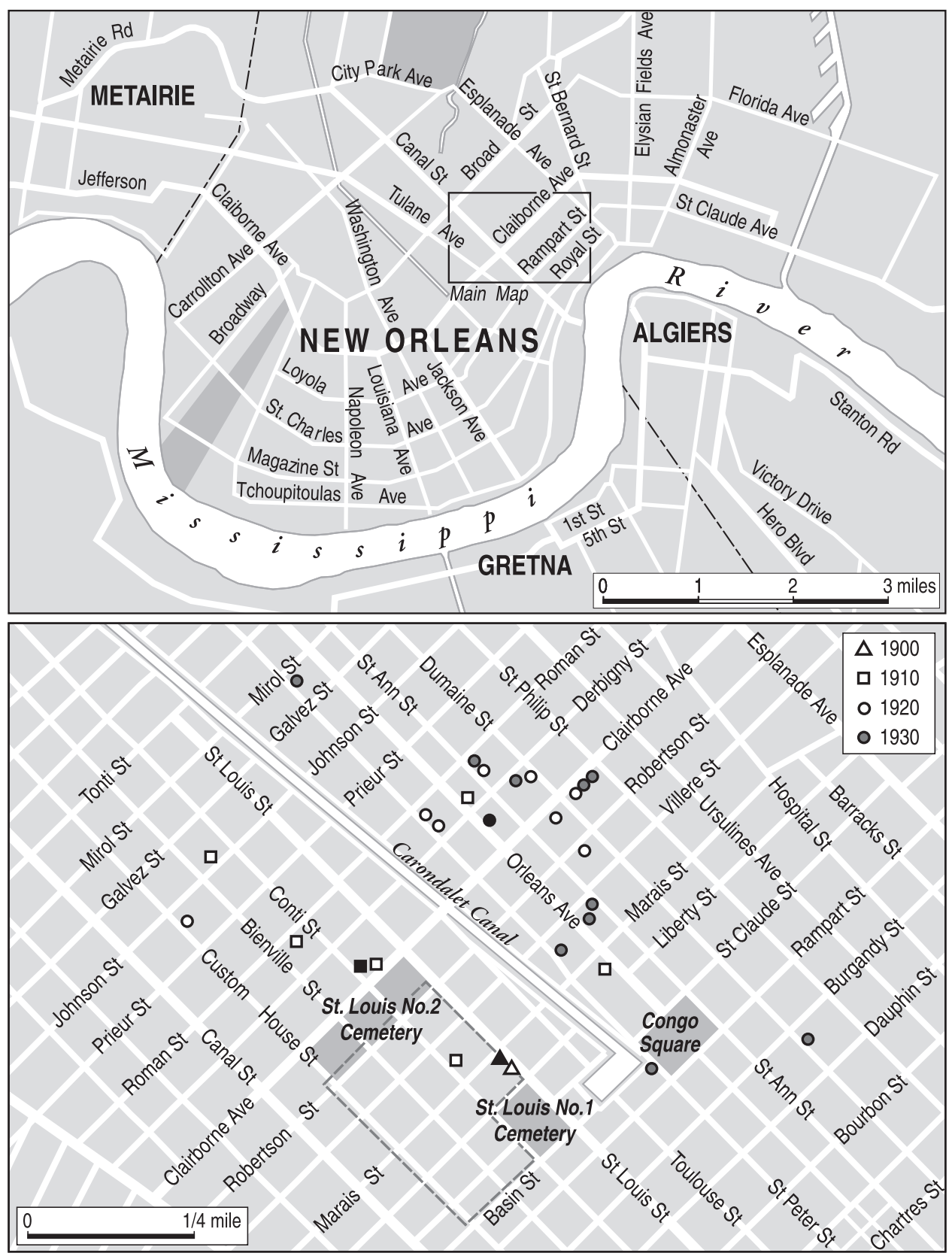

Map 1. Indian Peddler Households in New Orleans, 1900-1930. Those marked in black indicate addresses that were listed on two or more consecutive decennial censuses as homes of Indian peddlers: 1428 St. Louis Street (1900, 1910, 1920), 1711 Conti Steet (1910, 1920), and 1719 Orleans Avenue (1920, 1930). Source: USDC/BC, Population Schedules for New Orleans, LA (various, 1900-1930). 
Tremé, the European immigrants who had been part of the neighborhood for at least two generations were moving farther out, relocating to new, predominantly white areas beyond the city's core. ${ }^{64}$

Just as significantly, New Orleans' shopping districts became racially segregated. Canal Street, the centerpiece of the city's modern new image, was increasingly off-limits to black New Orleanians as customers, workers, merchants, or businesspeople. As early as 1913, writes geographer Michael Crutcher, "[an] advertisement for the Success Restaurant and Confections, located at 1428 Canal, boasted that the establishment was 'The Only Restaurant on Canal Street for the Accommodation of Colored People'... [and] African Americans were prohibited from working in visible positions alongside whites." The result was the growth of commercial and business districts elsewhere that catered specifically to African Americans; one such district formed in uptown, along South Rampart and Dryades Streets, and another, much larger one formed in Tremé along North Claiborne Avenue. ${ }^{65}$

Crutcher's description of the North Claiborne district sheds light on the role that members of the Hooghly network came to play in the Tremé community. The area, he argues, first formed around three key forms of black independent business: "insurance companies, funeral homes, and pharmacies." All of these were rooted in the nineteenth-century medical, benevolent, and burial societies that downtown's poor and workingclass communities of color developed for pooling resources to cover the costs of illnesses and deaths. In the early twentieth century, black funeral homes, pharmacies, and insurance companies came to play the roles that neighborhood associations had once done, offering services in which members of the community could pay small amounts over time to ensure that they could afford future medical and burial expenses. The growth of these businesses was also tied to New Orleans' segregation; according to Crutcher, white undertakers found it too expensive to maintain separate facilities for black customers and were willing to give up their black business, while white insurance companies were simply so arrogant and abusive toward their black customers that local blackowned companies successfully competed for and took over their business. Collectively, these three types of black enterprise became the anchor for the new commercial district on North Claiborne Avenue. New Orleans' Bengali peddlers found their own niche on North Claiborne 
setting up businesses that followed the same logic as that of these enterprises. ${ }^{66}$ As their tourist-based trade in chikan embroidery began to wane and kin and co-villagers returned to India, a group of Bengali peddlers remained in Tremé, opened shops, and sold a mix of Indian embroidered and "fancy" goods and American ready-made clothessuits, dresses, and women's silk undergarments—on installment to local black customers. ${ }^{67}$

These men were at the very heart of the Claiborne Avenue district in the 1920 and 1930s, where, in Crutcher's words, businesses "catered to the community's specific needs for food, clothing, and entertainment." Sofur Ally's "dry goods shop" was located just off the main strip of North Claiborne on St. Peter Street. Abdul Rahman ran a "ladies dress store" at 826 North Claiborne Avenue in the center of the district, where he employed three other former members of the Hooghly network as salesmen. On the 900 block of North Claiborne, Towakkal Haldar and Abdul Jalil, both former itinerant peddlers, operated a "ready-to-wear store," at number 914, and Abdul Rohim Surker, a younger member of the Hooghly network who had been living as one of Alef Ally's boarders in 1910, opened another shop selling women's dresses and "East India fancy needlework," at 928 North Claiborne. Abdul Hamid had a silk store nearby and later operated a soft-drink stand. These businesses were in the liveliest part of Claiborne Avenue's black commercial district. Abdul Rahman's shop was two doors down from one of Tremé's most important black-owned businesses, the Lebranche Pharmacy. Rahman's, Haldar's, and Hamid's shops were also all just half a block on either side of the corner of North Claiborne and Dumaine, a location that jazz musician Danny Barker described as "one of the most famous corners in New Orleans" in this period. The corner, which was home to "the Chattard Brothers' barber shop and Big Al Dennis' shoe shine stand," was a site where local men would gather to gossip and talk about boxing. "Around the corner on Dumaine," Barker remembered, "was Joe Sheep's ... [which] had the best hot sausage sandwiches in town," and down the middle of North Claiborne was the shady "neutral ground," a strip of green space where neighborhood kids played and black "Mardi Gras clubs paraded." Sidney Bechet also remembered this stretch of North Claiborne Avenue as the main "meeting place" when local bands and clubs were parading: 
"the people they'd be up by Claiborne Avenue and St. Philip. They knew you'd be coming there. You had to pass some time." The Bengalis were not the only Asian immigrants here. Next to the Chattards' barber shop, on Dumaine, was a Chinese laundry, and the Chattards employed a young man who was "half-Chinese, half-black," possibly the son of the laundry's proprietor. ${ }^{68}$

Because of their location and the business they conducted, the Bengalis would have become a well-known part of Tremé in this era. The nature of their layaway business would have meant that they developed long-term relationships with their customers, which would have likely required a sense of mutual trust. Unlike many other immigrant businesspeople operating in African American areas in this era, the men lived in the neighborhood where they sold their goods. As the U.S. operations of the Hooghly network eventually came to an end, these men remained anchored in Tremé, became woven into the fabric of the neighborhood: through their marriages to local women and relations with their families, through a web of relationships with customers, and ultimately through their children. Alef Ally had his two daughters; Moksad and Ella Ali had one daughter and six sons; Joseph and Viola Abdin had two children; Jainal and Florence Abdeen had four; Abdul and Adele Hamid had one; and Sofur and America Santa Cruz Ally had nine. While the fathers had been part of a network that stretched back to Calcutta and Hooghly, Bengal, their children were of black New Orleans. ${ }^{69}$

\section{Traces of Lives}

The stories of Sofur Ally, Jainal Abdeen, and Moksad Ali-three of the first Bengali peddlers to settle in New Orleans-provide a glimpse of the different trajectories that mixed families took over the early years of the twentieth century. Sofur Ally arrived in New Orleans in 1895. He had traveled from Calcutta to New York with twenty other peddlers that year, heading for the New Jersey beach resorts at the beginning of the summer. By the time of the 1900 U.S. Census, he was living in the joint household at 1420 St. Louis Street with Solomon Mondul, Eshrack Ali, Abdul Subham, and others on the edge of Storyville. Later 
that year, Sofur married America Santa Cruz, a Louisiana-born woman whose father was Afro-Cuban and mother was of local Creole and Cuban descent. By 1910, the couple had had three children, Abraham, Isaac, and Mohammed, and moved to a house at 1806 Orleans Avenue on a residential block not far from North Claiborne Avenue. Here, Sofur was listed as a "street peddler." Ten years later, the 1920 census found Sofur and America living on St. Peter Street on the northern edge of Tremé. They now had six children, including the youngest three, Abdul, Belle, and Fatima. Sofur Ally had naturalized and was listed as the proprietor of a dry-goods store. The Ally's eldest son, Abraham, now eighteen, was working as a delivery boy for his father.

By 1930, at the height of the Depression, Sofur and America Ally were living on St. Ann Street, back around the corner from where they had lived in 1910, just off Tremé's commercial thoroughfare. They had three more children, Hassan, Corinna, and Alema. In what is perhaps a sign of the family's financial struggles, the U.S. Census no longer listed Sofur as the proprietor of a shop; he had gone back to street peddling, and now three of Sofur and America's New Orleans-born, BengaliCreole sons had joined their father and other remaining members of the Hooghly network in the trade: Abraham, twenty-eight, and Abdul, eighteen, were listed as peddlers of "retail perfumes," and Mohammed, twenty, as a peddler of "retail merchandise." Apparently pooling their resources with the family, these three adult sons lived with their parents and most of their siblings in a household of nine. ${ }^{70}$

Sofur Ally had at this point lived in New Orleans for thirty-five years and had been married to America for thirty. Over that time, he became increasingly rooted in his wife's native city and began to play a middleman role for other Indians. While Sofur Ally was one of the first Bengali peddlers to move into the commercial and cultural heart of Tremé, members of America's family had lived there for at least two generations. Sofur and America's home at 1806 Orleans Avenue became a destination for other peddlers from the Hooghly network making their way to New Orleans, including Fortik Sheik and Taslimuddin Mondul, who traveled from Calcutta in October 1908. According to his descendants, Sofur worked with local city officials and leaders in Tremé's predominantly black Catholic Church parish to build bridges between 
the men from Bengal and the local community and founded a "welcome center" for men arriving from the subcontinent, helping them adapt to New Orleans and likely taking them in for extended periods of time. After going through the process of opening a business, he helped other Bengalis with official paperwork, signing as a witness, for example, on the passport application of another Indian peddler, Roston Ally, in 1918. As for America, over the course of three federal censuses, she was consistently listed with the word "none" written in the "occupation" column-a notation that obscures the role that she played in easing Sofur Ally's own transition to New Orleans and providing a bridge between Sofur and other members of her family and community. It also belies the decades of domestic and reproductive labor she provided to sustain the Ally household as a family, as a functioning economic unit, and as place of residence and space of welcome for other men from the subcontinent. One descendant of Sofur and America Ally understatedly describes the couples' sons-Abraham, Isaac, Mohammed, and Abdul—as men who "expected a lot from their women," a trait they clearly learned from their father. ${ }^{71}$

The trajectory of Jainal Abdeen and his family demonstrates how uncertain life was for the working-class communities of color within which Indian Muslim migrants settled in turn-of-the-century New Orleans. Jainal came to the city around 1888 . In the early years, he appears to have played some of the roles that Sofur Ally later came to play within what was then a quite small population of Bengalis in New Orleans. In the absence of an imam, Jainal performed the wedding rites when his friend Moksad Ali married Ada Wallace in 1892, being forever recorded on their wedding certificate as "Reverend" Jainal Abdeen. The next year, five years after his own arrival in New Orleans, Abdeen married Florence Perez, a local Creole woman. The 1900 U.S. Census, compiled in June, showed that Jainal and Florence Abdeen were living about two and a half miles northwest of Storyville, in a racially mixed working-class residential area of New Orleans' Third Ward. They had four children, Arthur, nine, Nofossur, six, Kahdidje, three, and Jainal Jr., seven months. Despite this listing in the census, however, records show that Jainal Abdeen Sr. had in fact died from tuberculosis six months earlier, in January of that year. His appearance in the census record suggests that Florence 
Abdeen may have hidden his death from the census enumerator and from her landlord, a likely scenario if she feared being evicted and put out on the street with her four children. The Abdeens were absent from the next census, in 1910, when they were perhaps without a fixed address, and then in 1912, Jainal and Florence's daughter, Kahdidje, died at the age of fifteen from smallpox. Marriage records show that Kahdidje's sister, Nofossur, had married a man named John Martin in June 1909, when she would have just turned sixteen years old. This marriage did not last; in 1914 , at the age of twenty, she was married a second time, to thirty-twoyear-old Frank Osborn, an African American man who had come to New Orleans from Alabama. ${ }^{72}$

Frank and Nofossur were the only members of the extended Abdeen family to appear in the 1920 U.S. Census. At this time, their household seemed to have regained some footing: the young couple were living in a mixed working-class area of the Third Ward with their four children, whose ages ranged from eight months to seven years, as well as with a sisterin-law, an uncle, and a cousin from Frank's side of the family. There were three wage earners in the household, all part of the large black workforce on New Orleans' waterfront: Frank was working as a longshoreman, his uncle as a cotton "weigher," and his cousin as a dock laborer. ${ }^{73}$ Four months after the census was enumerated, however, whatever stability this extended family had achieved began to unravel. In April of 1920, Nofossur died at the age of twenty-six, and four years later, her husband, Frank, died at the age of forty-three, leaving their four young children orphaned. By 1930, the only traceable members of this family line, begun by Jainal Abdeen and Florence Perez in 1893, were two of their orphaned grandchildren: Florence Osborn, now a fourteen-year-old girl and the adopted daughter of a sixty-eight-year-old Creole of Color woman, Wicker Aguerila, and Raymond Osborn, listed as an eleven-year-old boarder in a household consisting of a seventy-six-year-old street peddler, a fifty-two-year-old laundress, and a fifty-one-year-old ship's carpenter, on the edge of the former Storyville district. ${ }^{74}$

Moksad Ali settled in New Orleans around the same time as Jainal Abdeen and married a local African American woman, Ella Blackman. Ella's family had come to New Orleans from other parts of the South in the years before and after the Civil War. Her father's side came from 
Tennessee, her mother's from Virginia. Moksad and Ella married in May 1895, when Ella was seven months pregnant with their first child, Monzure. On Monzure's July 12 birth certificate, Moksad Ali listed his occupation as "silk merchant" and penned a clear but labored signature in Roman/English cursive letters. Five years later, the 1900 U.S. Census recorded that Ella could read and write English but Moksad could only speak the language. At this time, Moksad and Ella were living in New Orleans' Third Ward as heads of a large, mixed, extended family. Their household included their first three children, Monzure, Karamouth, and Roheamon, Ella's younger sister Fanny, Fanny's husband, John Brooks - who was from Georgia, and was of Haitian and Jamaican descent-and Fannie and Ella's eighty-year-old grandmother, Hannah Judah. Judah was a freed slave from Virginia who had come to New Orleans in the 1840s and had supported Ella, Fanny, and their mother in earlier years, working as a housekeeper. It was a diverse family, spanning four generations with roots in multiple southern states, the Caribbean, and the Indian subcontinent, as well as in at least two religious traditions, and in experiences of both colonialism and slavery. Blurring these multiple histories, the census taker recorded everyone in the household as "Black" and did the same for the majority of residents on the same block, with the exception of Moksad and Ella's next-door neighbors, an Italian immigrant family with five Louisiana-born children. The adults in the immediate surroundings of the Ali-Judah-Brooks household worked different jobs on the lower rungs of the city's economy: Moksad Ali was a peddler of silks, his neighbor Antonio Borasso was also a peddler, of vegetables, his brother-in-law John was a day laborer, and among their African American neighbors were three cooks, two seamstresses, a midwife, a butcher, and four other day laborers. ${ }^{75}$

Moksad and Ella Ali's was one of several East Indian-African American families from New Orleans that took part in the Great Migration. These included Nazaf and Juanita Lambert Ali, who married in New Orleans in 1916 and migrated to Chicago around 1918, where Nazaf worked alongside the thousands of African American men from southern states in the city's stockyards. It also included John and Jennie Abdullah and Charles and Albertine Barber, married in New Orleans in 1911 and 1912, respectively, who were all living together in Los Angeles in 1920. Here, 
the two men-Indians who had changed their names after settling in the United States-found work that would have been familiar to Indian seamen of this era, firing the furnaces of "stationery engines," probably in a factory or railroad setting. ${ }^{76}$

In the case of Moksad Ali, he, his wife Ella, and their three children moved from New Orleans across the Mississippi River delta to nearby Hancock County, Mississippi, sometime around 1903. Here, Moksad and Ella had four more sons, Rostom, Abdeen, Bahadour, and Arfin. The 1910 U.S. Census recorded the Alis as a family of seven living in a predominantly black area of rural Mississippi, near the town of Waveland, and listed Moksad, a "merchant," as the only wage earner. Although Moksad and Ella had eight children over the course of fifteen years, there are indications that Moksad kept circulating through the peddler network over this period, leaving Ella on her own with their children for extended periods of time. In 1918, when Moksad Ali was afflicted with tuberculosis, he died not in Mississippi with Ella and his children, but at the boardinghouse at 1428 St. Louis Street in New Orleans. Sometime either just before or soon after Moksad Ali's death, Ella joined the northward flow of the Great Migration, bringing six of her children to New York City to move in with her sister Fannie in the Bronx. ${ }^{77}$

By the time they had reached their teens and early twenties, Moksad and Ella Ali's children Roheamon, Rostom, Abdeen, and Bahadour were all living at the edge of Harlem, and it was not long before all three moved the short distance across the Harlem River into a neighborhood beginning to crackle with possibility for people of color from all over the country and all over the world. Bahadour moved right into the center of Harlem's growing black community, to an apartment on West 133rd Street between Seventh and Lenox Avenues, and married a young woman who had also come from the South, twenty-four-year-old Margaret Carree, from Savannah, Georgia. On their marriage certificate, Bahadour gave his age as twenty-three and his occupation as "actor," and both Margaret and Bahadour were officially classified as "colored." Rostom moved just two blocks away to an apartment on 135th Street and married seventeen-year-old New York-born Pearl Pierce. Their 1924 marriage certificate also records husband and wife as "colored" and shows that Rostom had found a far less glamorous occupation 
than his younger brother; Rostom was working as a "fireman," which in this case most likely referred to the job of shoveling coal and stoking furnaces in the basement boiler rooms of hotels and other large buildings. Around this same time, sister Roheamon married Arthur Straker, a former boarder in their family's Bronx apartment. In 1930, the two were living on St. Nicholas Avenue between 151st and 152nd Streets. Their occupations were recorded as "housewife" and "laborer," respectively, and both were racially classified as "negro." Younger brother Bahadour was now living with them, along with a second wife, Thelma, a twentysix-year-old African American actress from Texas. ${ }^{78}$

Bahadour's classification as an "actor" turned out to be an understatement; Moksad and Ella's fourth son would go on to have a long career in black show business. Sometime in the 1920s, Bahadour changed his name to Bardu. He began performing as a dancer on the era's black vaudeville circuit, partnering with a young woman, possibly his wife, Thelma, as the team "Baby and Bardu Ali" and with his younger brother, Abdeen, as "The Ali Brothers." In 1926, young Bardu came to the notice of the Baltimore Afro-American, which profiled him on their theatrical page, describing him as the son of a "Turkish" father and "Creole" motherneither of which was quite true: "Ali is the son of Makrad [sic] Ali, a Turkish silk importer who came to America many years ago and engaged in the silk importing trade in New Orleans. The father married the now Elizabeth Ali, a Creole girl of that city and from the union have been born nine children, Abdeen, Bahadour, Mohammed, Aklemia, Roheanon $[s i c]$, Monseur [sic], and others with names just as unusual among the colored populace." Although the Afro-American set the Ali siblings apart in this way from "the colored populace," it simultaneously claimed them, reporting that Bardu was "proud of his Negro ancestry" and that his brothers "seem quite capable of taking care of themselves, they were raised in New York City and 'know their stuff' as the current parlance of the day expresses it." ${ }^{979}$

Bardu quickly made a name for himself in black theatrical and music circles as a suave and crowd-pleasing emcee and in the 1930 s was recruited by one of Harlem's leading swing jazz bandleaders, Chick Webb. In this role, Bardu Ali is often credited with introducing Webb to a young Ella Fitzgerald and insisting he hire her as a singer for the Chick 
Webb Orchestra, an event that launched her own long career. After Webb's death, Bardu Ali moved to Los Angeles, where he became an instrumental part of the city's Central Avenue music scene in the 1940s. Here he teamed up with the drummer Johnny Otis to open the Barrelhouse, the country's first nightclub devoted to the emerging style of rhythm and blues. Ali closed out his career in the 1970 s as the business manager for the comedian Redd Foxx, at the time that Foxx was acting in his own situation comedy, Sanford and Son. By the time he died in 1982, Bardu Ali, one of the first children born of the migration of Bengali peddlers to New Orleans, had been involved in multiple phases in the development of twentieth-century black entertainment, from $1920 \mathrm{~s}$ vaudeville to swing-era jazz, to rhythm and blues, to one of the first African American sitcoms on prime-time U.S. television. ${ }^{80}$

\section{Embedded, Enmeshed}

The lives of Bengali Muslim peddlers and their descendants became embedded within black communities and entwined with their histories. Over the decades that men from West Bengal lived, worked, and established roots in New Orleans, migrants from the subcontinent were barred from entering the United States as immigrants, from owning property, and from becoming citizens. ${ }^{81}$ Over the same period, a broadly heterogeneous New Orleans was divided by both the laws and practices of Jim Crow into unequal "White" and "Negro" worlds. Although their livelihood still likely depended on crossing back and forth between these two worlds, "Negro" New Orleans provided a home for the handful of Bengali traders who chose to settle permanently in the United States and an anchor for the scores of others who continued to travel through the global and regional circuits of the Hooghly network to ply their trade. As a result, these Muslim migrants from colonized India made their lives with and among black southerners who had survived slavery or were the children of slaves, with members and descendants of a Creole community that was engaged in mounting legal and political challenges to Jim Crow, and with immigrants and children of immigrants who had escaped political upheavals in the Caribbean. 
African American women were also deeply embedded in the structure of what might, at first glance, seem to be simply a Bengali peddler network. Because neither they nor the women who labored in Hooghly villages moved through its circuits, however, these women had a different experience of the chikondar network. The men were globally mobile. They encountered and interacted with multiple different people in varied spaces. They traveled together and built new connections to people in the places they worked. The lives of the women on either end of the network depended much more on their local circumstances; in the absence or loss of their own local support systems, the women's experience of this dynamic global network could be one of hardship and isolation. The women likely never met their counterparts on the other sides of the ocean; the two groups likely knew little of one another. But they shared the experience of being alone in the absence of their peddler husbands, just as they shared some of the network's greatest risks. These risks are brought home in the stories of two women-Jennat Bibi and Minnie Wade Mollah-captured in fragments of archival evidence from the 1910 s and 1920 .

Jennat Bibi made her way into the archives in 1918 when she sent a letter to her husband, Roston Ally, urging him to return from New Jersey to his home village in Bengal. Roston Ally was one of the earliest members of the Hooghly network to come to the United States. By the time of Jennat Bibi's letter, he had naturalized and had been moving back and forth between Atlantic City and New Orleans, peddling goods, for twenty-three years. Roston submitted Jennat Bibi's letter to U.S. authorities as part of an application for a passport to return to India, stating that his wife had asked him to return to "settle his affairs." Roston Ally may have included Jennat Bibi's letter simply as part of a strategy to strengthen his case for traveling papers-conveying to U.S. authorities that he had a wife on the subcontinent who needed him to "come home" to address pressing family matters. In fact, other records indicate that Roston Ally had married and had a child with another woman in New Orleans after coming to the United States.

When Roston Ally arrived in the United States in June 1895 as part of a group of twenty Bengali peddlers on their way to Long Branch, New Jersey, it is likely that he had only recently been married to Jennat Bibi. 
Records indicate that he had made only one trip back to India since that time, in 1905, after successfully gaining U.S. citizenship. Now, more than a decade after this visit, Jennat Bibi spoke of the growing difficulties she was experiencing, trying to fulfill her role looking after property that belonged to a husband she had barely known. For his part, Roston Ally had clearly abdicated his own role in maintaining a family economic unit across oceans and national borders. "It is two years since my health is broken," Jennat Bibi wrote. "My mother and father have both died. I have no relatives with whom to live. Unless you come, all of your lands and property will be taken away. ... [Y] our cousin never gives me anything of the produce of your lands.... [Y] ou must come home immediately. And after you come home, we both could go to America to live, after selling all the lands and property."

Jennat Bibi's letter suggests the tenuousness of the Hooghly network in terms of its ability to provide a secure life for the women on the Indian end of the circuit. At the same time, it points to the importance of the role these women played, maintaining a place for their husbands in their home villages while they were away for extended periods of time. There are different ways of reading her letter. It is possible that all of Jennat Bibi's support networks had indeed broken down in Roston Ally's absence, leaving her vulnerable to the machinations of his other male relatives. It is also possible that Jennat Bibi had come to fear that Roston Ally would never return (perhaps hearing from others in the extended kinship network that he had married another woman in the United States) and was using the potential loss of his property as an oppurtunity to get him to come back to his village. In either case, it was Jennat Bibi's inability to hold on to the land that was central to her plea for Roston Ally's return. She appears to have known that the land would most likely motivate him to travel back to India even after living in the United States for more than two decades. Tellingly, Roston Ally did travel to India soon after being granted a passport and, after presumably seeing to his land, returned to the United States in 1923 on his own, again leaving Jennat Bibi behind. ${ }^{83}$

Minnie Mollah, the wife of Bengali peddler Abdul Rub Mollah, was in French Lick, Indiana, far at the other end of the network. Minnie was the daughter of former slaves. Her father, recorded in the 1880 U.S. 
Census as "Capt. Wade," was born in Tennessee in 1847. Her mother, Alice Wade, had been born into slavery in Mississippi in 1855 and had gained her freedom along with her mother and a younger sister at the end of the Civil War. By the time Minnie was born, in 1879, her parents were living in St. Louis, Missouri, where her father was working on one of the regional railroads. Minnie did not marry early, like many young women of her era did, but instead became a public schoolteacher in St. Louis and continued to live with her mother and a stepfather into her early thirties. Around 1915, when she was thirty-six years old, Minnie married Abdul Rub Mollah, a peddler ten years younger than she who had come to the United States in 1909. Mollah had first worked in New Orleans, where he lived in a group household at 320 North Roman Street with Fazleh Rahman, Taslimuddin Mondul, and other senior members of the Hooghly network, and then made his way to St. Louis, where two other members of the network had begun peddling goods around $1910 .{ }^{84}$

It is unclear where and how they met, but soon after Minnie and Abdul Rub Mollah were married, the couple moved to French Lick, a predominantly white rural town two hundred miles due east of St. Louis. French Lick was a regional tourist destination; it was home to one of the Midwest's premiere health resorts, centered around the town's natural springs and springwater. Here, on Maple Street, the small town's main commercial thoroughfare, Abdul Rub Mollah opened an "Oriental Gift Shop" next to a clothing store and the offices of the local electric company. He also filed a Declaration of Intention to naturalize soon after his marriage to Minnie, and in 1918 he was granted U.S. citizenship in the Circuit Court of Orange County, Indiana. Almost immediately afterward, Mollah applied for a U.S. passport, and in 1919, he left Minnie in French Lick to tend the shop while he went back to India for two years. Although he returned to Indiana in 1921, Abdul Rub took at least two more two-year trips to India over the next fifteen years, presumably to send and bring back stock to sell in Mollah's Oriental Gift Shop, which Minnie was left to run in his absence. ${ }^{85}$

This arrangement would have been quite different from leaving Minnie to run a business in her hometown of St. Louis, where she had family and where there was a large African American community. Although 
French Lick had a historical connection to the Underground Railroad, by the time Minnie and Abdul moved to the town, its black community consisted of a small number of service workers employed at the French Lick Springs resort hotel. This was not friendly territory for Minnie. Not only had the nineteenth-century founder of French Lick Springs been a Confederate sympathizer who had organized a white secret society to stop abolitionists' activities in his town, but by the 1920 s and 1930s, the state of Indiana itself was home to the largest branch of the Ku Klux Klan outside the South. In this era, up to 30 percent of Indiana's adult white male population were in the Klan, and the organization's members were deeply integrated in local and state government.

Even in such a context, Minnie successfully ran Mollah's Oriental Gift Shop for more than twenty years, both with and without Abdul's help. It is now impossible to know what kind of community she built for herself in French Lick, and how she coped in potentially hostile surroundings. The 1920 U.S. Census, conducted when Abdul Rub Mollah was in India, provides one curious piece of information. Minnie Mollah appears to have been written into French Lick's enumeration by a local census taker, without being directly interviewed. The census taker recorded her place of birth as "India," her mother tongue as "Unknown," and her race as "White," presumably because she was assumed to be Indian. As the proprietor of the town's Oriental Gift Shop, Minnie Mollah appears to have been either unintentionally or intentionally passing as Indian. ${ }^{86}$

The lives of these women-Jennat Bibi in West Bengal and Minnie Wade Mollah in French Lick-were deeply entwined with the trade in Oriental goods that had been established when men from Hooghly and Calcutta began making trips to Atlantic City and New Orleans in the 1880 os. Their labor contributed to one of the earliest manifestations on U.S. soil of what we would now refer to as the South Asian diaspora. The same can be said for numerous other women in Louisiana, South Carolina, New Jersey, and elsewhere: America Ally, Ella Ali, Celestine Gardner, Florence Abdeen, Adele Hamid, Aurelia Mondul, Olga Abdul, Anaise Ally, Juanita Alli, Leonora Hassan. In some cases these women were involved with Bengali peddlers for short periods of time, and in some cases for most of their adult lives. The work in which they 
engaged, however, provided rootedness to a trade network that stretched from villages in Hooghly through Calcutta, New Jersey, and the neighborhood of Tremé in New Orleans to multiple points in Central America and the U.S. South. The hundreds of Bengali Muslim peddlers who moved through the United States between 1885 and 1935 have remained lost to South Asian American history because these men did not immigrate and settle, did not "become American." Those few who did stay, and the descendants who remain in New Orleans and elsewhere, have been lost to South Asian American history because they integrated into black neighborhoods and communities. And the U.S. women of color who helped the Bengali peddlers put down roots, both temporary and permanent, the women with whom so many of the peddlers shared their lives, have remained doubly lost because they confound the set of ideas we employ when we construe this history simply as "South Asian." 


\section{From Ships' Holds to Factory Floors}

Recently, thirty-nine Indian workers of the Bethlehem Steel Company were arrested without warrants at the gates of the factories in Bethlehem, Pa. . . . and were taken to Ellis Island. . . . At this gate of America, they were lodged in filthy cells full of vermin. . . [T]he British Captain of the Lucerus appeared on the scene and the Hindusthanees were summarily ordered to follow him to the boat, and there [return to] work as seamen. But when they came to know it was a British ship . . . they flatly refused to obey the order. Asked the reason, they said that to work on board a British ship was worse than working in "hell."

-Basanta Kumar Roy, The Independent Hindusthan, October 1920

$\mathrm{O}$

N A Sunday morning at the end of December 1907-a time of year when Hooghly's peddlers were selling their wares far from the cold Northeast - a different set of Indian Muslim men appeared on the waters of New York Harbor. Several small groups set out in rowboats from piers all over the area-from the east-side and west-side docks of Manhattan and from the waterfronts of Brooklyn, Staten Island, and New Jersey. In the brisk winter morning air, the men rowed south and eastward across New York's crowded, choppy waterways, weaving past freighters, tramps, schooners, and ferries toward Bush Docks in South Brooklyn. There, at the edge of the neighborhood now known as Sunset Park, they climbed onto the upper deck of a German steamship, the Stolzenfels, where they prepared to mark 23 Dhul Qi'dah, the martyrdom of Ali Raza, the eighth Imam of Shi'a Islam.' These men were 
sailors, or more precisely, maritime laborers; they were stokers, firemen, coal trimmers, and stewards from various steamships that were then in port. Over the course of the day, groups of these seamen-"lascars," as the British called them-kept turning up, in one small boat after another. ${ }^{2}$ By the time of the ceremony and feast, fifty Indian Muslim men had arrived from every part of the New York waterfront and were gathered on the deck of the Stolzenfels. A crowd that included the ship's European officers, a press photographer, and a New York Times reporter stood at a distance to watch. The reporter's story appeared prominently on page 3 of the Times the next morning. His narration of the sailors' activities was a mixture of fantasy, news-speak, and condescension. "For hours before the beginning of the feast," the Times' reporter wrote:

little Lascar sailors came. . . The South Brooklyn pier at the foot of Forty-second Street was the Mecca toward which all the Lascars headed. .. . [The] little brown sailors squatted on the forward deck of the German freighter, and the sheep's head was pointed to the sun. It was then massaged by one of the Lascars until those who viewed the ceremony from the bridge felt sure that the sheep was hypnotized. Quick as a wink the animal was dispatched, and before any of the flesh was touched, every drop of blood in the animal had been allowed to trickle into a pan on the deck ... Nor was a knife used in skinning the animal. The Lascar butcher did that with his thumb so skillfully and in such a short time that a stockyard butcher could not have beaten him. While this was going on, the "band" played the sacred music incidental to the Feast of the Malah [sic]. The "music" sounded, to American ears, much like that heard at Coney Island side-shows. ${ }^{3}$

This was just one of a number of stories that appeared in U.S. newspapers at the turn of the twentieth century describing the arrival of "strange" and "curious" "Hindoo" sailors in port cities along the Atlantic and Gulf coasts. Writing from the marginal spaces of the United States' docklands and waterfronts in New York, Philadelphia, Baltimore, and Galveston, reporters ushered lascars onto the terrain of the U.S. popular imagination. 
Most of these writers fell back on familiar tropes, describing the Indian seamen in much the same way they wrote about the "Oriental" magicians and performers who had become a staple of the era's circuses and exhibitions. Some reporters chose to focus on high-seas adventures: the New York Daily Tribune reported on a live Punjab goat that ran amok on a transatlantic voyage and butted a lascar seaman overboard. The New York Times described a steamship that arrived in Philadelphia with a "choice cargo of tales from the Far East"; the ship's captain had wrestled a cobra for two hours after it slipped on deck in Calcutta, and a lascar seaman "died of fright" after meteors fell alongside the ship while it sailed through the Mediterranean Sea. Most American reporters, however, chose to focus on the incongruity of Indian Muslim seamen in local waterfront areas and attempted to describe the "queer customs" these men brought with them: daily prayer observances, dietary strictures, religious celebrations, burial practices. When two British ships carrying 125 Indian crew members docked in the port of Galveston, Texas, the Dallas Morning News launched a sensational exploration of the lascars' diet, eating habits, and religious beliefs. "One thing the Lascars will not tolerate is pork," the paper declared. "They are more afraid of pork than a woman is of a mouse. It is believed not only to contaminate the body, but also the soul, as the swine is thought to be an agent of their devil." 4

To American readers at the turn of the century, Indian seamen might as well have been fictional characters; judging by the press reports of the day, they were equal parts exotic and peculiar, inscrutable and fanatical, ridiculous and treacherous. At the same time, these articles offer us a glimpse into the lives that this population of workers from the subcontinent were fashioning for themselves as they spent days, weeks, and months in U.S. ports, waiting for their ships to unload, reload, and set back out to sea. Most poignant are the accounts of Indian seamen who were faced with burying comrades who had died during their ships' voyages. Even the most voyeuristic descriptions of these moments hint at the care the seamen took to prepare their coworkers' bodies in accordance with Muslim practice and to maintain the privacy and dignity of burial rites in unfamiliar and unsympathetic surroundings. When a Galveston newsman reported on a funeral that visiting Indian seamen held for a member of their crew, he recounted a set of deliberate steps these men 
took to guard and prepare their friend's body and ensure his proper placement in a grave facing Mecca. Another account focusing on the death of an Indian steamship cook described a "weird ceremony" at New York's Bellevue Hospital in which "each of the friends of the deceased removed his shoes and stockings and taking a pail of water, sat down on the curb outside the Morgue door and bathed his feet." Even the New York Times' 1907 account of the "Feast of the Malah," with its demeaning descriptions of "little brown men" performing like a "Coney Island sideshow," revealed that Indian seamen were organized and determined enough to secure the use of the upper deck of the Stolzenfels for their observances and then to communicate and coordinate among Muslim crew members on multiple ships spread across several miles of New York waterfront.

In the years that the U.S. operations of the Hooghly peddler network were slowing down, Indian seamen were arriving in Atlantic ports in increasing numbers. New York, Baltimore, and Philadelphia were at the edge of a maritime world that stretched far beyond the comprehension of local American newsmen. The events that had compelled and enabled Hooghly's peddlers of silks to cross oceans-the expansion of the British Empire, the opening of the Suez Canal, the arrival of steam power, and the growth and acceleration of world travel and trade-had also given rise to a new industrial workforce on the subcontinent, one that was semicaptive and hyperexploited but globally mobile. In the early decades of the twentieth century, Indians comprised almost one-quarter of the laborers on British merchant vessels. They moved through the circuits of British seaborne trade and became a regular presence in and around port cities from Asia to the Middle East to Britain and beyond. The majority of these men came from rural areas, many from smallholding farming families that were under pressure due to colonial taxation policies. In their villages and on the waterfronts of Calcutta and Bombay, there were thousands of other men like them, waiting for months or even years to find work on outgoing ships. They had to take out loans to pay middlemen in order to get hired and then, at sea, they faced indenture-like contracts and brutal conditions at the hands of British masters. ${ }^{5}$ Even in this setting, however, Indian seamen developed strategies to challenge the industry's inequities and improve their 
lives, from mutiny to black marketeering to jumping ship in ports overseas.

By the 1910 s, tens of thousands of these Indian seamen were working globally on British ships, thousands were moving into and out of the Port of New York each year, and hundreds were successfully jumping ship and disappearing into the crowded waterfronts of Manhattan, Brooklyn, and Staten Island. ${ }^{6}$ Some deserted in order to find better work and wages on other outgoing ships; others did so to find jobs in factories and restaurants onshore. They stayed in the United States for months or years at a time, maintaining clandestine networks in neighborhoods that stretched from the Tenderloin and the Lower East Side in Manhattan to Black Bottom and Paradise Valley in Detroit to the Pennsylvania Avenue district in West Baltimore. Their journey to the United States was remarkable because of the arduousness of the labor they had to perform-many shoveling coal and firing furnaces in the bellies of steamships on and off shift continuously for more than eighty hours a week - and the policing and ill treatment they faced from their British captains and officers on board. ${ }^{7}$ After 1917, those who reached the United States also faced a harsh new immigration regime, one that barred their entry into the country on explicitly racial grounds. Nevertheless, hundreds of seamen from the subcontinent were left in port or escaped British ships in search of higher wages and better lives onshore in the United States. ${ }^{8}$ As was the case with Hooghly's peddlers, they did so through a combination of ingenuity, cooperation, and coordination, building networks of their kin and countrymen onshore and at sea. Indian seamen, ex-seamen, and sympathizers passed information to one another, helped one another jump ship, and found one another work, often far from their ports of desertion across the industrial belt of the U.S. Midwest. ${ }^{9}$ They first deserted in large numbers during World War I, when there was a demand for their labor in U.S. munitions, shipbuilding, and steel factories. But once they had established their networks, Indian seamen branched out to a wide range of onshore labor, working as cooks, dishwashers, doormen, and elevator operators in New York City, silk dyers in Patterson, New Jersey, and assembly-line workers in the auto industry in Detroit. 


\section{Thirty Feet below the Sea}

The most common images of merchant seamen tend to be drawn from the seventeenth and eighteenth centuries, from the days in which ships were crafted out of wood and canvas and the crews that sailed them were a breed apart, drawn from all over the world, but more connected to the sea than to any particular place on land. In novels, comic books, and films, this world of whalers, adventurers, pirates, maroons, and mutineers has defined the popular understanding of maritime labor. In the era of sailing ships, crews were indeed often mixed; they drew members as they moved from port to port, from Liverpool to Buenos Aires to Shanghai. The division of power between a ship's officers and its crew was stark, but the crew members themselves were on a relatively even plane; while they played different roles, each sailor had to have a core set of skills, and all the members of a crew-whether European, Asian, or African in origin-had to work together to navigate difficult stretches of ocean and get through stormy seas. These crew members also shared similarly harsh conditions of labor. As historians Peter Linebaugh and Marcus Rediker have put it, the sailing ship, "provided a setting in which large numbers of workers cooperated on complex and synchronized tasks, under slavish, hierarchical discipline." Out of this context grew a seafaring underclass made up of sailors and pirates who had been brought together across differences of color, ethnicity, and language by common experiences of labor and subjection. The sailing ship "became ... a meeting place where various traditions were jammed together in a forcing house of internationalism." Some of the most powerful images of Asian and African seamen-from Herman Melville's Moby Dick to Amitav Ghosh's Sea of Poppies-derive from this period, in which sailors of color were part of a large, broadly heterogeneous, international workforce. ${ }^{10}$

With the coming of steam power in the latter half of the nineteenth century, however, the nature and structure of maritime labor changed dramatically. If the wind-powered sailing ship could be described as a "prototype of the factory," the steamship was a factory fully formed. ${ }^{11}$ The move to steam power created, in one historian's words, "totally new categories of 
labor."12 Below deck, coal passers wheeled masses of coal from dark, cavernous storage bunkers to the ship's engine rooms; coal trimmers hammered away at these pieces to prepare them for the fire and then wheeled them to the mouths of the furnaces; firemen shoveled the coal into the fiery furnaces; stokers stood at the furnace doors, working the fires to keep them burning at optimum heat; and oilers and greasers moved from one part of the engine to another to keep the machinery functioning at maximum efficiency. ${ }^{13}$ This was industrial labor afloat, and some of the worst industrial labor of the era, with workers toiling in the depths of each steamship, as one Indian seaman described it, "thirty feet below the surface of the sea with no fresh air or daylight." ${ }^{\prime 14}$ By the turn of the twentieth century, these grueling engine-room jobs accounted for nearly half the positions on merchant ships, but in Britain, white seamen shunned engineroom labor and the "coolies" brought in to perform it; this was not the work of true sailors, they claimed, of skilled men of the sea. ${ }^{15}$

The transition from sail to steam threatened British shipping companies' dominance of seaborne trade. Other European nations now competed with Britain to build bigger and faster steamships, and British seamen successfully organized unions, developed allies in Parliament, and gained concessions on wages and working conditions. The British shipping industry responded by turning to the colonies as a source of cheaper and more controllable labor. ${ }^{16}$ Huge pools of workers were available to them in India, Egypt, Yemen, Malaysia, Somalia, and elsewhere, and it was here that they came to hire crews to work the engine rooms of their vessels and, ultimately, to cook in the ships' kitchens, serve in the cabins and mess halls, and clean the rooms and decks. ${ }^{17}$ By the turn of the century, Indians came to comprise the single largest group of colonial laborers working on British steamships; tens of thousands were hired out of the subcontinent's ports. The largest number of these men were Bengalis engaged from their home port of Calcutta. They were predominantly Muslims who hailed from villages in a few key regions, especially Sylhet, Noakhali, and Chittagong. Thousands of other steamship workers were engaged out of the port of Bombay where the seafaring population included men from Punjab, Kashmir, the Northwest Frontier, and Goa, while smaller numbers of men were hired in other ports, such as Karachi and Colombo. ${ }^{18}$ Although British shipping companies hired from all 
these groups and many others across the colonies, they divided their crews by language and region to minimize the likelihood of workers banding together against their white officers: on a large steamship, the engine crew might all be from one part of the world or the subcontinent, the saloon crew from another, and the deck crew from another. ${ }^{19}$ As seafaring became industrialized, British ships were transformed from sites of heterogeneity and intermingling into factorylike workplaces, with groups of laborers sharply divided along lines of race, ethnicity, language, and colonial subjecthood.

While the subcontinent had long traditions of seafaring, most Indian seamen of this era were from areas newly incorporated as supply centers for maritime labor. They came from villages that were often far inland from the main colonial ports of Calcutta and Bombay, where farming had been the main means of livelihood for generations. ${ }^{20}$ Their entry into the maritime trade was tied to a larger restructuring of the Indian economy under British colonial rule. Over the course of the nineteenth century, the British imposed private property and a new regime of taxation, which, coupled with recurring instances of drought and famine, threw members of the peasantry off their lands and spurred large-scale internal and external migrations. ${ }^{21}$ Hundreds of thousands of the poor, landless, indebted, and displaced migrated to the major colonial cities of Calcutta, Bombay, and Madras. In 1911, almost two thirds of Calcutta's population of 900,000 were in-migrants. Others-more than three-quarters of a millionmigrated across Northern India to work on Assam's tea plantations or in mines in West Bengal, while some of the poorest were recruited into indentured labor on plantations in the Caribbean, Fiji, Ceylon, Malaya, and Mauritius. ${ }^{22}$

The men who made their way to the docks of Calcutta and Bombay and eventually traveled across oceans to the waterfronts of London, Liverpool, New York, and Baltimore were, by and large, not the worst off of the uprooted, even if they became one of the most exploited groups of laborers on British steamships. Those who came from smallholding farming families were still working the land but struggling under the colonial regime to hold onto the property they owned..$^{23}$ Land taxes under the British were not only high, but also inflexible to yearly fluctuations in crop yield. Smallholders had to pay their taxes annually in full, even in 
the years that floods or droughts wiped out their crops. In these bad years, farmers borrowed from or mortgaged portions of their land to local moneylenders in order to pay their taxes. In good years, they often borrowed as well, to expand or improve their holdings. Over time, more and more smallholders defaulted on loans and had to give up their property, piece by piece, to cover their debt. Farming families saw their holdings dwindle as money lenders, larger property owners, and the British colonial state came to control more and more of the land that once supported them. ${ }^{24}$ According to historian Ravi Ahuja, it was "often the younger sons" of such families who were drawn into the maritime trade via networks of recruitment that stretched from Calcutta inland to rural districts like Sylhet, and from Bombay all the way into Punjab, Kashmir, and the Northwest Frontier. ${ }^{25}$ They entered the trade hoping to make enough money as coal-passers, firemen, cooks, and stewards to bring back to their home villages, repay their families' debts, and keep what remaining farmland they had from slipping into the hands of the money-lenders. In this sense, Ahuja and others have argued, the changes the British introduced on the sea were inseparable from those they wrought on land; the imposition of a colonial economy both unmoored these young men and redirected their labor. They moved from farms and villages to the industrial furnace rooms, coal bunkers, kitchens, and pantries of steamships that hauled away cotton, jute, tea, and other goods from the colony to the mother country and beyond. ${ }^{26}$

By the early twentieth century, the waterfronts of Calcutta and Bombay had swelled with such men, and the future that awaited them in the maritime trade was not an easy one. Faced with the combined power of shipping companies and the British colonial state, they entered the industry at a huge structural disadvantage. In the 189os, British maritime unions won a set of victories that required their employers to use a standard contract (British, or European, articles of engagement) that specified wages; guaranteed standards for hours, working conditions, food, and sleeping quarters; and provided compensation for work-related injuries. But the shipping industry exacted a key concession: workers hired out of Indian ports were not given the same protections and guarantees as their European counterparts. Indian workers were engaged on lascar, or Asiatic, articles-a form of agreement which was closer to indenture 
than to a contract between free parties. Under this two-tiered system of seamen's articles, British companies could hire Indian steamship workers at wages four to six times lower than those commanded by British seamen. They could provide lascars with food of lesser quality and quantity and cram them into bunks that were barely larger than coffins. There was no guaranteed compensation for Indian seamen if they were injured or for their families if they were killed on the job. When they signed on to a ship under Asiatic articles, these men were bound to work for the shipping company not just for the duration of one journey, but for a contracted period of one or two years. During that time, the shipping company could pass them from ship to ship; the Indian men had no right to leave their employment, no matter what the circumstances or conditions, until their contract was over. And when the contract was over, shipping companies were required to return lascars to the subcontinent, ensuring that they could not access the rights and wages available to seamen who were hired out of British and other European ports. ${ }^{27}$

When a prospective seaman traveled from his home village to the port of Calcutta or Bombay, he thus found a system that was structured against him in multiple ways. But the contracts that would define his working life were only part of this system. There were up to three times as many workers as there were jobs on outgoing ships-a situation that helped shipowners keep Indian workers "docile" and wages low. ${ }^{28}$ The British colonial government banned the formation of labor unions on the subcontinent, hampering Indian maritime workers' efforts to address their lot collectively well into the $1920{ }^{29}{ }^{29}$ Prospective seamen not only faced months of waiting, searching, and competing to get signed on to ships, but also had to navigate an arena of middlemen that the authorities did little to regulate. There were the ghat serangs, men who ran dockside boardinghouses and acted as employment brokers for British shipping companies, and the serangs, men who assembled outgoing crews, signed these crews on to a ship, and then managed them on board for the duration of each contract. ${ }^{30}$ Individual seamen had to make payments to serangs in order get onto their crews, and when they returned to their home port at the end of a journey, they also had to pay off their debts to the ghat serangs who had provided them room and board during the long periods they were unemployed. ${ }^{31}$ 
Accounting for a year's pay in the 1910s, one Indian seaman wrote: "In addition to the two months' wages that would go towards the Sarong's bribe and various other collections, at least one month's pay would be needed for working clothes . . . and other necessities. Two months' earnings were required for the [boardinghouse keeper] at whose home one lived on credit while searching for a job, and it took almost one month's pay to cover train fare and other traveling expenses in returning to one's village. . . . Thus, toiling under degrading and unhealthy conditions for an entire year, the best that one could hope for would be to have sixty or seventy rupees left over." Given what was at stake, however, most seamen had little choice but to work within the system's constraints. The sixty or seventy rupees, "would be most welcome as it helped pay back the userer's loan. ... This saved a few acres of land from being expropriated by moneylenders or the state." 32

For the thousands of Indian seamen who successfully secured work on outgoing ships, things were hardly better at sea. Engine-room labor was particularly brutal. Recalling his experiences on a series of voyages outward from his home port of Bombay, Dada Amir Haider Khan writes: "Working in the coal bunkers through the Red Sea was [s] uch hell that the firemen had to pour buckets of sea water over their bodies before opening the furnace door to throw coal inside, or rake the fire. By the time they finished a round, their overalls would already be dry. Immediately they would douse themselves again with sea water. . . Still, some firemen, scorched and asphyxiated, had to be carried to the decks by their workmates with others taking their places." ${ }^{93}$ Such work took a harsh toll, both mentally and physically, on colonial laborers. At the turn of the century, British and American newspapers were littered with stories of "lascar" sailors "going mad" after hours in the stokehold. In one instance, the New York Times recorded the effects of a heat wave on two workers of the SS Haleric as it passed between Calcutta and Colombo. The heat had driven one man "crazy" and sent the other overboard. "The crazed man," wrote the Times, "was at work in the boiler room at a time when the deck temperature was 108, [and] complained of feeling dizzy. He came up on deck and began to circle crazily. Just as he started to ... lunge at one of the [white] engineers who had followed him, he was seized" and "pinned to the deck by British officers." The 
second man "staggered to the ship's side and was in the water before his absence was noted. ... Though the ship circled for two hours, he was never found." $" 34$ Tragically, this seaman was not alone in his death; as Ahuja has noted, British colonial records show "a remarkable recurrence of the theme of lascar suicides, especially among firemen," from the turn of the century through the 1930 s. $^{35}$

British shipping companies justified their exploitation of Indian workers with a racial mythology that portrayed men from the colonies as inferior to Europeans. Indian men were "weaker," "less capable" sailors; the companies thus claimed they had to hire several Indians, at lower wages, to do the work of a single European. Indian men were also more "suited" to the heat of the boiler room (because they were accustomed to a "tropical" climate) or to servile and domestic tasks above deck. These ideas were reinforced by the attitudes of white British seamen. Although firing and stoking a ship's furnaces and monitoring, regulating, and maintaining the steam in its boilers required a combination of strength, stamina, and skill, this work was derided by British sailors as "not seafaring . . . it is arduous, dirty and hot ... with no seagoing traditions to support it" - and thus fit only for lesser workers. The labor of those in the saloon and catering crews was simply "dismissed as 'women's work." " ${ }^{\prime 36}$ The prevalence of illnesses such as tuberculosis, pneumonia, ulcers, and fevers among Indian sailors was also explained in racialized and gendered terms, "attributed to their [natural] lack of stamina not to their inferior rations or their appalling conditions of service." "In the shipboard mythology," writes historian Rozina Visram, "lascars became inferior, lacking in masculinity, self-reliance and initiative ... [and] could [only] make excellent seamen ... when led by European officers." ${ }^{\circ 38}$ In fact the one-sidedness of Asiatic articles left British officers free to work their Indian crews relentlessly. Ships' masters wielded "practically unlimited control over the person of the lascar, who risked being charged with breach of contract if he refused to be at the disposal of the shipmaster at any time, either when the ship was at sea or when it lay in port." 39

Still, Indian seamen consistently pushed at the boundaries of the maritime system. As they moved through the circuits of imperial trade, a significant number of these men succeeded in outwitting the shipping 
companies and their officers and used the industry to expand their opportunities beyond the subcontinent. They moved from port to port, shifted back and forth between maritime and onshore work, and pursued better wages and working conditions in countries far from their homes. ${ }^{40}$ There were many ways they could make use of their mobility once at sea. In order to supplement their meager wages, seamen commonly engaged in small-scale trade-or in the words of one sailor, "buying cheap" in one location and "selling dear" in another. This kind of activity did not always require seamen to travel great distances. One group of Indian seamen who were docked near the port of Basra in the midst of the First World War made money catering to the basic needs of soldiers passing by on their way to the battlefront. The seamen

would obtain leave from the[ir serang] in exchange for a share in the profits, engage small row boats, and ... purchase a variety of fruits such as grapes, oranges ... raisins, dates, and pomegranates [from fruit sellers onshore]. After loading the local fare into small boats, they would station themselves in the middle of the river and greet [the] incoming troop ships that would arrive daily in Basra loaded with soldiers from India and other theatres of the war. These men could often not stomach the tasteless food provided aboard their ships or would be suffering from sea sickness. They were happy to pay whatever they had for these fresh fruits. ${ }^{41}$

In the 1920s, British authorities were alarmed by another trade that Indian seamen had developed that was global in its scope and threatening in its implications. In a letter to the Intelligence Bureau of the British colonial government, Bombay's commissioner of police claimed that Indian seamen "import cocaine from Kobe, Japan, and sell at a profit in Bombay. With the proceeds, drugs, mostly charas [hashish], are bought in Bombay and taken to Port Said [in] Egypt where they are sold at a profit; with the proceeds of these sales, arms are bought in Marseilles and taken to China, where their disposal is not so difficult and likewise profitable." 42 A little more than a decade later, during the Second World War, Indian seamen in British ports took advantage of the local system of ration coupons; they "used to go to the ships-[in] Tilbury, Liverpool, 
Cardiff-and buy coupons from [departing] sailors-they didn't need them [anymore] - and then get sweets, chocolates, clothes, and sell them around the factories [on the] black market." 43

On board ship, Indian seamen engaged in everything from petty theft to mutiny. Dada Khan describes instances in which he and his coworkers stole goods from their ships' storeroom either to trade for fish and meat in different ports or simply to eat when their officers were depriving them of sufficient food. ${ }^{44}$ On one voyage, a sixteen-year-old Khan crawled through an air shaft in his ship's storage area to steal onions and potatoes. A shipmate then cooked them up with ghee and spices to feed the Indian crew. ${ }^{45}$ Seamen were not always so nonconfrontational, however. In 1890, the New York Times described the case of a British ship, manned by a "mixed" crew, whose Indian cook unilaterally stopped working two days after the ship left Dundee, Scotland. "The Captain sent for him," the ship's first mate told the Times, and two hours later, the captain was found stabbed to death, slumped in a pool of his own blood, with the cook reportedly sitting nearby with a knife in his hand, "crouched like some wild animal ... upon a large flower pot of geraniums which he had ruthlessly crushed beneath him." ${ }^{46}$ An article from 1913 tells a similar story, of "four Hindu seamen ... of the Mohammedan faith ... [who were] charged with killing . . . an assistant engineer on the British steamship SS Kundia, ${ }^{947}$ and a story from 1930 describes a "riot" on board the SS Irisbank, in which "Lascar stokers and oilers of the vessel's crew attacked their superiors with crowbars, shovels and belaying pins ... shortly before the ship was to have sailed." 48 While American newspapers described the sailors' actions as "murders" and "riots" and the men involved were described as "irrational" and "deranged," such events were clearly rational, if desperate, responses to the severe conditions and daily indignities these men faced on board.

Desertion was another step that Indian steamship workers took in the face of such conditions; it was at once an assertion of agency, a reassertion of humanity, and a denial of labor to those who would relentlessly exploit it. In her Asians in Britain: 400 Years of History, Rozina Visram tells the story of a crew of Indian Muslim seamen who found themselves at the mercy of a violently sadistic ship's officer. "They had been 'hung up with weights tied to their feet', flogged with a rope and forced to eat pork. 
The $[n]$. . . the tail of the pig had been 'rammed' into their mouths and the entrails twisted around their necks." Upon arrival in London, the entire ship's crew deserted en masse. "Desertion," writes Visram, "was ... akin to an act of resistance." 49 At the same time, Visram and other historians of the era have made clear that "jumping ship" was not an easy matter, nor was it simply a spontaneous act that seamen undertook to escape the harrowing conditions on specific vessels. It was one of a larger set of strategies that Indian and other colonial maritime workers developed in order to gain greater control of their lives and labor, particularly once their ships had reached British ports, where they could assert a set of rights as subjects of the Empire. In some instances, men jumped ship in order to work at higher-paying factory or service jobs in British cities and then returned to the maritime trade after a stretch of months or years. For other colonial seamen, desertion was a means of gaining higherpaid maritime work; after deserting in port cities like London, Cardiff, Liverpool, and Glasgow, they used their status as British subjects to establish residency in the United Kingdom and then reentered the industry on British rather than lascar articles. This allowed them to access the higher wages and greater protections that European articles guaranteed. ${ }^{50}$ Still other men from the colonies went a step further, successfully mobilizing their status as subjects of the Crown to remain in Britain-to live and work there for good. ${ }^{51}$ As G. Balachandran has put it, deserting seamen were able to turn the British steamship to their own ends, to give "an instrument of control . . the sharp edge of dissent."

Shipping companies watched their workers closely and policed their movements while in port, but over time, hundreds of Indian, Arab, African, and Chinese seamen successfully jumped ship, and distinct multiethnic enclaves began to develop in many of Britain's major port cities. Some of the earliest men to desert successfully in the 1890 os and early 1900 s married local working-class British women and, with their help, opened boardinghouses, restaurants, and cafés. ${ }^{53}$ This meant that by the time of the First World War, when tens of thousands of Indian seamen were sailing into and out of British ports on merchant and supply ships, these men could access established networks of local men and women who would help them jump ship and find work onshore. ${ }^{54}$ During the war, jobs were also plentiful. Indian men found more oppor- 
tunities to sign on to ships in British ports at British wages, and Indian and other colonial workers were in great demand onshore in steel and munitions factories, sugar refineries, and shipbuilding firms. Shipping companies and onshore industries now openly competed for Indian workers, with the former accusing the latter of "entic[ing] sailors away by offering higher wages than under ships" articles. ${ }^{955}$

At the end of the First World War, dockside settlements of workingclass Indian, African, Arab, and other Asian men numbered in the hundreds and, in larger ports like Cardiff and London, in the thousands. ${ }^{56}$ Indian seamen sailing into Britain, however, found a less welcoming and hospitable environment. When thousands of white British seamen returned from their war service and sought to reenter the maritime trade, British port cities experienced a wave of riots aimed at driving out "coloured seamen." Afterward, the British government launched a series of its own efforts, as historian Laura Tabili puts it, "to uproot Black residents from Britain by persuasion or compulsion." " African, Arab, and Asian residents of dockside settlements were now required to "produce documentary proof of British nationality" and to register as aliens and faced heightened policing and harassment. ${ }^{58}$ In this context, local networks became the key to the survival of Indian seamen and exseamen in Britain. Networks of boardinghouses, private homes, restaurants, and work sites not only provided escaped seamen with places to live and work under the radar of local authorities, but also enabled the circulation of people, knowledge, and information from one locality to another and back out into maritime circuits that stretched all the way to the subcontinent. ${ }^{59}$

\section{At the Nation's Edge}

In recent years, British historians, ethnographers, and genealogists have built an increasingly detailed picture of the Indian men who jumped ship in Britain and the communities they formed onshore in places like East London, South Shield, Cardiff, and Liverpool-some of the first South Asian communities in all of Europe. It is clear that many Indian seamen chose to jump ship in British ports because of the colonial relationship between Britain and India-because Indians could make claims to 
live and work in the United Kingdom that they could not make elsewhere. But by the early twentieth century, Indian seamen were traveling to ports all over the world, including the United States. In the years that newsmen in Galveston, Baltimore, Philadelphia, and New York were providing American readers with descriptions of the "queer customs" of "Hindoo seamen," these seafarers were bringing descriptions of Galveston, Baltimore, Philadelphia, and New York back to their families and fellow workers on the subcontinent. This information appears to have included news of the opportunities that were available in U.S. port and factory towns for those seamen who could successfully jump ship. It also likely included details about the laws pertaining to Asian immigrants and seamen, the practices of shipping companies and U.S. authorities to prevent desertion, the strategies that seamen had developed to outwit the shipping companies and the authorities, and the names and locations of people onshore who could help deserting seamen find lodging and work.

Over time, a seaman departing from Calcutta or Bombay with hopes of finding work elsewhere engaged in a complex calculus about where, when, and how to jump ship, and U.S. ports were part of the equation. This was the case, for example, with Shah Abdul Majid Qureshi, a seaman from Sylhet, East Bengal, who settled in London only after trying and failing to jump ship in New York in $1935 .{ }^{60}$ In an interview with ethnographer Caroline Adams in the 1980s, Qureshi described both Britain and the United States as destinations that his contemporaries sought to reach through the maritime trade; these were places that many of them had in mind for desertion, even before they left the subcontinent. In Qureshi's case, it was the success of co-villagers who had jumped ship in the United States that drew him into maritime work in the first place: "My aim was to get a job in the sea and either go to America or to England. England was not much attraction to meAmerica, at that time America was the attraction, because ... [t]hose who managed to escape and somehow settle in America, they always used to send [home] big money orders. Some of them came back [to the village] and that gave me the idea that we were poor, down and out ... if I could manage to go to America, somehow or other I could earn enough money - that was my ambition. ${ }^{" 61}$ Qureshi did sign on to a ship 
that was bound for the United States, but because he was literate and had more education than his shipmates, his British officers considered him a risk, denied him shore leave in New York, and closely watched him for the days they were in port. But hundreds of men succeeded where Qureshi failed, both before and after him.

The barriers these men faced were considerable. Both British and U.S. maritime unions wanted to keep low-wage Indian seamen out of their members' home ports and off their primary sea routes, and both fought hard to pass laws and influence public opinion to achieve their goals. British seamen's organizations won an early victory when they secured the inclusion of the "lascar line" provision in the 1894 Merchant Shipping Act. This provision forbade British steamship companies from employing Indian workers on voyages to Atlantic ports above 38 degrees north latitude-Baltimore, Philadelphia, New York, and Boston-between October and March of every year. The unions drew on the racial mythology surrounding Indian seamen to justify this clause, arguing that the warm-blooded Indians could not withstand the work on these routes during the "winter months" and asserting that the provision would protect them from illness. In fact, the British unions sought to discourage the hiring of Indian workers on U.S.-bound ships entirely and to make the North Atlantic routes the exclusive province of white seamen-at least for six months of each year. ${ }^{62}$ To comply with the provision, British shipping companies with Indian crew members would have to drop these men off in the southern port of Newport News, Virginia, put them up in boardinghouses at the shipping companies' own expense, temporarily hire other seamen to work in their place, proceed up the coast with this alternate crew, and then return to pick up the Indian crew from Newport News before making their return trip. Although some shipping companies did go through this routine, the unions' goal seems to have been to make the process so cumbersome and costly that British shipping lines would be compelled to employ white British seamen instead of Indians on U.S.-bound journeys to avoid the extra time and expense. ${ }^{63}$

U.S. maritime unions were also doing their best to keep Indian seamen out of the United States. Among U.S. labor leaders, one of the most vociferous opponents of Asian immigrant workers was Andrew Furuseth, the head of the San Francisco-based International Seamen's Union. 
While remembered as the heroic architect of the 1915 Seamen's Act, which regulated wages and working hours and set health and safety standards for American maritime workers, Furuseth was also one of the founding members of the violently xenophobic Asiatic Exclusion League in $1905 .{ }^{64}$ For decades, until his death in 1938, this Norwegian American agitated for the exclusion of Asian immigrants from the United States and of Asian seamen from ships entering U.S. ports. At Furuseth's insistence, the Seamen's Act included a language requirement for crews moving in and out of U.S. ports that was aimed specifically at keeping Chinese and Indian seamen from either working on American merchant ships or entering the United States on foreign ships. Furuseth also made dramatic and repeated claims in public and in congressional hearings that Chinese and "Hindu" seamen were sneaking into U.S. ports by the thousands and engaging in the large-scale smuggling of people and drugs. His testimony helped fan the flames of the growing moral panic about an America "flooded," "swamped," and "infiltrated" by Asian immigrants, sentiments that ultimately led to the passage of the Asiatic Barred Zone provisions of the 1917 Immigration Act. ${ }^{65}$

The 1917 act raised the stakes even further for Indian seamen who attempted or hoped to jump ship in the United States. While best known for its anti-Asian provisions, the 1917 act also included a series of clauses intended to tighten U.S. borders by policing the movements of foreign seamen while they were in U.S. ports. These clauses created a system for tracking all noncitizen seamen arriving in and departing from U.S. ports, defined classes of seamen whom foreign shipping companies were not permitted to land or discharge in the United States, and set steep fines for shipping companies who brought barred immigrants into the country in the guise of seamen or failed to prevent the desertion of their workers while in port. Although these provisions pertained to seamen from Britain, Norway, Greece, and other European countries, the combination of the anti-Asian and the alien seamen's clauses of the 1917 act established a particularly strong set of regulations for seamen from India, China, and other parts of the "barred zone."66

The 1917 legislation placed the burden of surveilling and controlling Asian seamen on the shoulders of their employers. It specified that the "negligent failure" of a shipowner to "detain on board any . . . alien ex- 
cluded from admission into the United States," would make the owner liable for a penalty of $\$ 1,000$ per deserting seaman and could result in his ship being seized by immigration authorities until the fine was paid. ${ }^{67}$ As a result, Indian seamen faced even greater policing by their ships' officers than they had before 1917 while in port in the United States. For those who might elude their employers, the threat of imprisonment in and deportation from Ellis Island was also a clear disincentive to desertion. As the new legal regime went into effect after 1917, news traveled through maritime networks of the conditions and treatment that captured Indian deserters experienced at Ellis Island. Ahuja describes the case of a group of Indian seamen who jumped ship in New York in 1921 in order to bring suit against their employers for denial of sufficient clothing and food rations. The New York Globe reported that the "lascars" were "panic stricken" at the idea of being sent to the Bureau of Immigration and Naturalization's holding cells at Ellis Island: "Through an interpreter, they said they knew all about this terrible place, and would not go there." ${ }^{968}$

Together, these varied laws, mechanisms, and practices added up to a formidable set of barriers; on their face, they should have ensured that few Indian seamen were even sailing into the major ports of the U.S. Atlantic coast and that, at least after 1917, those who came were held on board their ships and not given the opportunity to desert. But this was not the case. Indian seamen did make their way to ports along the Eastern Seaboard, they did step onshore, and many found ways to leave their ships and stay. There were other forces at work in the 1910s that made desertion in the United States not only possible for Indian maritime workers, but also worth the risk. In 1902, British shipping companies successfully lobbied their government to partially repeal the "lascar line" provision of the Merchant Shipping Acts, so that they could use Indian engine and saloon crews below deck on winter voyages to U.S. Atlantic ports. They then convinced the British Government to drop the ban entirely for the duration of the First World War, which allowed them to use Indian crews above deck as well. There is evidence that major British shipping lines continued this practice on voyages to New York for more than a year after the war's end. ${ }^{69}$ Thus, as a result of British companies' efforts, the number of Indian seamen sailing into U.S. Atlantic ports rose 
after 1902, and for an extended period in the late 1910 s and into 1920 , these companies employed Indian engine and deck crews on voyages to U.S. Atlantic ports all year round. Manifests show that, throughout this latter period, ships operated by the Ellerman Line, the Clan Line, and the Cunard Line regularly made runs into New York during the winter months using low-wage "lascar" crews, sixty, seventy, eighty men at a time. ${ }^{70}$ In January 1919, for example, eight British steamships brought more than 450 Indian engine-room and saloon workers into the port of New York in a single month. The vast majority of these workers were Bengali Muslims-from Sylhet, Noakhali, Myensing, Tipperah, and Calcutta. ${ }^{71}$ This month was on the high side, but the shipping companies in question appear to have been consistent in their use of Indian workers; through the winters of 1917 to 1924 , between 50 and 300 Indian seamen arrived at the New York waterfront on British ships every month. Because Indian crews were sailing into New York with even greater frequency during the spring and summer, these numbers added up. In the decade between 1914 and 1924 alone, 20,000-25,000 Indian steamship workers moved in and out of New York's docklands. ${ }^{72}$

These men were arriving at the United States' maritime borders during a large-scale expansion of U.S. industry. In the years before the United States' entry into the First World War, between 1914 and 1917, U.S. industries were supplying their European allies with millions of dollars worth of munitions, fuel, ships, and other goods and materials vital to the war. When the United States officially joined the conflict in 1917, the country's factories, shipyards, and steel mills were operating at full steam. The entry of thousands of young American men into the military created a labor shortage that U.S. industries addressed by hiring women, African American migrants from the U.S. South, and immigrants. ${ }^{73}$ While the flow of immigrant workers was significantly curtailed by the 1917 Immigration Act, Indian and other seamen had a unique advantage. Most arrived in U.S. ports as experienced industrial laborers; they had a well-honed set of skills working with furnaces, engines, and machinery. This appears to have made them especially desirable to U.S. factory owners, who, just like in Britain, began to recruit members of the Indian and Chinese crews of ships passing in and out of New York, Philadelphia, and Baltimore. In the years immediately fol- 
lowing the war, as U.S. labor unions mounted a series of regional and nationwide strikes, factory owners continued this practice, hiring Indian and Chinese seamen off the docks and using them alongside African American workers as strikebreakers. ${ }^{74}$

Both British shipping companies and U.S. industries were bending and breaking their countries' laws in pursuit of Indian seamen's labor. The steamship lines were pushing back against Britain's Merchant Shipping Acts in order to use Indian workers without restriction on ships bound for North Atlantic ports, and U.S. munitions, steel, and auto companies were violating immigration and labor laws by enticing Indian workers off the waterfronts to work in their factories. For these men from Bengal, Punjab, and the Northwest Frontier, U.S. immigration law was a wall that was supposed to separate the maritime and onshore industries, to prevent workers moving from one to the other. But the pursuit of profit by powerful interests on both sides ensured that the wall would not be impermeable. These industries' efforts and violations created opportunities for workers from the subcontinent both to reach U.S. ports and to escape their ships for higher-paying factory work onshore.

To be sure, those who successfully took this route often found themselves in situations that were only nominally better than what they had experienced in the maritime trade. Dada Amir Haider Khan's experience after jumping ship in New York in February 1918 is a case in point. In the weeks following their desertion, Khan and one of his shipmates failed to find work, and with dwindling resources, limited skills in English, and barely enough clothing to keep them warm, the two fell prey to one of the city's unscrupulous labor recruiters. This middleman and his team of "employment agents" were rounding up unemployed immigrants from throughout the city to supply to New York-area factory owners. "He told us to sit down in a hall where there were some benches," writes Khan, "while a few more groups were brought in from elsewhere by some of his agents. ... We were [then] herded together and put on a train for some unknown location." This, it turned out, was one of DuPont's wartime munitions plants in New Jersey-most likely their sprawling complex of factories at Carney's Point. Here, according to Khan, immigrant workers were housed in row after row of wooden barracks with "cots resembling ships bunks." They worked long shifts 
"sorting and separating some peculiar brownish coloured ingredient, like Italian spaghetti," were paid 30 cents an hour in a combination of cash and company scrip, and were policed by the compound's "own militia, secret service, [and] officials responsible for discipline and enforcement of rules." Like many of the spaces through which Indian men moved after deserting, the factory was wildly heterogeneous; Khan worked alongside Italian, Spanish, Polish, Russian, and Eastern European workers but was domiciled with the Puerto Rican "camp" since "there were not enough Indians for an Indian camp." "We [were] just like all the other ignorant, illiterate, poverty-stricken men employed at the plant," Khan wrote. ${ }^{75}$

A group of Indian and Chinese seamen found themselves in an equally dire situation after the war, emerging as targets of violence during a 1922 railroad shop-workers' strike in Jersey City, New Jersey. These workers stepped off the waterfront directly into the racial politics that would define U.S. interwar labor struggles. As soon as the strike had started, the Erie and Lackawanna Railroads sought out low-wage, nonunionized Indian, Chinese, and African American workers to sidestep white workers' organizing efforts. A series of local employment agents quickly emerged, who supplied the railroad owners' needs by canvassing the docks and facilitating the desertion of Indian and Chinese seamen to take up strikers' jobs in the railroad's steam-power shops. As a result, at the end of the first week of the strike, most of the violence that had arisen was not between workers and employers but between the striking white workers and their Asian and black nonunion replacements. ${ }^{76}$ It is unclear whether these seamen knew when they took the rail-yard jobs that they were being thrown into the middle of a labor dispute. According to a Jersey City police captain, "a Bowery employment agency had promised [Indian and Chinese seamen] \$3 a day and lodging and meals." After they were brought across the water from Manhattan, these men were housed in buildings within the rail-yard compound, where "close guard was being maintained over the imported men" by an armed security force that the Erie Railroad had hired. The seamen, however, were put upon by all sides. The Indian workers, according to the police captain's report, had to be "rescue $[\mathrm{d}]$. . . from a mob which was threatening them with clubs and stones." Significantly, the Jersey City police neither arrested the 
Asian seamen nor did much to prevent them from coming back. Nor did federal immigration officials cite the Erie Railroad for hiring "alien" workers in violation of the labor and immigration laws or go after the "Bowery employment agents" for their role in this violation. ${ }^{77}$ When an industrial concern as large as the Erie Railroad needed to use Asian seamen to ensure the continuation of rail services in the face of a strike, local and federal officials were apparently willing to look the other way, letting the railroad's agents and hired guns circumvent the laws as they saw fit and concentrating their own energies on simply keeping things from boiling over into violence. Asian seamen, for their part, were largely left to fend for themselves.

\section{Clandestine Networks, Onshore Worlds}

While Indian maritime workers found an unwelcoming, even hostile, environment awaiting them in the United States-one in which they faced the controls of their ships' officers, the punishments of immigration officials, the ire of white labor unions, and the exploitation of industrial employers - they were able to navigate this environment and benefit from the options for working onshore by building networks of kin, fellow workers, and local residents that stretched from the waterfronts of Atlantic port cities far into the industrial heartland of the United States. The networks took root between 1914 and 1917, in the brief window of time after U.S. factories had shifted into wartime production and before the restrictions of the 1917 Immigration Act tightened the reins on Asian immigrants and "alien seamen." As in Britain, these networks were rooted in a population of ex-seamen whose presence onshore grew steadily in the final years of the nineteenth century. As early as 1900, the New York Post noted a small "colony" of Indian seamen living in the sailors' boardinghouse district at the southern tip of Manhattan, where the "lascars" shared quarters with other maritime workers from the Middle East, Singapore, and the Malay peninsula. ${ }^{78}$ While this was likely a transient population of men who were moving on and off the ships, in the 1910s some of the seamen began to make their way inland to work factory jobs in New Jersey, Pennsylvania, upstate New York, and beyond. The first of these men may have been recruited 
by agents working for specific factories, but by the time wartime production reached full stride, Indian seamen had built up their own circuit that stretched through multiple factory towns across hundreds of miles and several state lines. When immigration laws subsequently tightened, the Indian presence throughout this circuit was already well entrenched; in New York, Philadelphia, and Baltimore and in at least a dozen major factory towns, there were groups of ex-lascars, some of whom had married local women; in each location there were shared apartments and boardinghouses; and in the factory towns, there were avenues for newcomers to secure work-in steel, in shipbuilding, and on automotive assembly lines. Twenty years earlier, Hooghly's peddlers had created a network that tied together multiple sites of tourism, commerce, and consumption; now these seamen created a network that connected multiple sites of industrial production. The infrastructure they laid down enabled a steady stream of escaped Indian seamen to work in U.S. factories for the duration of World War I and for many years afterward and allowed these men to live and work under the radar of the new anti-Asian immigration regime. ${ }^{79}$

While the Bengali peddlers had moved southward into Louisiana, South Carolina, Georgia, and Texas, the seamen moved in an arc north and westward from the Atlantic coast. Many of the factories and mills to which they traveled were close at hand. In Patterson, New Jersey, just across the Hudson River from Manhattan's West Side waterfront, Indian ex-seamen found a niche stoking the fires that heated vats of dye in the town's silk-manufacturing plants. In Hamilton, New Jersey, thirty-five miles up the Delaware River from Philadelphia's waterfront, they worked in the Zonolite asbestos factory. In Chester, Pennsylvania, just fifteen miles downriver from Philadelphia and eighty miles from Baltimore, Indian ex-seamen worked in the Sun Shipbuilding Company's shipyard and on the assembly line of a Ford auto factory. In Bethlehem, Pennsylvania, not more than a day's journey for a seaman who had jumped ship in Philadelphia, New York, or Baltimore, Indians worked in Bethlehem Steel's massive steel-production compound. Other opportunities took these men farther afield: dozens of Indian seamen made the 400-mile journey into the colds of upstate New York to work in the Lackawanna (later Bethlehem) Steel plant near Buffalo; others traveled deep into the 
Midwest to work in U.S. Steel's mills in Youngstown, Ohio, and Gary, Indiana, and the Ford, General Motors, and Packard auto factories in Detroit and Dearborn, Michigan. ${ }^{80}$

During the 1920 s and 30 , some of the largest populations of Indian factory workers were in these more distant locations: particularly Buffalo and Detroit. The former was the site of what was then the largest steel plant in the world, operated until 1922 by the Lackawanna Steel Company. This plant came to occupy more than 1,000 acres of land; it had, according to one description, "its own ship canal, locks, bridges," and railway lines and produced steel "bars, sheets, rail, tie plates" and fabricated parts for construction and other industries. ${ }^{81}$ By 1920, there was already a well-established infrastructure for escaped Indian seamen to live and work in Lackawanna. Two men who had arrived in the United States in the early 1910s-one an Indian named Meah and the other listed as "East Indian" but whose name, Abdul Djebara, suggests he may have been Arab-ran boardinghouses for Indian workers on Fifth Avenue and Ridge Road, just outside the steel plant's doors. On the day federal census takers came around to these addresses in January 1920, Meah was lodging two dozen men and Djebara another dozen; they were all young, between eighteen and thirty-five, all had entered the country over the course of the war, between 1914 and 1919, and all now worked as firemen, likely stoking the flames that turned iron ore to molten steel in the Lackawanna plant. ${ }^{82}$ At the peak of the war, draft registrars recorded close to fifty Indian men who were engaged in this work at Lackawanna. They had come from the precise demographic of the Indian maritime population: all were Muslim, they were predominantly from Bengal, and one member of the group was even known by the surname "Serang"-indicating his former occupation as the headman of an Indian steamship crew. Few of these workers appear to have had formal education; eight signed their draft cards in rough Bengali, one signed in clearly drawn English script, and the rest were unable to sign their names in either Bengali or English, instead marking the bottom of their draft cards with an $X$ or a check mark. The men had, however, turned the skills they had developed in the boiler rooms of British steamships to equivalent and probably better-paid work in steel production. ${ }^{83}$ 
In Detroit, the number of Indian ex-seamen working in Ford auto factories grew in the immediate postwar period and continued through the $1920{ }^{84}$ As in Lackawanna, this Indian presence was built on a network of ex-maritime workers, boardinghouse keepers, and others who guided escaped seamen from New York and other port cities to Detroit and set them up with lodging and factory jobs. Here, they joined multiple streams of labor migration. By 1930, Detroit's Ford plants and the city's working-class neighborhoods and rooming houses were full of workers from all over the country and all over the world: African Americans who had come north as part of the Great Migration, as well as Afghans, Arabs, Syrians, Turks, Greeks, Maltese, Poles, and other immigrants from Europe, the Middle East, and the Americas. Although Indian men usually roomed together, they lived in buildings and areas that they shared with all these other groups. ${ }^{85}$

Over time, most came to live in a series of Indian boardinghouses and group households in a corner of the working-class African American neighborhood of Black Bottom on the east side of downtown Detroit. On their immediate blocks, their neighbors were predominantly Greek and Muslim immigrants; three or four blocks to the north was one of Black Bottom's main entertainment and commercial districts, around St. Antoine Street and Gratiot Avenue, which was home to a variety of African American small businesses, nightclubs, restaurants, and vaudeville and movie theaters. On the blocks beyond, to the north, east, and south were the residential areas of Black Bottom and Paradise Valley, where, as a result of the city's segregation, up to three hundred thousand southern black migrants came to share some of Detroit's poorest housing. ${ }^{86}$ In the 1920 , one of the ex-seamen opened a small Indian restaurant here, possibly Detroit's first, which became a place of congregation for the city's workers from the subcontinent. ${ }^{87}$ Whereas in Lackawanna, most of the Indian men were able to translate their existing furnace and engine-room skills directly from maritime to factory labor, the Indians in Detroit became part of a new industrial paradigm; they were deskilled and spread out across countless individualized tasks. On 1930 census sheets, their jobs read like an enumeration of every position on the Fordist assembly line: "Abdul Wahid-tool maker," "Mohammed Khan-molder," "Noor Alli-drill press," "Asod Ali-punch press," "Ishak Ali-motor assem- 
bly," "Abdul Karim-ignition assembly," "Sefit Ali-body builder," "Jamshed Ali-oiler," "Ali Ullah—sander," "Idris Ali-polisher."88

The population of Indian ex-seamen laboring in places like Lackawanna, Detroit, Chester, and Youngstown seems to have been in constant flux; men came and went from each city, and some worked in multiple industrial locations over the course of the months or years they spent in the United States. Onshore networks not only created conduits for men to travel from port cities to individual factory towns but also connected factory towns to one another; the communication and coordination among former seamen in these places was such that deserters could keep moving from one factory town to another, sometimes with stints at sea in between. The story of Mustafa "John" Ali, a Bengali seaman who spent several decades in the United States, illustrates just how mobile these men could be. Ali jumped ship in Baltimore in the early to mid-1920s, worked onshore for a time, then reentered the maritime trade, worked his way back to India, and returned to his village in Sylhet. In the late 1920s, Ali set out again for Calcutta, secured work on an outgoing steamship, and when his ship got to Maryland, he deserted a second time and settled in Baltimore, where he married an African American woman and had three children. In the 1930s, he left his family in Baltimore to work in the Ford auto plant in Chester, then traveled north to Buffalo to work in the Bethlehem Steel works, then returned to Baltimore to move his family back with him to Chester, where he worked either for Ford or for Sun Shipbuilding during World WII. After the war, Ali moved his family back to Baltimore, while he went to work first at the U.S. Steel plant in Gary, Indiana, and then in a General Motors auto factory in Detroit. When he retired from General Motors in the 1950s, Ali went back to his village in Sylhet. ${ }^{89}$

In order to achieve such mobility, Indian seamen needed to know or learn certain things-how to elude ships' officers, how to time a desertion, how and where to lay low until their ships left port, where to go for work-and they needed the help of others who were already living onshore, people who would put them up in the short term, feed them and hide them from authorities, and direct them to other people and locations that were often many miles away from the places they jumped ship. Some men may have planned to desert and had a specific destination in 
mind-Buffalo, Bethlehem, Youngstown, Detroit-before they even reached U.S. shores. These men might have communicated with friends or family who were already in the United States or might have learned about these American industrial towns from shipmates once they were at sea. ${ }^{90}$ Other deserters may have heard of such places only after they jumped ship and were directed to the factories and steel mills by recruiters or by the Indians who were living onshore in New York, Philadelphia, or Baltimore. Whatever the case, most first-time deserters would have arrived in the United States with hardly anything in hand. Their British employers gave them work clothes that were thin, ragged, and largely inadequate to the northeastern weather. Lascar crews were not paid off fully until they had reached the end of their contracts and returned to their home ports, so these men would have had little to no money on hand when they jumped ship. ${ }^{91}$ Most had minimal Englishlanguage skills and very little knowledge of where to go once they were onshore. So, after deserting, they first needed a place to hide, food to eat, and a new set of clothes. Then, when they set out for one of the factory towns, they needed directions for travel and an address and person to go to on the other end.

Physically, onshore networks began with the ships and docks and extended inland through various spaces: lodging houses and residences, factories and other job sites, and places of gathering and leisure. They were also chains of people-countrymen, kinsmen, and allies who provided deserters with assistance and information as they passed through these spaces in a series of steps, from the moment of desertion at the waterfront to a period of hiding in the port city to the subsequent journey to a factory town to the navigation of daily life in the context of that town. For those workers who did not use the mails and wire transfers, earnings often moved back through these same circuits: the men who were working at factories handed off money to trusted kin and co-villagers who were still working in the maritime trade, and these earnings would be carried on the ships back to their families on the subcontinent. At the same time, men on incoming ships communicated news of family, friends, and ongoing events on the subcontinent to those who were living and working onshore in the United States. The waterfront, in other words, was the hinge between the onshore and 
maritime worlds. Indian men who were living onshore would visit the ships during the days they were lying in port, pass news, information, money, and other items to individual seamen whom they knew onboard, or in some cases helped these men to desert. The seamen onboard would pass information to their friends onshore and in some cases help these men find work on outgoing ships. ${ }^{92}$

For all the controls on their movement, for all the legal restrictions they faced, and for all the public outcry against their presence in the United States, Indian seamen used their networks to render the waterfront more permeable and the United States more navigable. The record of these men's lives is fragmentary; it exists in a scattering of archival documents and news reports and a handful of firsthand accounts. But, together, these sources make clear the varied makeup of Indian maritime workers' onshore worlds. These men clearly relied on one another; as Indian seamen deserted and found work in the United States, they fueled a chain migration in which they helped others from their families, villages, regions, and former ships desert and find work as well. However, this was only one part of the story. Indian seamen drew on the knowledge, assistance, and labor of many other people, from the American women of color a number of them married to waterfront shopkeepers, anticolonial exiles, and other sailors-Arab, Irish, and British. The spaces they inhabited and moved through were comprised of and animated by all these other people. ${ }^{93}$

The accounts of individual seamen make this clear. Dada Amir Haider Khan's desertion in January 1918 was striking for the variety of nonIndians who came to his aid. He and one of his shipmates were first encouraged to desert by the Jewish proprietor of a waterfront provisions store on Manhattan's West Side. While exploring the docks on a two-hour shore leave, Khan and his friend wandered into the shop, where "Mr. S. Doctor" put the idea into their heads of jumping ship, described the higher wages they could get working on U.S. ships, and coached them on what to do. One evening a few days later, Khan and his friend took shore leave again, "telling our shipmates we were going for a stroll," but they did not return. When they found themselves wandering the streets of Manhattan in the middle of a severe winter night, "wrapping ourselves in whatever we had-an old pair of pants, a cotton shirt and a 
coat, a cheap cap and a coloured piece of cloth for our heads," it was an African American boardinghouse keeper in the Tenderloin district along Seventh Avenue who ultimately took them in and helped them hide. "[M]y companion had a talk with the Negro landlady," Khan writes, "and explained to her that we had deserted a ship and did not want to return [and] it was necessary for us to remain indoors while the vessel was still in port, so that we would not be apprehended and taken back. [So s] he arranged for a young Negro girl who was living in a room on the same floor to [go] purchase our food [for us]-bread, butter, eggs etc. which she cooked for us in the house." After a few days in hiding, under the boardinghouse keeper's care, Khan and his shipmate returned to the shop on West Fourteenth Street, where Mr. Doctor exchanged their few remaining British pounds for dollars, advised that they remain near the waterfront in order to find work, and directed them to the Seamen's Institute, a sailors' boardinghouse nearby where they could stay cheaply for a longer stretch of time. Here, Khan and his friend told the man in charge that they had deserted their ship, and he took them in with no questions asked. ${ }^{94}$

At the Seamen's Institute, Khan and his friend met "a young Britisher" who helped them through the next step in their journey. The British sailor had also just jumped ship and explained to the Indians how "alien seamen," as a class distinct from "immigrants," could attempt to sidestep the bulk of U.S. immigration laws. After filing a petition of intention to naturalize, he told them, seamen could obtain the right to work on U.S. merchant ships, join U.S. maritime unions, and then apply for full U.S. citizenship after three years of work. While it ran counter to the recent laws of 1917, this provision provided a loophole through which Indian and Chinese seamen could enter the American merchant marine. Khan followed the steps as they were explained to him and succeeded in taking this path; within months of deserting his British steamship, he was working on U.S. ships at higher wages, with New York City as his home port. After Khan had spent almost a year sailing in and out of New York, it was finally an Arab sailor who connected him to the city's network of Indian ex-seaman. On the waterfront, Khan bumped into an "Arab coal-passer" with whom he had worked on a previous ship. This friend "had come into contact with some Indians and took me to meet 
them." Khan now found a community of "like-minded countrymen" in New York City but had arrived at this point through the assistance of a Jewish shopkeeper, an African American boardinghouse keeper, a white British sailor, and an Arab coal passer. ${ }^{95}$

The motivations of these men and women likely varied. While all four showed some sympathy for Khan, the shopkeeper, Mr. Doctor, was part of a complex dockside economy that depended on long-term relationships with seamen. In addition to supplying seafarers with provisions and clothing and helping them find work on the ships going in and out of port, Mr. Doctor operated an informal banking system in which seamen could save money between voyages. Khan and other sailors left considerable sums of money with him as deposits during the months they were away at sea and then drew on these sums when they were in port. This was a mutually beneficial structure; seamen were afforded the security of keeping their savings safe during their voyages, and, as Khan explains, "since everyone did not return or demand all their money at once, [Mr. Doctor] could make use of the deposits to finance his business operations." $" 96$ The African American boardinghouse keeper also derived some business from Khan and his friend in the first days they were onshore-like many single and widowed working-class women in the city, she took lodgers in order to support herself financially. Khan makes clear, however, that she took in the two bedraggled Indian men even when several other boardinghouse keepers would not, and took very little in exchange; he implies that her actions were motivated by something more-by an empathy or racial affinity that others he encountered did not have. ${ }^{97}$

As heterogeneous as his initial allies were, Dada Khan's subsequent experiences illuminate the ways that Indian ex-seamen in U.S. port cities were helping other men from the subcontinent gain greater power over their mobility, labor, and lives. After his chance meeting with the Arab coal passer, Khan became part of a predominantly Indian circle of "seafaring men" who moved through and congregated in a series of spaces in the blocks that extended inland from New York City's West Side waterfront. As one moved from the docks toward the center of Manhattan, the bustle and commerce of the waterfront-ships, barges, people, goods, trucks, trolleys, crates, and horses-gave way first to the 
poor and working-class Irish American neighborhood known as Hell's Kitchen and then to the crowded tenements and licit and illicit entertainments of the Tenderloin. At the turn of the century, the Tenderloin stretched from Twenty-Third to Fifty-Second Streets and Eighth to Fifth Avenues. Clubs, cafés, saloons, theaters, and burlesques were concentrated along and near the north-south-running avenues, while blocks of four- and five-story working-class residences ran in between, along the east-west-running streets. Working- and middle-class African Americans lived in concentrated pockets throughout the area, particularly in the corner of the neighborhood farther downtown and toward the river, where Indian seamen began to settle in the 1910s. Though by this time, the violence of white immigrants and New York City police had pushed much of the black population farther uptown to San Juan Hill and Harlem, and sections of the neighborhood's entertainments were evolving into a professionalized theater district, the lower Tenderloin was still a racially mixed part of the city with crowded tenements and a sizable transient population. ${ }^{98}$

It was here that a small population of Indian maritime deserters began to find rooms and open small-scale businesses. One of these was a laundry on West Twenty-Third Street run by two Punjabi ex-seamen, and another was a hole-in-the-wall Indian restaurant on West Thirty-Seventh Street, run by a Goanese man who was likely a former steamship cook. A little farther up the West Side at Forty-Third Street and Eighth Avenue was the Ceylon India Restaurant, run by K. Y. Kira, a Sinhalese former circus performer who appears to have taken in escaped seamen from Ceylon and elsewhere, providing them with short-term lodging above his establishment. In the restaurant itself, Indian seamen shared space with political exiles and students from the subcontinent, who had made the Ceylon India into a hub of expatriate nationalist activity. At Eighth Avenue and Forty-Seventh Street was a large single-room-occupancy hotel that, at least for a short time, became a kind of halfway house between the Indian maritime and onshore worlds. At the time of the 1930 census, the hotel was home to a population of more than fifty Indian men; a handful held jobs on steamships-as cooks, waiters, stewards, and seamen-while the others worked in similar capacities in restaurants in the city or supported themselves doing "odd jobs." Amir Haider 
Khan also helped open two businesses on the West Side. In late 1920 or early 1921, he invested much of his savings to help a Punjabi student open a restaurant around Seventh Avenue and Thirty-Eighth Street, which, though short-lived, became another space of gathering for the city's Indian seamen and students. Later, Khan partnered with another ex-sailor to open a laundry and dry-cleaner's shop in the basement of a residential tenement building on West Forty-Third Street. ${ }^{99}$

These small businesses played dual roles. They were commercial ventures, but they were also dynamic community spaces where Indian workers gathered daily to socialize and exchange news and information. The men who operated the laundry on Twenty-Third Street received an Urdu newspaper in the mail and so provided their countrymen in New York with access to detailed information about ongoing political events in India. The laundry and restaurants were also places where members of the seafarers' community could meet up and keep track of each other and they were hubs for finding either onshore or maritime work. One of Khan's extended voyages out of New York in 1919 came about after he met a Punjabi seaman "while dining at one of the Indian restaurants," who engaged Khan in conversation, asked if he was employed, and told him of a ship about to leave for Italy that was in need of a crew member with his skills. ${ }^{100}$

On at least one occasion, Dada Khan used his dry-cleaning shop to move seamen in the opposite direction, off the ships and into the city. In 1922, an acquaintance of Khan's, Abdul Rehman, was canvassing the waterfront, moving on and off various ships that were then in port, looking for work, when he met an older seaman who was asking after his nephew "Amir Haider." Rehman conveyed the news to Khan, who then visited his uncle's ship in port in Brooklyn. He wrote later that although "I was not well off financially at the time ... [I] asked him whether he wished to leave the ship at New York." At their request, Khan helped both his uncle and another shipmate desert, hiding them in a sleeping area at the back of the laundry, where "we served them their food until we could provide suitable clothes so that they could appear more presentable in the New York surroundings." Khan and his friends then found jobs for the men, who eventually moved on to live with a group of other ex-seamen elsewhere in the city. ${ }^{101}$ 
When an escaped seaman left the port city in which he had deserted and traveled farther away to one of the factory towns that were part of the Indian circuit, he depended on another set of contacts and relationships. On arrival at one of these destinations, he found a constellation of people and spaces similar to those he had encountered in the port city: boardinghouses, shared apartments, and private residences; boardinghouse keepers, middlemen, and other escaped seamen. By the 1920s, there were Indian ex-seamen who had settled in each of the major factory towns who could help the newly arrived. They fell roughly into two categories. One group had opened restaurants or were running boardinghouses and other small businesses. They could set up new arrivals with a place to stay, perhaps on credit to begin with, and direct them toward work. Their businesses were places where other ex-seamen congregated and where new arrivals may have met men whom they knew from maritime work or through family and kinship connections. This was especially the case in larger cities like Detroit. Another group who could assist newcomers consisted of those Indian ex-seafarers who had lived and worked in specific factory towns for extended periods of time - men who had gained a footing in these places and developed local knowledge and connections. Just as in New Orleans, a small number of these men had married local women of color. They and their wives could provide invaluable guidance and assistance for Indian deserters who were newly arrived.

In Detroit, a small number of Indians were among the groups of predominantly Muslim men-Afghans, Arabs, Turks - who turned a section of Black Bottom apartment buildings into makeshift rooming houses. During and immediately after the First World War, an increasing number of buildings along Monroe, Fort, Congress and Lafayette Streets were turned over to such use, becoming temporary homes for various transient populations of immigrants workers. By 1920, two Indian men who had entered the United States in the early 1910s, Idris Ali and Anoar Mohammed, were operating boardinghouses for other Indians in this area. On the day of the 1920 federal census, Ali was boarding twelve Indian men and Mohammed was boarding thirteen, all of whom worked on the auto assembly lines. In 1930, Wozid Ali was running a rooming house in the same area with fourteen Indian autoworkers as boarders, and a second Mr. Allie had a smaller apartment nearby where 
he was lodging five more men. By now, entire blocks in this part of Black Bottom were dominated by boardinghouses full of Muslim immigrant workers. Among them were dozens of Afghans - men who may have had a similar background to the Bengalis and Punjabis, as seamen who escaped British ships after sailing out of ports on the subcontinent. Two doors down from Wozid Ali was an Afghan named Chanan Din, who had entered the United States during World War I and was now boarding a dozen Afghan and Arab autoworkers. A block farther away, Jacob Khan, another Afghan, was boarding twenty-one. The Indian restaurant in this neighborhood could also act as a conduit for men who were new to the city; Indian seamen could come here in order to track down friends or acquaintances and be directed toward nearby rooming houses. An Indian seaman, newly arrived in Detroit from New York, Baltimore, or Philadelphia, had only to find his way to this part of Black Bottom and he would have been able to draw upon the local network here for food, lodging, and work. ${ }^{102}$

The Indian rooming houses here bore some resemblance to the boardinghouse that Alef Ally ran in New Orleans for members of the Hooghly peddler network, but they also differed from Alef Ally's in important respects. One of these was the relationship between boardinghouse keeper and boarders-and among the different men living together in a single boardinghouse at any given time. Most of the Bengali peddlers who were operating in New Orleans from the 1890 s to the 1910 s came from a small cluster of villages in the same district of West Bengal, and many appear to have been related to one another as uncles and nephews, fathers and sons, brothers and cousins. They also were working in a coordinated manner when they peddled their goods. The connections between seamen were less familial and the work they were doing onshore was more individuated. These men did share bonds of language, region, religion, and occupation, and individual crews were often recruited from a single village or locality. These bonds remained important within the onshore networks of maritime deserters, but the industry drew workers from multiple regions of the subcontinent, and onshore populations were varied and marked by much individual transience. Friends, co-villagers and shipmates spent intensive periods of time together at sea and onshore but often were 
separated from one another for months or even years at a time as the demands of maritime and factory work pulled them in different directions. ${ }^{103}$ So, while the Indian boardinghouse keepers in Detroit and elsewhere may have had sympathy for their boarders as countrymen and former seamen, the assistance they offered many of these men would no doubt have been of a different tenor than the assistance offered by senior to junior members of the Hooghly peddler network.

The structure of the boardinghouses was also such that even the most generous and helpful boardinghouse keeper had a relationship to his boarders that was, at the end of the day, financial. The men who ran these establishments were not property owners, but rather ex-seamen who had gathered enough resources to rent a large apartment building, convert it to use as a rooming house, and then sublet it to their boarders. The boardinghouse keepers were responsible at the end of each week or month to pay rent on the entire building-anywhere from $\$ 25$ to $\$ 125$, depending on its size-which they had to collect from their boarders. The proprietor of such a rooming house, then, would have been motivated at least in part by self-interest to help recently arrived ex-seamen find employment in the local factories.

Where such establishments resembled Alef Ally's was their dependence on the labor of local women-often women of color. Wherever they were, these boardinghouses required a considerable amount of daily upkeep. Someone needed to clean rooms, launder bed linens, and in some cases, prepare breakfasts and other meals for between ten and twenty men. Alef Ally engaged Celestine Gardner, an older African American woman, to do this work at 1428 St. Louis Street in New Orleans, and many of the boardinghouses in Black Bottom, Detroit-whether Indian, Afghan, Syrian, Turkish, or Greek-were structured in the same way. One woman often lived among all the male boarders and did the work of keeping up the house. In some cases, this was the wife of one of the autoworkers residing at a given rooming house; Wozid Ali's boardinghouse at 584 Fort Street, for example, was maintained by Marguerite Alli, the Mexican wife of one of the Indian lodgers at the address, and Jean Shah, the wife of one of Chanan Din's lodgers, may have played the same role at Din's rooming house. In other cases, Black Bottom's boardinghouse keepers hired single and widowed older women to live and work in their 
buildings; Sadie Abdou, a Syrian boardinghouse keeper at 556-56o East Lafayette Street, like Alef Ally, employed a widowed African American woman, Mary Stokes, to perform the daily labor of cooking, washing, and laundering. ${ }^{104}$

In addition to those men who ran businesses catering to Indian maritime workers in U.S. factory towns, there were certain members of the Indian population who simply took on the role of helping other seamen transition to life onshore. These were typically men who had been in the country for a longer stretch of time, had married and settled in U.S. port cities or industrial towns, had built up knowledge and language skills, and were more acculturated and integrated into local communities. These men were particularly important in towns with smaller numbers of Indian factory workers, where, instead of a structure of established Indian boardinghouses, the newly arrived seamen found informal networks of shared apartments and private homes. Mustafa "John" Ali came to play such a role in Chester, Pennsylvania, where, throughout the 1920 s and 1930s, the town's auto factory and shipbuilding yards drew small groups of Indian men who had jumped ship in Baltimore and Philadelphia. Ali's story parallels Haider Khan's in some respects: both men shifted in and out of maritime work and moved through multiple factory jobs; both became part of Indian communities in the gray areas of the immigration regime; and both aided other seamen to jump ship and work in the United States. While Haider Khan left the United States after seven years, eventually returning to the subcontinent, Ali married a local African American woman after jumping ship in Baltimore in the early 1920s, and he spent more than thirty years in the country before retiring and returning to his village in Sylhet. The majority of Indian men who deserted their ships to work in the United States in the 1910s, 1920s, and 1930s appear to have taken a path closer to Haider Khan's, but Ali was part of a smaller group who, after jumping ship, stayed in the United States for most or all of the rest of their lives. Like the Bengali peddlers who settled in New Orleans, these men helped anchor the broader network of escaped seamen in a series of key locations.

When John Ali moved to Chester, Pennsylvania, in the late 1930s, he had already been living in the United States for close to a decade, moving from one job to the next. He had learned English, in part by 
listening to the radio, and had worked in Baltimore, Buffalo, and, for a brief time once before, in Chester itself. Chester was a city dominated by industry. Its Sun Shipbuilding plant, which took up almost sixty acres along the banks of the Delaware River, was the largest of its kind in the United States, employing tens of thousands of workers-white, black, immigrant and U.S.-born-while a series of other factories were interspersed through other parts of the town. Indian ex-seamen had been working in Chester since the First World War, so when John Ali returned there, he joined a well-entrenched community that included one of his cousins, Nickar Ali. ${ }^{105}$ Because of his language skills, local knowledge, and acculturation, and presumably because of the experience and connections he had built in several other industrial towns in the Midwest, John Ali became a leader among Chester's group of Indian workers. He was in constant contact with the members of this community; the men regularly came to his house after work and on weekends to meet, talk, play cards, and listen to the radio together. According to John Ali Jr., his father always had a big pot of rice and curry on the back burner of their stove in order to feed the visitors who inevitably dropped by. He had learned to season his fish, shrimp, and beef with curry powder, paprika, and whatever other spices were available in the local stores. Ali translated news broadcasts for his visitors, from English into Bengali, as they sat in his home. "India was in the news a lot those days," says John Ali Jr., and his father's friends would gather to hear about the latest developments in the independence struggle, which he would translate as the broadcasts ran, and which they would all then discuss afterward. ${ }^{106}$

Ali also became one of the people whom newly arrived deserters sought out for help. Local officials eventually learned that he was playing this role-feeding and guiding the Indian seamen who came to see him-so when a ship in port in Baltimore or Philadelphia reported that members of their Indian crew had jumped, immigration officers often turned up at Ali's door. According to John Jr., two of the officers used to occupy the Alis' house on such days. They would invite themselves in and wait for half the day for the escaped seamen to arrive. "They would come around," remembers Ali, "and I'll never forget they would sit down and they would eat sardines out of cans-with a suit and tie on, they would sit at our dining room table and eat sardines while they waited for 
these fellows who jumped ship to contact my father." It was perhaps a sign of how effective the local network was that none of the Indian deserters ever showed up at John Ali's house when the immigration officers were in. "The word must have got out," remembers his son. ${ }^{107}$

John Ali Sr. and other ex-seamen like him managed to stay in the United States because of a three-year statute of limitations on their desertions. If these men jumped ship in the United States and managed to evade capture for three years, the immigration authorities could no longer arrest and deport them; they could stay in the United States. ${ }^{108}$ But these men were not welcomed as other immigrants might have been; they had no legal footing in the country and lived for years in this marginal status. Yet they did find homes and build communities-largely because they joined and were accepted by others on the nation's margins. John Ali and other Indian Muslim men simultaneously integrated into working-class families and neighborhoods of color in U.S. cities and built pockets of Indian community within those spaces. In fact, the latter phenomenon depended on the former. While localized Indian networks in places like Chester supported and sustained an ongoing flow of deserters from British ships, these networks were themselves made possible by Indian intermarriage within African American and other communities of color, and, more broadly, by these communities' acceptance of Indian and other immigrant men of color into their fold.

John Ali's trajectory illustrates these intertwined dynamics. Soon after Ali jumped ship for the second time in Baltimore, he met a young African American woman from the city, Mamie Chase, at a class he was taking at a local school. The two courted, married, and over the next few years had three children together. Although John Ali moved in and out of his family's life over the next several years as he went off in search of industrial work, his son, John Ali Jr., recalls that both his mother's family and the larger West Baltimore neighborhood in which they lived provided a home for his father. Ali developed a close relationship to his mother-in-law, Mamie's mother-who John Jr. remembers loved to dance with the young Bengali whenever he was visiting the family_and with Mamie's older brother, with whom he used to share drinks at the local Elk's Lodge. The neighborhood along Pennsylvania Avenue in which Mamie's family lived and where John Sr. and other escaped Indian seamen settled was the 
cultural heart of Baltimore's African American community, but at the same time, a wide variety of immigrants had settled among the black population: Filipinos, Portuguese, Chinese, and Roma, among others. Sometime in the 1930s, another Bengali ex-seaman named Ali opened an Indian restaurant here along the same stretch of Pennsylvania Avenue that included the Royal Theater, Baltimore's equivalent of Harlem's Apollo, and the other black nightclubs and movie houses that were the life of the district. It was in this part of Baltimore that John Ali Sr. first gained his footing in the United States, learned English, and built local relationships, all of which eventually enabled him to help others in the Indian worker community when he moved with Mamie and his children to Chester. ${ }^{109}$

In both Baltimore and Chester, John Ali and his Indian contemporaries stepped into a United States that was defined by the color line, and it appears to have become clear to them and to those around them which side of the line they were on. Although Chester, Pennsylvania, was technically in the North, in the 1930s, its neighborhoods full of industrial workers as well as its theaters, primary schools, and public facilities were all racially segregated. As in Baltimore, Indian and other immigrant men of color lived in black neighborhoods, and the lines that separated these neighborhoods from white ones, remembers John Ali Jr., were clearly enforced, particularly by members of Chester's Italian and Italian American population. In Chester's main movie theater, African Americans were seated on the left side of the house, while whites were seated in the middle and on the right. "When the center and the right became full," says John Ali Jr., the manager "would move the minorities from the left-hand side into the back and let the whites come over and sit in front of them." When the Indian men went to see a movie, "they would sit on the same side as the black people sat, because as far as the white people were concerned, they were doing it based on color." The same division held for those Indian ex-seamen who managed to save enough to open small businesses. As was the case in New Orleans, these men set up in black neighborhoods and became part of these areas' commercial and cultural landscapes. This was true for one of John Ali's circle in Chester, who left industrial work to run the main grocery and 
bar in a small, semirural, and predominantly black neighborhood in Chestertown, Maryland, seventy miles away. ${ }^{110}$

\section{"Indian Sailors Strike for Grub"}

In 1925, around the time Amir Haider Khan was leaving the United States and Mustafa "John" Ali was arriving, the Baltimore Afro-American, one of the county's national black weeklies, ran a banner headline across the top of page 9 about a group of Indian seamen who had arrived in port in Baltimore. In some ways, the article resembled those stories about "curious lascars" that had run in more mainstream U.S. newspapers at the turn of the century, and continued to appear in those papers even in the 1920s. The Afro-American's article, for example, spoke of a "mutiny" on the high seas; it focused in on one of the Indian men's "peculiar red whiskers" (presumably his beard, died with henna) and mentioned that the men would not eat food "prepared by unbelievers." But the similarities ended there. The main point of the article was in fact to explain how a group of Indian seamen now under arrest in Baltimore had come to the verge of attacking their employer. It described the men's poor working conditions on their ship and detailed their mistreatment at the hands of the ship's officers. It explained that the captain had refused to provide them with food prepared according to the tenets of their "Mohammedan faith" and highlighted the stand they took midvoyage by refusing to work. The Afro-American dispatched a reporter to speak not to the ship's captain, but to the arrested men, to hear their story in their own words. The paper also sent a photographer, so they could show their readership the six sailors who stood up for their rights on board. The headline that ran in bold letters across the full length of one page of the newspaper spoke of the "alleged" mutiny of these men, and the subheads fleshed out the details: "India Seamen Arrested; Tell Harrowing Tale-Five Dollars Monthly Wage and Meatless Diet Caused Near Mutiny on ShipBrutality and Hard Life of Jack London Stories Are Recalled at Police Station." Above the photograph of the six men, displayed prominently at the top of the page, was the heading: "East Indian Sailors Strike for Grub." Just below, the photo caption indicated one man among the 
Indians who was more likely of Somali or North African descent and pointed out that he was "undoubtedly of African parentage."111

In its important respects, the Afro-American's article could not have been more different from those of the era's white-owned papers. The six seamen were presented here as human beings and, specifically, as workers of color, whose stories were important and whose actions were logical, reasonable, and even commendable. Their dietary observances were not the focus of ridicule or voyeurism but were rather aspects of their faith that their captain was wrong to deny them. Just as Mamie Chase's family and others on Baltimore's African American Westside welcomed Indian men into their families and communities-men who had otherwise been rendered "illegal" by the nation's racialized immigration regime-this black newspaper embraced a group of Indian seamen who had struck against an injustice and ended up in a Baltimore jail. Their story would have resonated with the others that filled the Afro-American's pages every week, of African American women and men subjected to the violence and injustice of white supremacy and criminalized for fighting back. The affinity that the Afro-American showed for these Indian "mutineers" was not isolated; this was a historical moment in which African American and Indian nationalist leaders were coming to recognize and articulate the connections between their struggles. ${ }^{112}$ Maritime desertion, however, led to its own arena of contact between the two groups, and as the story of Dada Amir Haider Khan makes clear, that arena could produce its own understandings and transformations. 

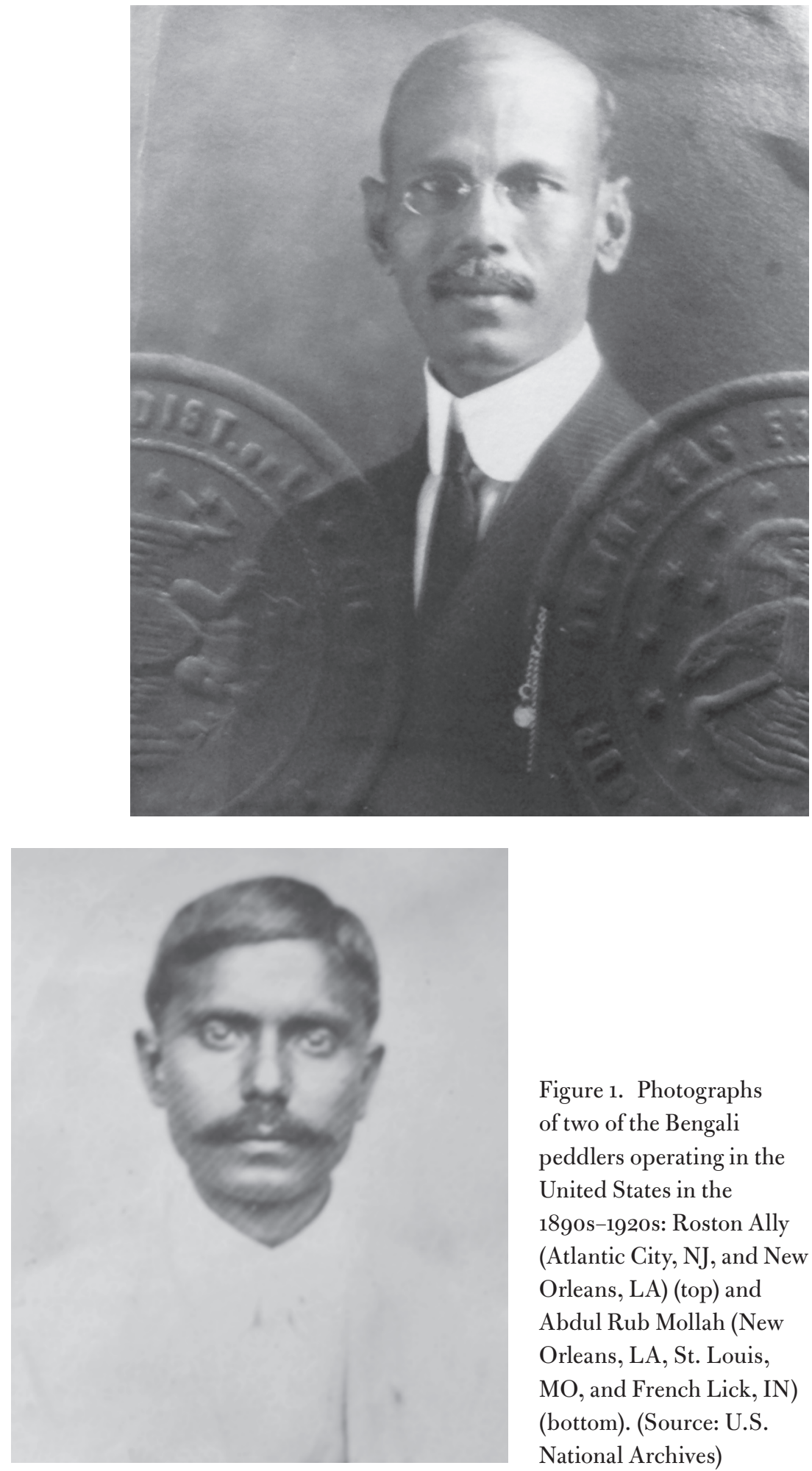

Figure 1. Photographs

of two of the Bengali peddlers operating in the United States in the 1890s-1920s: Roston Ally (Atlantic City, NJ, and New Orleans, LA) (top) and Abdul Rub Mollah (New Orleans, LA, St. Louis, MO, and French Lick, IN) (bottom). (Source: U.S.

National Archives) 


\section{LIST OR MANIFEST OF WLIEN IMMIGRANTS}

Required by the regulations of the Secretary of the Treasury of the United States, under Act of Congress appre

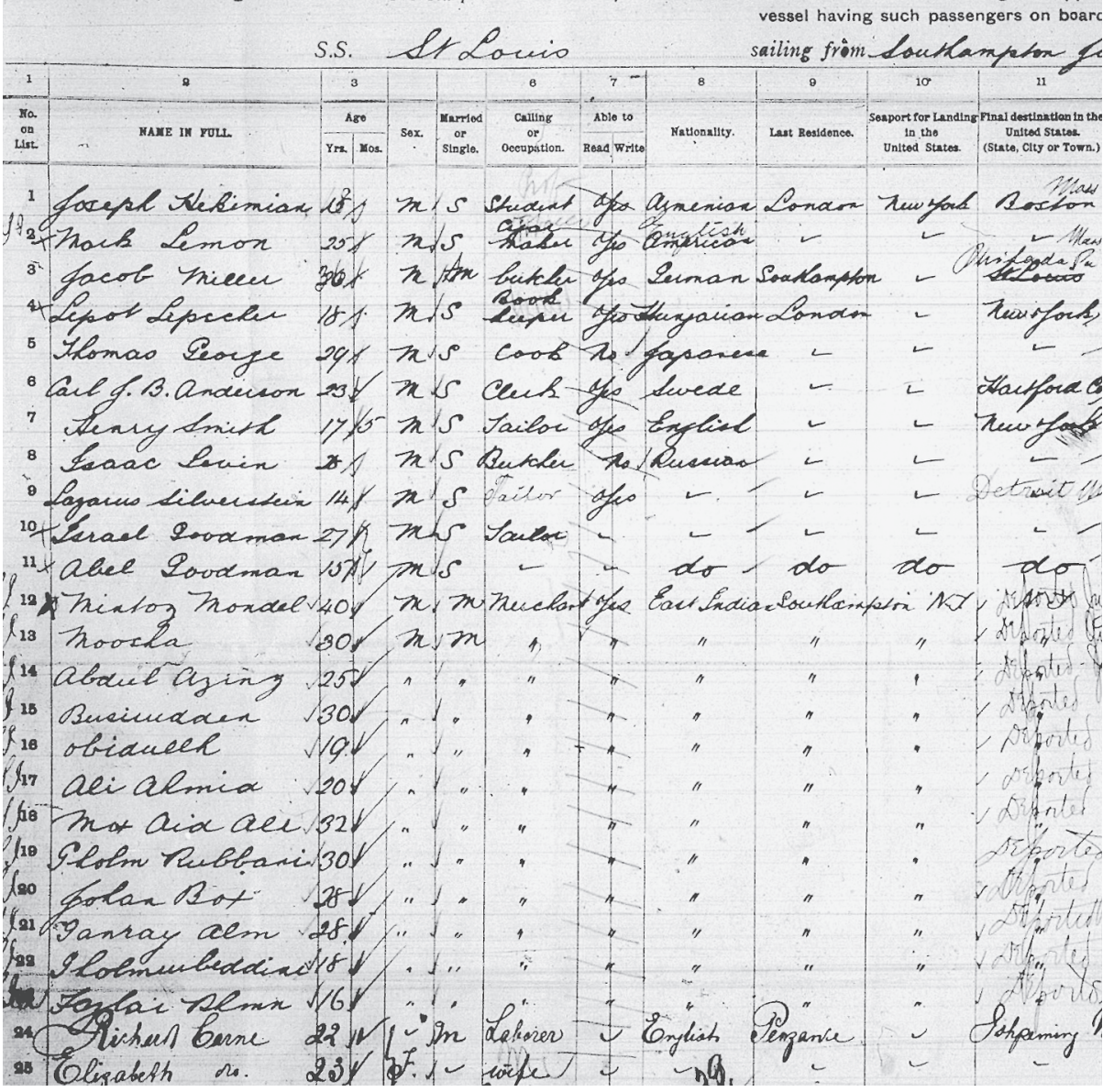

Figure 2. Detail of ship manifest for the American Line's SS St. Louis, which arrived in New York on June 18, 1897, carrying twelve members of the Hooghly peddler network who were on their way to sell goods on the boardwalks of New Jersey. The twelve were detained and then deported for violation of the Alien Contract Labor Law. (Source: U.S. National Archives) 


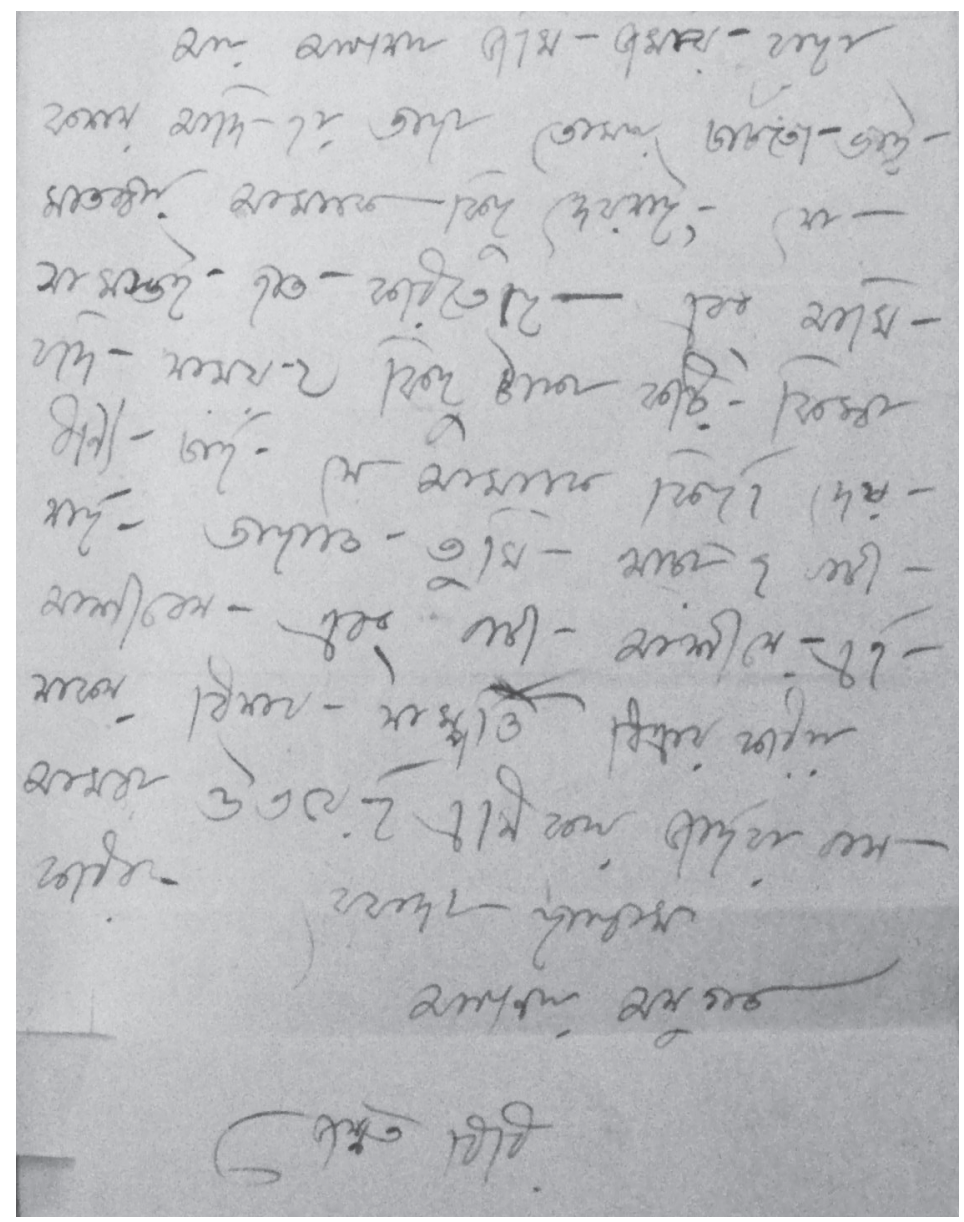

Figure 3. Detail of a letter sent from Jennat Bibi in West Bengal to her husband, Roston Ally, in New Orleans, asking that he return. (Source: U.S. National Archives). 


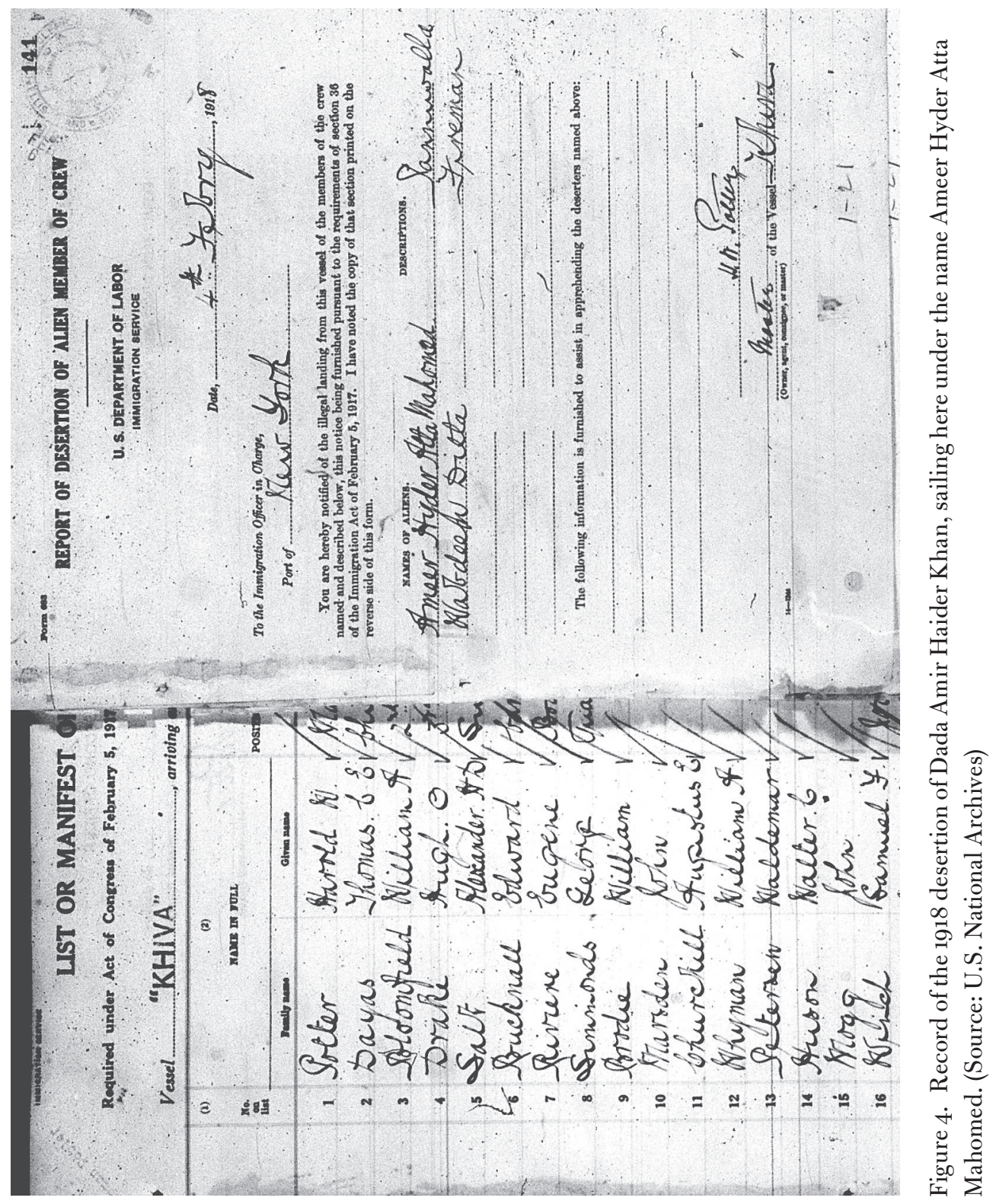




\section{SLOGAN OF ISLAM TO MINGLE WITH CHRISTMAS CAROLINGS}

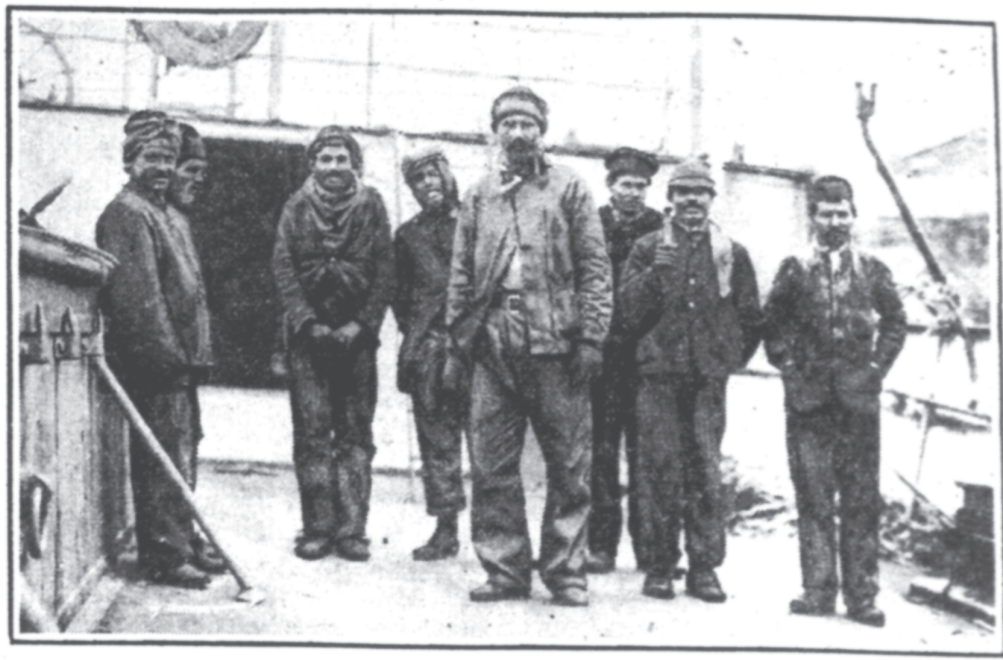

"SERANG" AND GROUP OF LASCARS

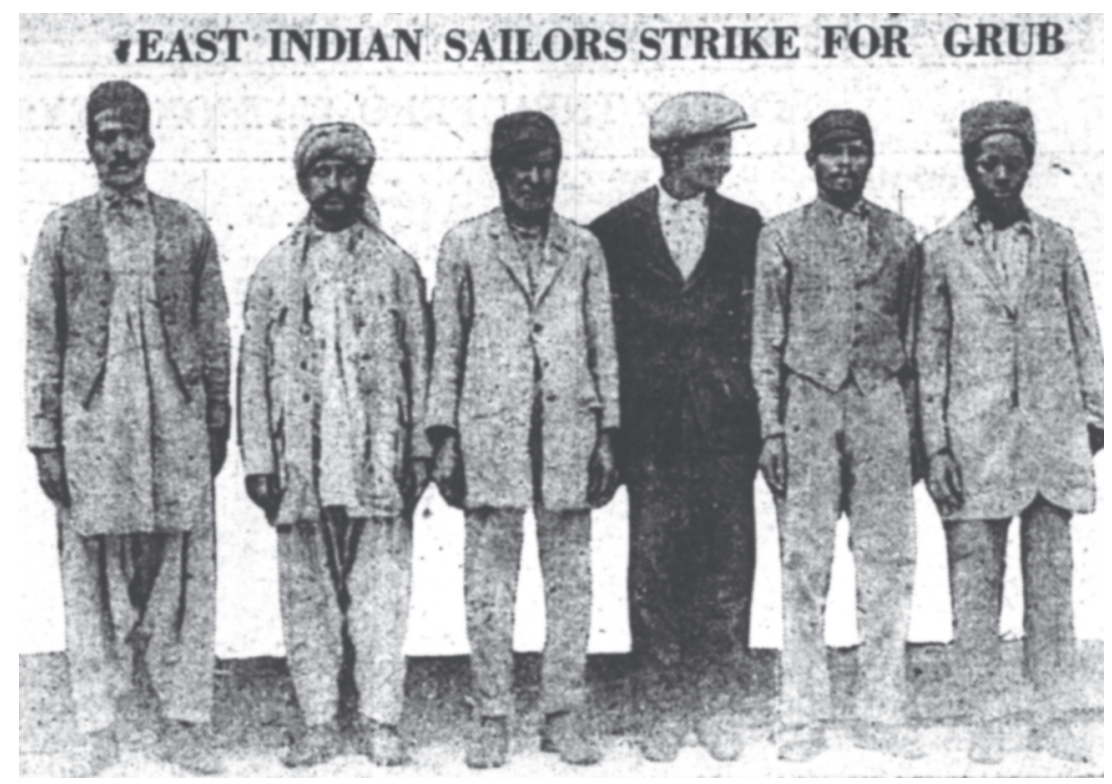

Figures 5 and 6. Images of Indian seamen from U.S. newspapers.

Top: Philadelphia Inquirer, December 25, 1903. Bottom: Baltimore Afro-American, August 1, 1925. (Source: Philadelphia Inquirer; Afro-American Newspapers Archives and Research Center, Johns Hopkins University) 


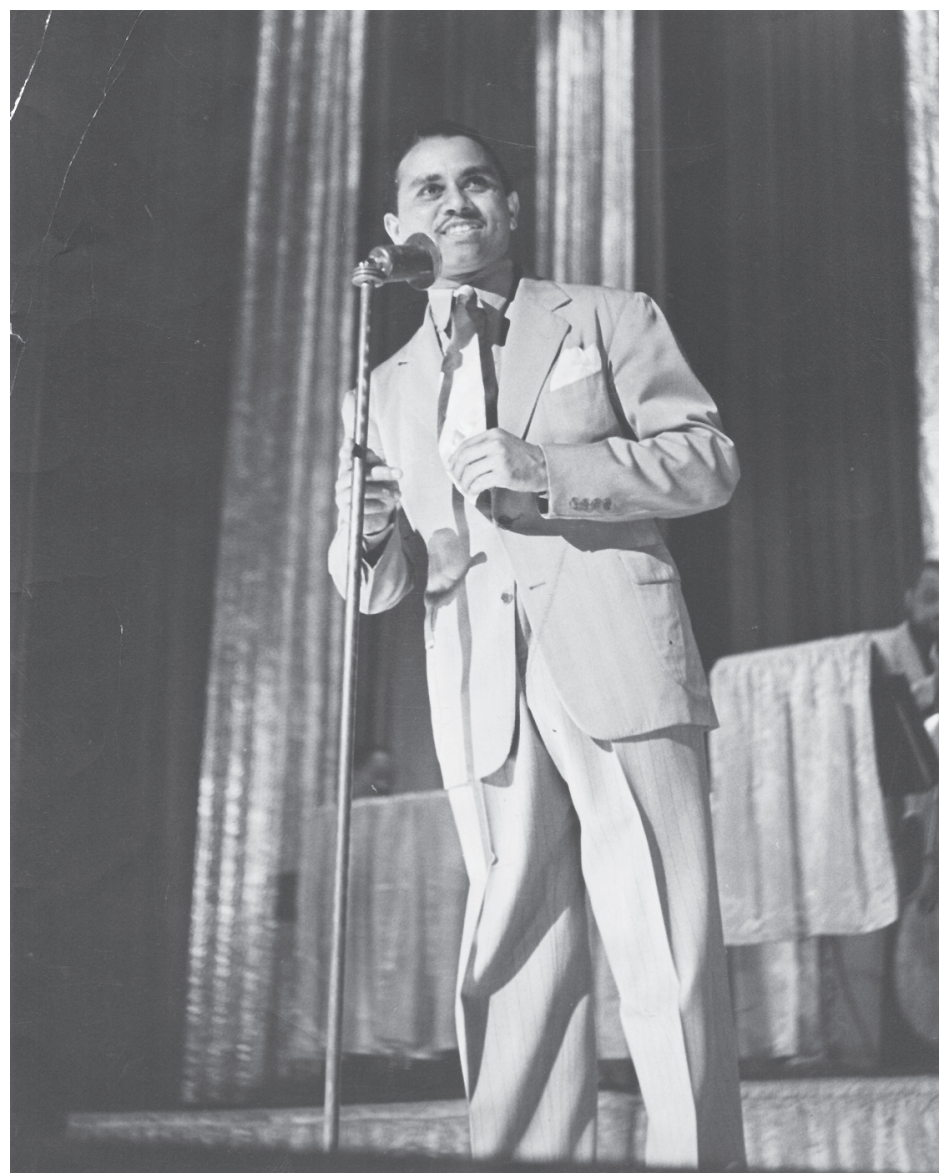

Figure 7. Bardu Ali, one of the first children of Bengali-African American intermixture in New Orleans, who went on to work as a dancer on the black vaudeville circuit in the 1920s; became emcee for Harlem's famed Chick Webb Orchestra in the 1930s, and then teamed up with Johnny Otis to open the Barrelhouse Club in Los Angeles in the 1940s. (Source: Afro-American Newspapers Archives and Research Center, Johns Hopkins University) 


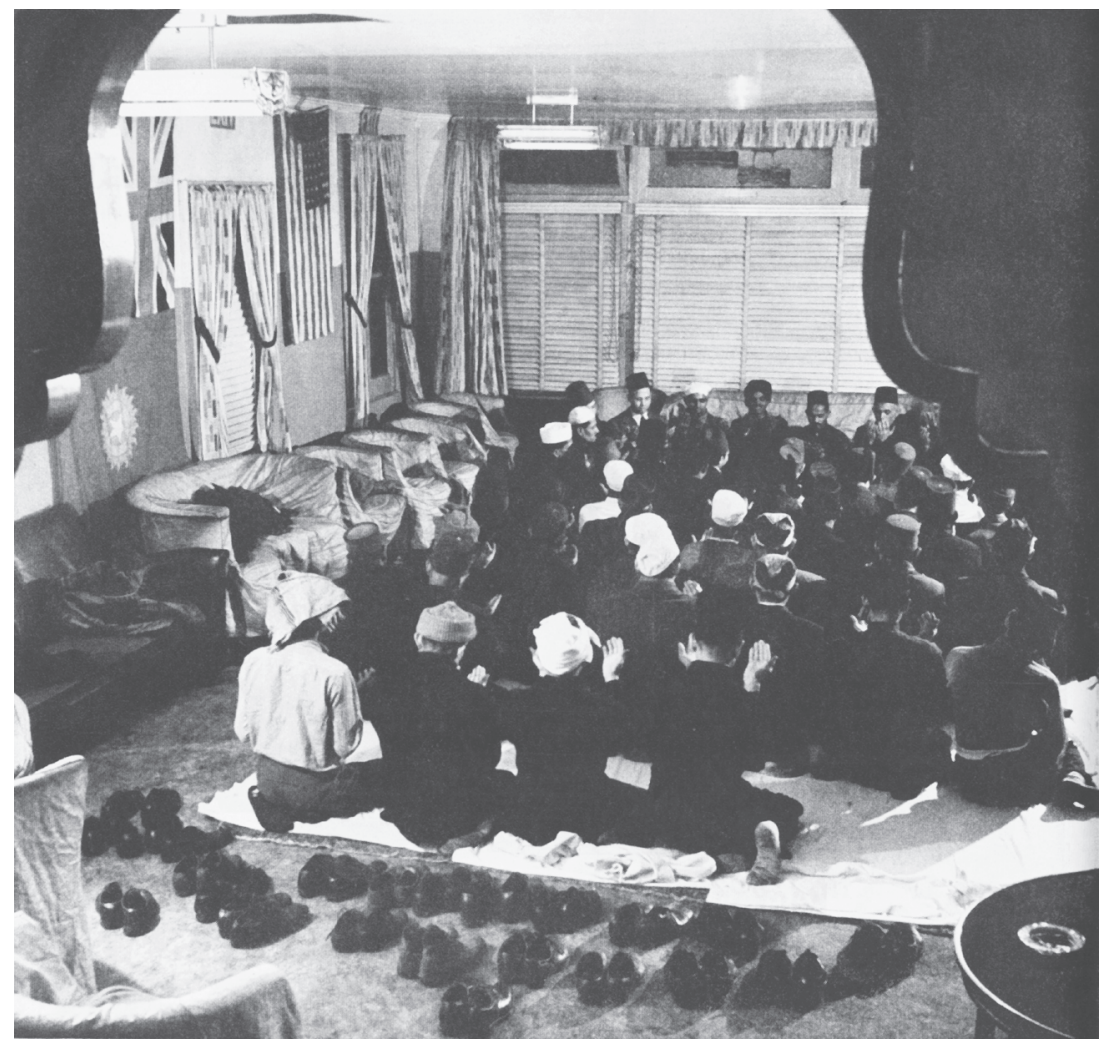

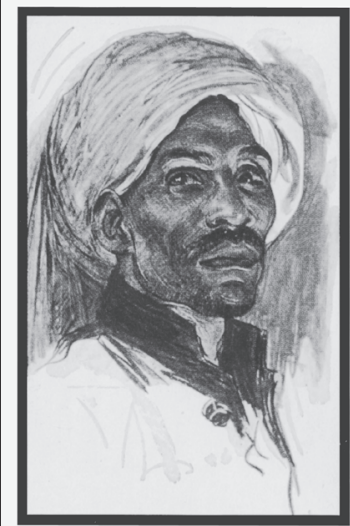

\section{NANOO MEAH}

Thin and malarial, he has spent 27 years at sea, is a boatswain. He has been in one sh p sunk by bombing. another in a convoy collision. He comes from Purangao near Calcutta in Bengal, where famine has been stalking the fields. Like all others here, he has afraid of Hindu inter

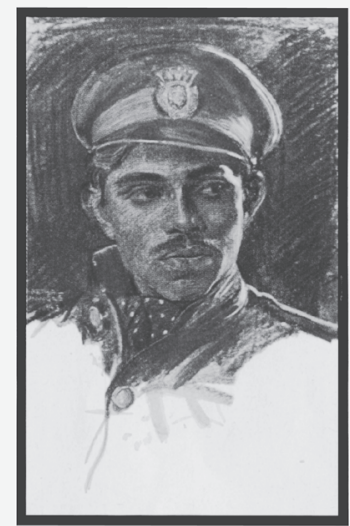

\section{ABDULL KARIM}

Weighing 90 pounds and only 19 years old, he is one of the best-educated men shown here. He went to high school and speaks English carefully and well. He comes from Ballygunge near Calcutta and is a steward. One Lascar as frail as Karim was one of two surat sea for two years and he wants to fly an airplane.

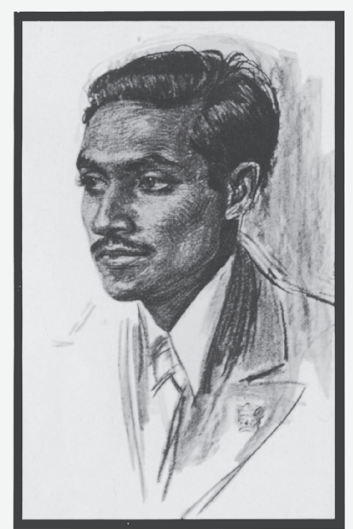

\section{NOJIBUL HAQUE}

Tense, excitable and 21, Nojibul Haque has also received some education, in Calcutta. He has been at sea two years as a messboy. He shows the glistening tice British at view is not typiet of young intello tue $\mathrm{Mos}$.

Figures 8 and 9. Images from the British Merchant Sailors Club for Indian Seamen, run by Ibrahim Choudry during World War II on Thirty-Eighth Street in midtown Manhattan. In 1944, Life magazine ran a feature about the club that included profiles of Indian seamen then in port. Top: the club's prayer room (Choudry is second from left, front row, facing camera); bottom: three of the men featured in Life. (Photo: Nelson Morris, illustrations: Martha Sawyers, source: Life Magazine) 


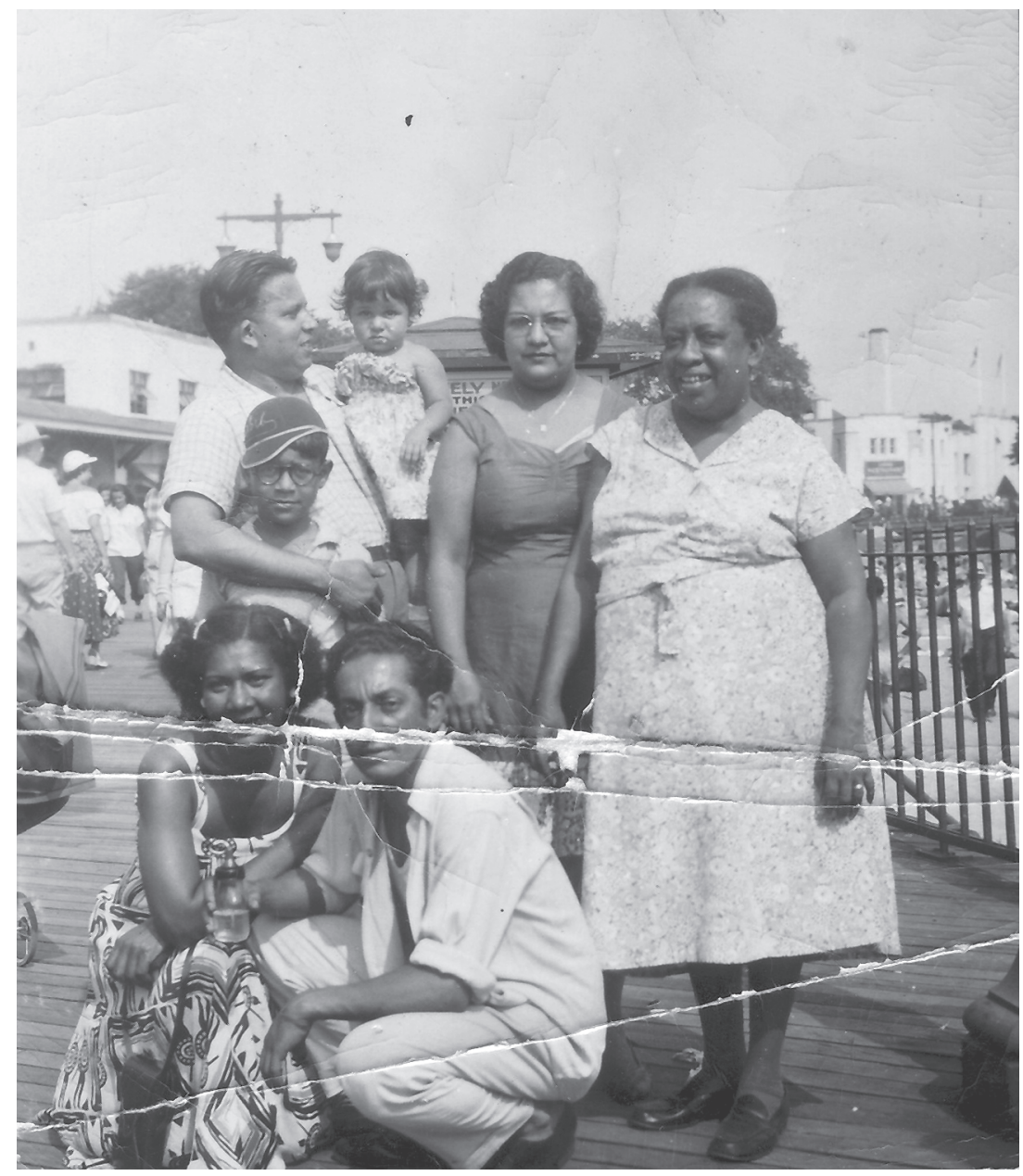

Figure 10. Habib and Victoria Ullah (back row, left and middle) with their children, Habib Jr. and Humaira, and friends, Doña Juana (standing, right), Fina, and Feyo (kneeling, left and right), at Orchard Beach in the Bronx, New York, circa 1950. (Source: Habib Ullah Jr.) 


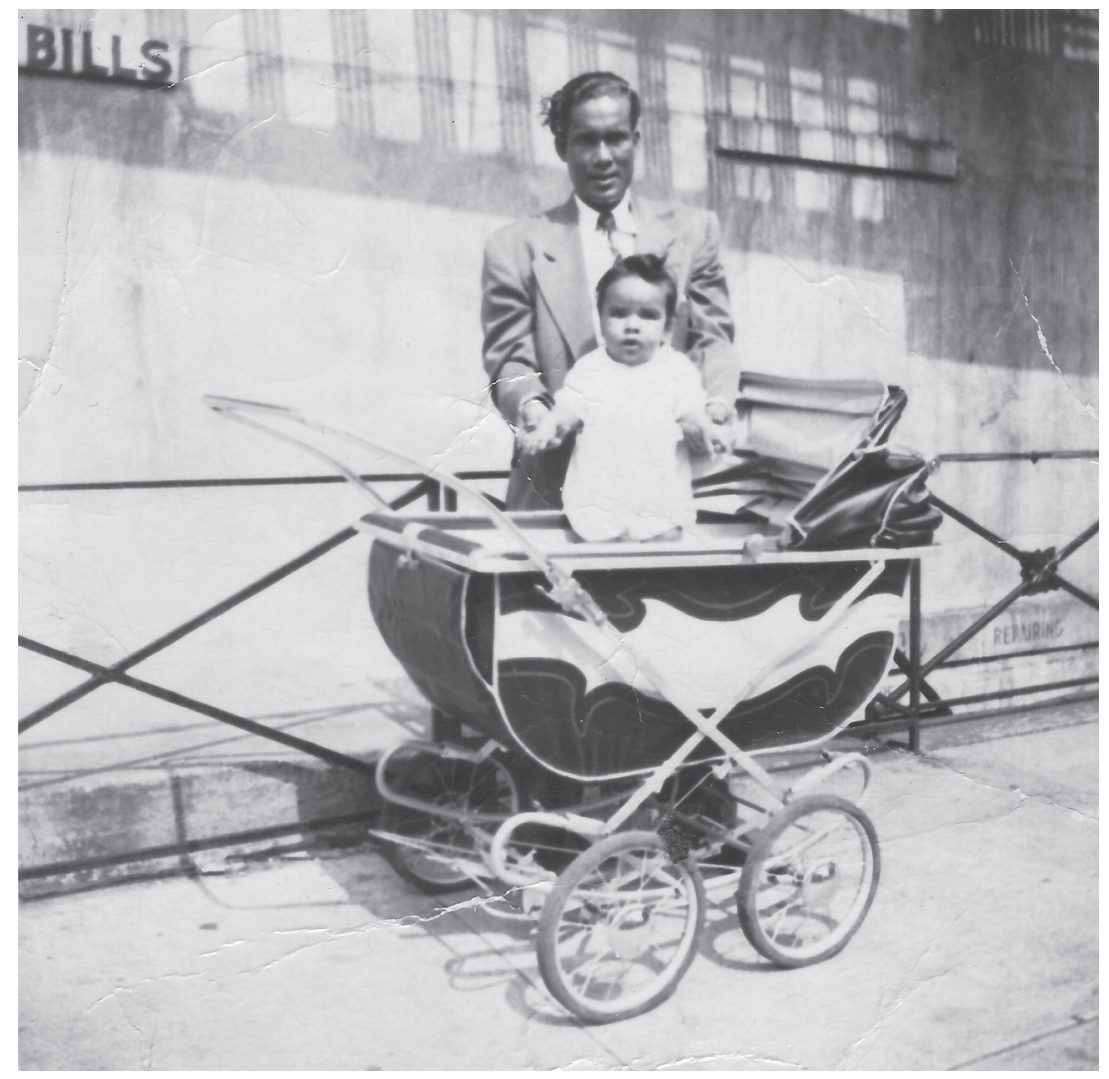

Figure 11. Saad "Victor" Ullah and his son, Victor Jr., late 1950s. (Source: Helen Ullah)

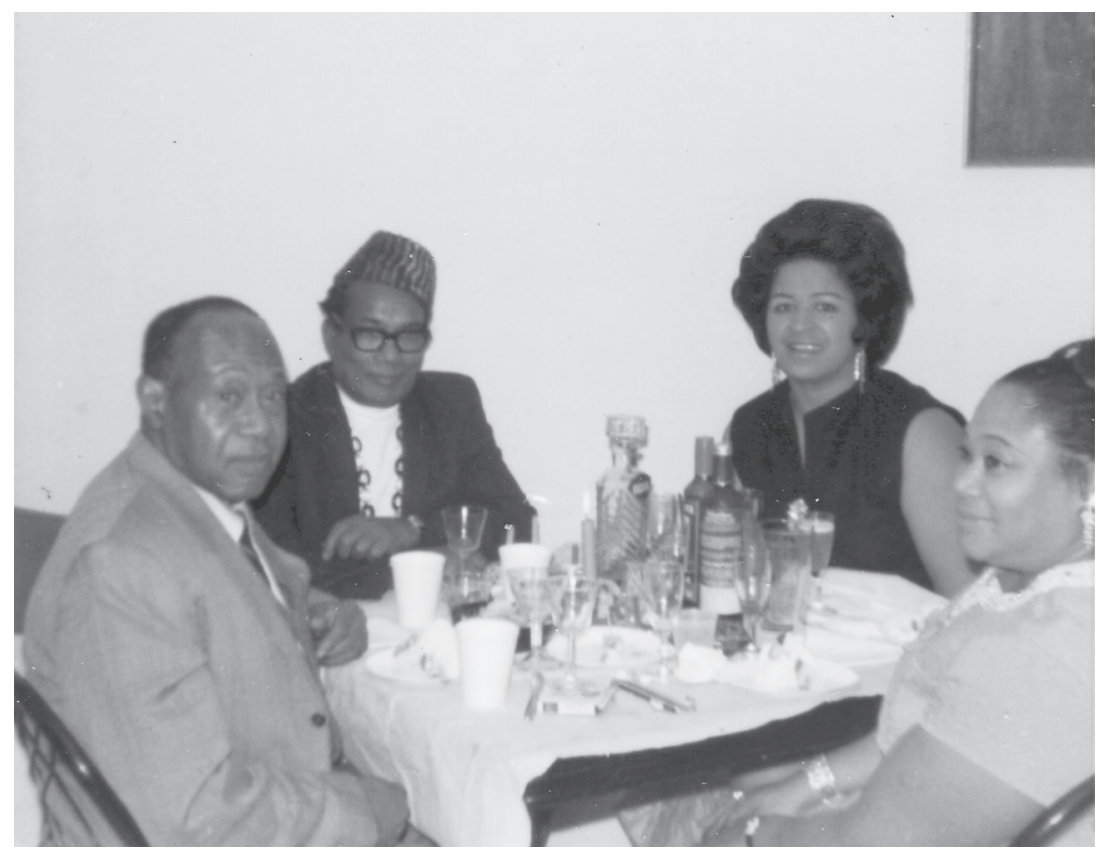

Figure 12. Saad (back left) and Helen Ullah (back right) with friends, circa 1964. (Source: Helen Ullah) 


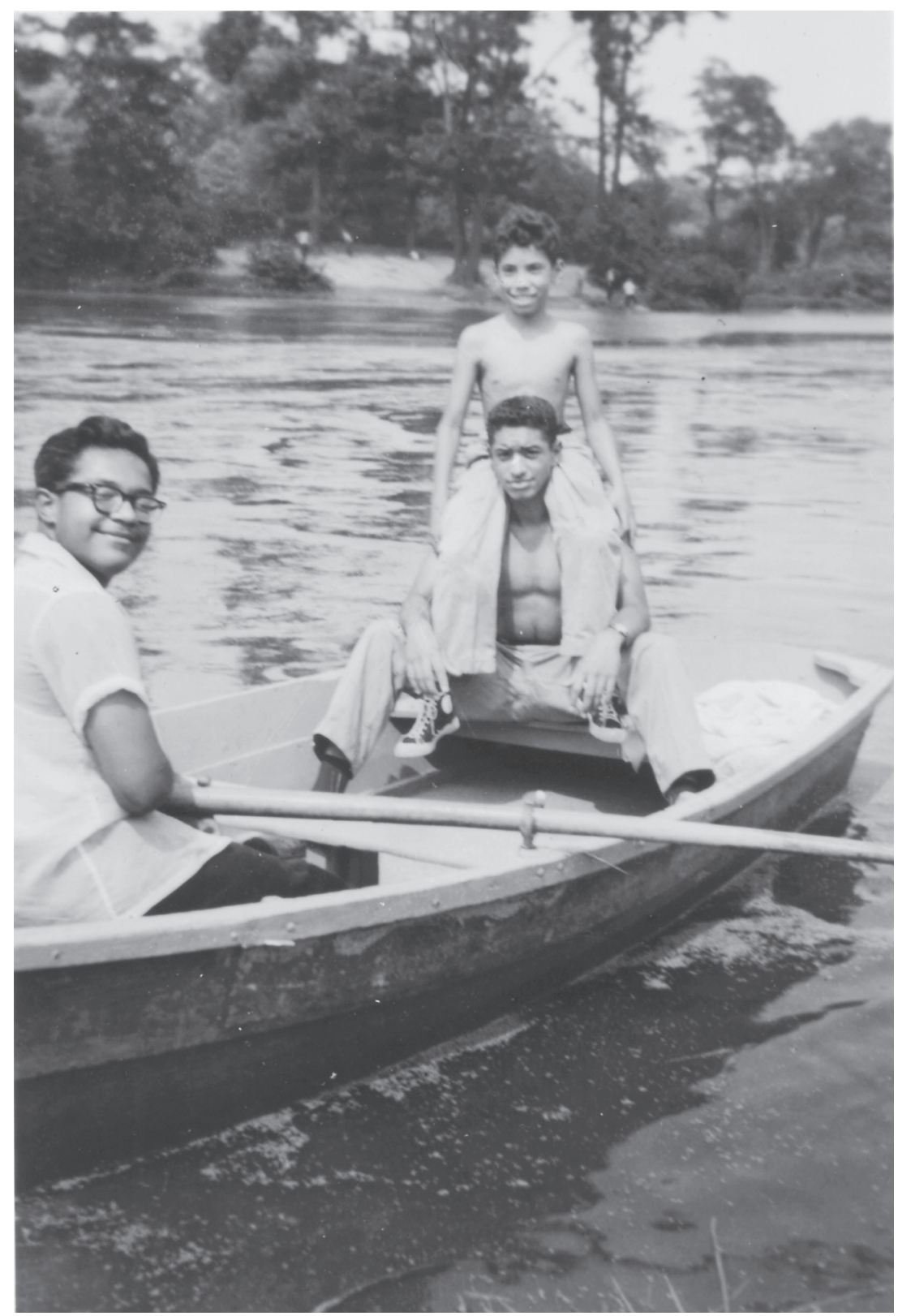

Figure 13. Habib Ullah Jr. (foreground) with two of his cousins, Ralph (top) and Martin (bottom) Caballero, on the lake at the northeastern corner of Central Park in Manhattan, late 1950s. (Source: Rafael Caballero Jr.) 


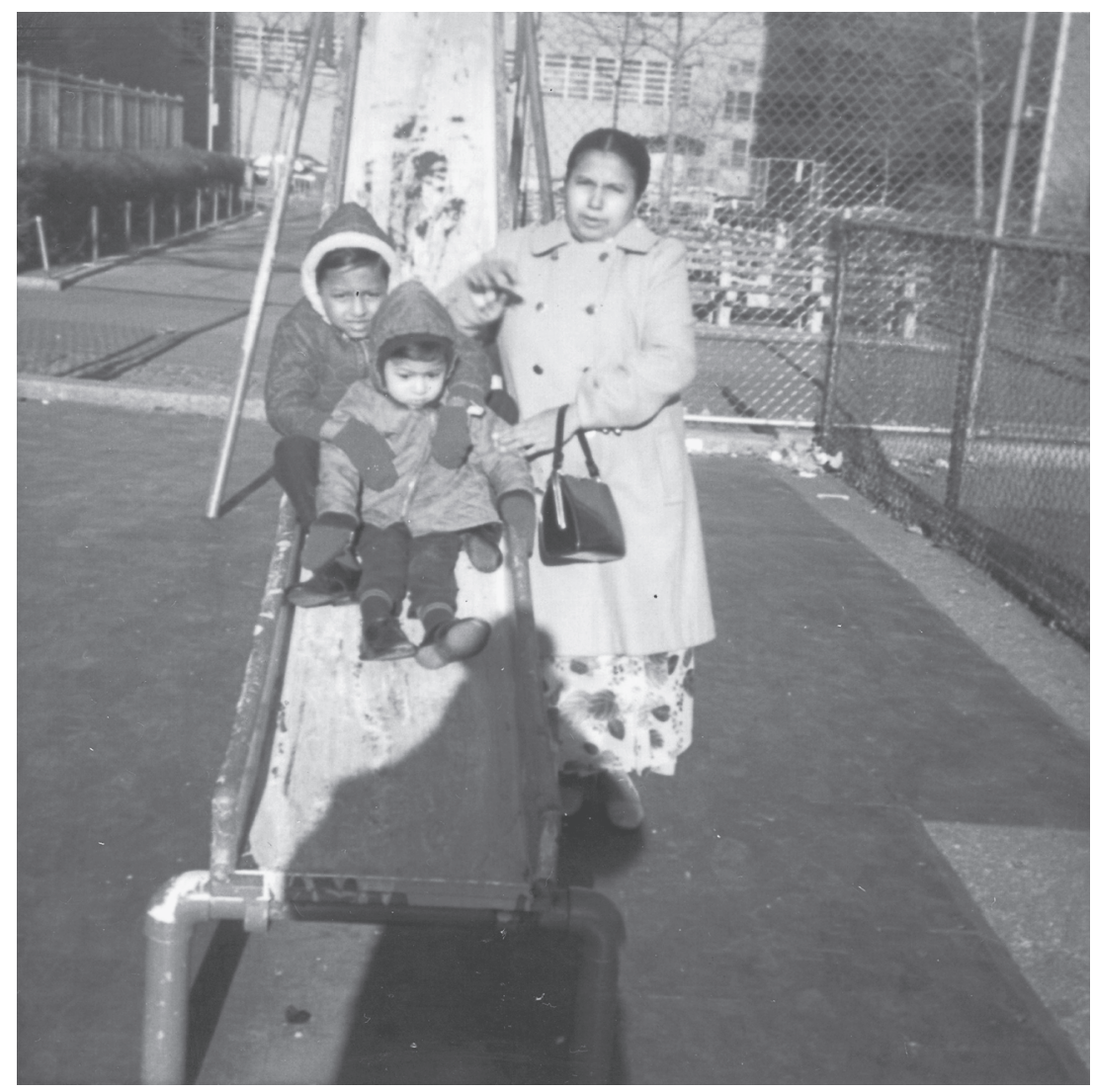

Figure 14. Moheama Ullah (Habib Ullah Sr.'s second wife) with her sons Alaudin (front) and Karim (rear) in the playground at the George Washington Carver Housing Project, East Harlem, circa 1973. (Source: Alaudin Ullah) 
